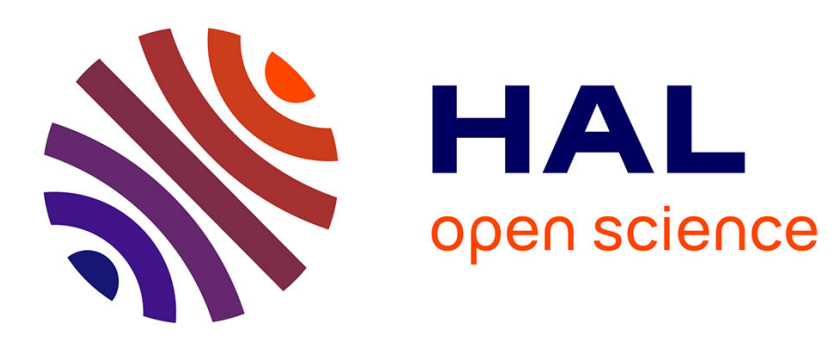

\title{
Economic liberalization with rising segmentation in China's urban labor market
}

Sylvie Démurger, Martin Fournier, Shi Li, Zhong Wei

\section{To cite this version:}

Sylvie Démurger, Martin Fournier, Shi Li, Zhong Wei. Economic liberalization with rising segmentation in China's urban labor market. Comparative Studies, 2008, 35 (Mars), pp. 13-26. halshs00353336

\section{HAL Id: halshs-00353336 \\ https://shs.hal.science/halshs-00353336}

Submitted on 6 Apr 2009

HAL is a multi-disciplinary open access archive for the deposit and dissemination of scientific research documents, whether they are published or not. The documents may come from teaching and research institutions in France or abroad, or from public or private research centers.
L'archive ouverte pluridisciplinaire HAL, est destinée au dépôt et à la diffusion de documents scientifiques de niveau recherche, publiés ou non, émanant des établissements d'enseignement et de recherche français ou étrangers, des laboratoires publics ou privés. 
Economic Liberalization with Rising Segmentation in China's Urban Labor Market*

\section{Sylvie Démurger}

University of Lyon; CNRS, UMR 5824, GATE

93, chemin des Mouilles

F-69131 Ecully Cedex

demurger@gate.cnrs.fr

\section{Martin Fournier}

University of Lyon; CNRS, UMR 5824, GATE

fournier@gate.cnrs.fr

\section{Li Shi}

School of Economics and Business, Beijing Normal University

lishi89@263.net

\section{Wei Zhong}

Institute of Economics, Chinese Academy of Social Sciences, Beijing wei_zhong@cass.org.cn

Key words: labor market, earnings differentials, segmentation, China.

JEL classification: J31, J41, P23, O53

\footnotetext{
* Paper presented at the Asian Economic Panel meeting held in Seoul (20-21 March 2006).

The authors are grateful to discussants and participants for helpful comments.
} 


\begin{abstract}
The massive downsizing of the state-owned sector and the concomitant impressive growth of the private sector at the end of the 1990s have altered the nature of the Chinese labor market. The introduction of market mechanisms has contributed to increasing labor turnover and competitiveness in market wages. Using two urban household surveys for 1995 and 2002, this paper analyzes the evolution of labor market segmentation in urban China, by applying an extended version of OaxacaBlinder decomposition methods. During the 7-year period, the sharp increase in real earnings for all workers shows substantial differences across ownership, economic sectors, and regions. We find strong evidence of a multi-tiered labor market along these three major lines and highlight increasing segmentation within each of the three dimensions, the gap between the privileged segments of the labor market and the most competitive segments widening over time.
\end{abstract}

\title{
1. Introduction
}

Since the launching of the policy of reform and opening-up in the late 1970s, both rural and urban labor markets in China have changed dramatically. By allowing market mechanisms to play a greater role in wage-settings and labor mobility to reappear, economic liberalization has revived incentive mechanisms and improved the efficiency of labor allocation across sectors, enterprises, and regions ${ }^{1}$. Despite the loosening enforcement of the hukou system ${ }^{2}$ that seriously impedes rural-urban migration, rural and urban labor markets remain highly segmented. Within both urban and rural labor markets, various rigidities also remain and reforms are still uneven and incomplete. In particular, restrictions on labor mobility across sectors and ownership in the urban labor market have remained quite strong until the mid-1990s (Knight and Song 1995; Zhao 2002; Chen et al.2005).

\footnotetext{
${ }^{1}$ The labor mobility from agricultural to non-agricultural sectors has been pointed out as a significant source of economic growth in China since the beginning of the reforms (Cai (2005)).

${ }^{2}$ The household registration system (hukou system) was established in 1958 to restrict migrations both between rural and urban areas and across regions. The main institutional barrier to mobility was the exclusion of rural residents from the urban welfare system then established, which provided housing, medical care, education, childcare, and pension to urban residents (Cheng and Selder (1994)).
} 
Labor market segmentation arises when labor market is made up of several segments with distinct rules for wage determination and a limited mobility of labor between segments. In China, where the so-called "iron rice bowl” of lifetime employment in state-owned enterprises was the norm until it was completely dismantled in 1994 (Knight and Song 2005), the issue of the public sector efficiency may be of special importance. A multi-tiered labor market in which wages are not only determined by skill differentials, but also by different institutional arrangements may have strong implications in terms of both labor allocation across sectors and income distribution among workers. In the case of China, Zhao (2002) and Chen et al. (2005) found that the payment of high non-wage benefits in state-owned enterprises prevented labor from moving out of the state sector in the mid-1990s.

Urban employment in China has increased from 95 million in 1978 to 265 million in 2004, but from the mid-1990s onward, the employment situation in most cities started to deteriorate, with the number of jobs not increasing as fast as the labor force, and thus leading to rising unemployment in urban areas ${ }^{3}$. Although the official registered unemployment rate in urban areas stands at 4.2 percent (8.27 million people in 2004), actual unemployment is estimated to be much more severe, especially when unemployment in the form of laid-off workers (xiagang) is considered (Lai 2005). While the exact number of laid-off workers remains largely unknown, estimates provided by the National Bureau of Statistics indicate that there would have been 70 to 80 million workers laid off between 1998 and 2002 from public and non-public enterprises $^{4}$ ( $\mathrm{Li}$ and Bai 2005).

Overall, the basic patterns in urban employment that have emerged are related to enterprise ownership, sector, and regional location. First, urban unemployment mainly

\footnotetext{
${ }^{3}$ Except as otherwise indicated, all macroeconomic data on employment in China are official data from the National Bureau of Statistics (NBS).

${ }^{4}$ The sum of laid-off workers at the beginning of 1998 with newly added laid-off workers during the period from 1998 to 2002 amounts to 27 million (NBS 2003, p. 134). According to Li and Bai (2005), the number of workers laid-off from other types of enterprises would be roughly 50 million. Within state-owned enterprises, the laid-off policy has been implemented largely in small-scale enterprises owned by local governments, which have suffered financial losses (Dong (2003)).
} 
comes from urban state-owned industrial enterprises. While total employment in urban areas has increased over the years, employment in state-owned units has steadily decreased since the mid-1990s, from 112.6 million in 1995 down to 70 million in 2004. The reduction of employment in state-owned and collectively owned units has been partly compensated by the increase of employment in the private sector, the foreign sector, and new enterprises ownership types ${ }^{5}$.

Second, the sharp decrease in employment mainly took place in the most competitive sectors, such as manufacturing, where the number of employed people dropped by 15 percent between 1995 and $2002^{6}$. In contrast, sectors with a state monopoly status such as banking and insurance, and real estate increased their employment by 23 percent and 48 percent respectively over the same period. Third, the regional distribution of urban employment and unemployment is also quite uneven. Northeast provinces, which have been among the hardest hit provinces by the layoff policy, are those that have experienced the sharpest drop in urban employment between 1995 and 2002 (-28 percent). In other regions, the employment level has remained the same, except in the western region where the share of total urban employment increased from 18 to 21 percent.

Over the last decade, there has been a large number of works on the changes in China's wage structure. ${ }^{7}$ This paper analyses labor market segmentation in urban China by focusing on earnings differences within three different dimensions: enterprises' ownership, economic sector, and regional location. We use an original dataset derived from two urban household surveys conducted by the Chinese

\footnotetext{
${ }^{5}$ These include shareholding corporations, limited liability corporations, cooperative units, and others.

${ }^{6}$ Again, these changes are to be related with the laid-off policy, which has been mainly implemented in industries facing strong competition, such as manufacturing and construction. For instance, the number of on-post staff and workers in state-owned enterprises in manufacture fell sharply from 33.3 million in 1995 to 9.8 million in 2002 (NBS 2003, p. 23).

${ }^{7}$ A main area of research analyzes various aspects of labor market segmentation in China, by focusing on earnings gaps between different groups of workers: rural migrants and urban residents (Knight et al. (1999), Meng and Zhang (2001), Maurer-Fazio and Dinh (2004)), men and women either in rural China (Meng and Miller (1995), Meng (1998), Ho et al. (2002), Rozelle et al. (2002), Dong et al. (2004)) or in urban China (Qian (1996), Gustafsson and Li 2000, Liu et al. (2000), Hughes and Maurer-Fazio (2002), Maurer-Fazio and Hughes (2002), Liu et al. (2004), Bishop et al. (2005), Démurger et al. (2007), Ng (2005)) and workers in enterprises of different ownership (Zhao (2001), (2002), Dong and Bowles (2002), Chen et al. (2005)).
} 
Academy of Social Sciences (CASS), which provide detailed information on labor income as well as on individual and household characteristics for urban hukou holders in 1995 and 2002. To assess the extent of labor market segmentation, we first estimate Mincerian earnings equations for each category of enterprises (defined by ownership, sector, or location). We then propose an extended form of Oaxaca-Blinder decomposition methodology to decompose for each dimension the observed earnings differentials into three components: the distribution of individual characteristics, differences in working time, and what can be interpreted as a pure "segment effect". Comparisons of segmentation magnitudes across ownership, sector, and region, and between the two years are expected to provide a broader view on recent changes across the various segments of the Chinese urban labor market.

\section{Major reforms in China's urban labor market}

During the pre-reform period, there was virtually no labor market in China. Job allocation and wage-settings in state-owned enterprises (SOEs) were determined within the central plan and a key function held by SOEs was to provide employment to the entire working-age population. The main features of this centrally determined wage structure were the following ${ }^{8}$. First, the wage determination system was characterized by rigidity with low-level wages and a distribution of wages based on an egalitarian principle. Promotion and wage increases were mostly driven by seniority. Second, SOEs were not only labor providers, but they also provided a number of social welfare benefits, including housing, medical care, pensions, etc., which aimed at compensating for low base wages. Third, with the employment assignment system and the strictly controlled movement of the population within the hukou system, labor mobility across sectors and regions was strongly limited.

Economic reforms launched from the end of the 1970s led to important changes within the state sector (Table 1). In a first step, more autonomy in decision-making for employment and wages has been granted to SOEs managers, who were now

\footnotetext{
${ }^{8}$ A detailed description of the pre-reform wage-setting system is given in Meng (2000, chapter 2). See also Lin et al. (2001) and Knight and Song (2005).
} 
allowed to retain a share of their profit and use it to give bonus wages to their employees. Bonus wages aimed to provide incentives to employees and increase the overall productivity of SOEs. Their amount was also meant to reflect both enterprise and individual performances (Coady and Wang 2000; Meng 2000). However, given high supervision costs, bonuses have often been distributed on an egalitarian basis within work units, and the evaluation of their impact remains controversial.

The industrial reforms also allowed the emergence of a new private sector, composed of domestic private enterprises ${ }^{9}$, individual enterprises (getihu), domestic joint ventures (lianying qiye), foreign-invested enterprises, and share-holding companies (gufenzhi qiye). Although domestic private enterprises suffered from restricting policies such as overtax, strict regulation, limited access to loans and skilled employees in the 1980s, the share of the non-public sector in employment grew steadily from 0 in 1978 to 17 percent in 1995, 45 percent in 2002, and 53 percent in 2004. $^{10}$

Starting from the mid-1990s, other important changes have taken place on the Chinese urban labor market, the most radical being the laid-off policy (xiagang) implemented in state-owned and urban collective enterprises, first in Shanghai only in 1993 and then extended nation-wide in 1997. Given the growing burden of substantial redundant labor in the state sector, the goal of this policy was to lay off a quarter or more of its workers within 4 years (1997-2000) (Appleton et al. 2002). This policy has had a strong impact on employment in the public sector, falling from 112.6 million in 1995 to 71.6 million in 2002 in SOEs and from 31.5 million to 11.2 million in urban collective enterprises.

\footnotetext{
${ }^{9}$ In 1988, the State Council issued the Tentative Stipulations on Private Enterprises (TSPE) to govern the registration and management of private firms. This document defined a private firm as "a for-profit organization that is owned by individuals and employs more than eight people”. Firms that hired eight employees or less can be registered as individual enterprises (getihu). The TSPE identified three types of private firms: those under sole ownership, partnerships, and limited liability companies.

10 The Company Law promulgated in November 1993, provided the legal framework for the development of limited liability companies and shareholding companies.
} 
The second most important change is the wage reform, which was launched in 1994 and grants enterprises more autonomy in setting wages and bonuses. Consequently, the average wage in the state-owned sector has increased substantially, especially in the government sector. Between 1998 and 2002, average earnings in state-owned units have grown by 107 percent in real terms, with an annual growth rate of 10.9 percent. However, the wage reform has also widened the earnings gap between workers and managers, between skilled workers and unskilled workers, and between enterprises making profits and those making losses. During the last two years of Zhu Rongji's administration, salaries in the government sector were raised again by 60 percent, in order to narrow the income gap between civil servants and white-collar workers employed in the non-public sector. ${ }^{11}$

The last major change on the Chinese urban labor market over 1995-2002 is related to rural-urban migration. The policy of city governments for rural migration varies, but the general trend is that employment policies concerning rural migrants was tight up to the end of the 1990s and started to loosen at the beginning of the new century ${ }^{12}$. The participation of rural migrants in the urban labor market has had a great impact on wage levels and unemployment among employees with urban hukou. Rural migrant laborers are very competitive against local urban workers for unskilled jobs, and this puts pressure on the wage level for unskilled workers on the urban labor market, particularly for those whose wage setting is the most strongly related to market mechanisms (Cai 2005; Li and Bai 2005).

\section{A first look at the data}

\section{1 Data}

The data used in this paper come from two nationally representative household income surveys for 1995 and 2002. The surveys are part of the China Household

\footnotetext{
${ }^{11}$ The second objective of this wage adjustment was to stimulate sluggish economic growth. However, while the relative wage in the government sector rose significantly, the macroeconomic effect of the wage adjustment remained quite limited.

${ }^{12}$ In 1998, the Ministry of Public Security issued new regulations relaxing control over hukou registration. In particular, those who join their parents, spouses, and children in cities can now be registered with urban hukou (Cai and Wang (2003)).
} 
Income Project (CHIP) coordinated by the Institute of Economics, Chinese Academy of Social Sciences, with assistance from the National Bureau of Statistics (NBS). ${ }^{13}$ Household samples were drawn from the large sample used by the NBS. ${ }^{14}$ The two urban surveys cover the same provinces and cities, and almost the same number of households. ${ }^{15}$ Although the number of samples in each province is not exactly proportional to its actual population, the two figures are highly correlated, more households being selected from more populated provinces. The 1995 urban data include 6,931 households and 21,694 individuals, and the 2002 urban data 6,835 households and 20,632 individuals. The distribution of households among provinces can be found in Table 2 .

The two urban surveys only cover urban hukou holders and thus exclude a potentially important segment of the urban labor market: the rural-urban migrants. In a changing environment where rural-urban migration is gathering momentum, limiting our study to only urban residents might be misleading. We acknowledge this potential shortcoming in our study, which does not allow for the evaluation of how migration is affecting the urban labor market and wage differentials.

Our sample is restricted to individuals aged 16 to 60 who declared working at least part of the year and earning (positive) wages. Owners of private or individual enterprises are not considered here since wages cannot be disentangled from profit in their case. Laid-off workers are also excluded, which leaves us with a sample of 10,898 employees in 1995 and 9,537 employees in 2002.

The earnings variable is defined as the sum of cash labor compensations and income in kind. Cash labor compensations include the basic salary as well as bonuses,

\footnotetext{
${ }^{13}$ The China Household Income Project is an internationally joint research project established in 1987, and sponsored by the Institute of Economics, the Chinese Academy of Social Sciences, the Asian Development Bank, and the Ford Foundation. Additional support was provided by the East Asian Institute, and Columbia University (Riskin, Zhao, and Li (2000)). Up to now, three household income surveys have been conducted--1988, 1995, and 2002. The output of the project based on the first two surveys can be found in Griffin and Zhao (1993) and Riskin, Zhao and Li (2001).

${ }^{14}$ The sampling method of NBS is briefly explained in NBS 2002, p.318.

${ }^{15}$ The 11 provinces included in the urban survey are Anhui, Beijing, Gansu, Guangdong, Henan, Hubei, Jiangsu, Liaoning, Shanxi, Sichuan, and Yunnan.
} 
allowances (except those given while "waiting for a job”, xiagang) and subsidies (including housing, medical, childcare, and regional subsidies), other wages (including overtime wages and wages for special circumstances), and other income from work unit (except hardship allowances). Hence, our earnings variable includes some non-monetary benefits (e.g. housing, medical care, child care, and regional subsidies), although it does not fully account for all fringe benefits provided by the public sector (such as implicit contribution to pensions, health insurance, or preferential housing rents). Finally, hourly earnings are defined as the ratio between earnings and the number of declared hours worked in a year.

An important component of earnings differentials in China may lie on differences in living standards between different cities. To account at least partially for this factor, earnings are adjusted for provincial purchasing power differences by using Brandt and Holz (2006) urban provincial-level spatial price deflators (the reference being nationwide prices in 2002). In the analysis presented below, earnings are thus expressed in "inter-provincial purchasing power parity", which we believe can be considered as more comparable than non-deflated data usually considered in the literature. Among the consequences of using this purchasing power parity adjustment is that it leads to a reduction in earnings differentials between some regions as compared to the official NBS China Statistical Yearbooks data ${ }^{16}$. It is especially the case for the comparison between municipalities and other regions, since the cost of living in municipalities is much higher.

We focus on the evolution of earnings differentials in various components of the labor market, and consider three different dimensions, namely ownership, economic sector, and geographical location, for each of which, we define several categories.

Five categories of enterprise ownership are considered: state-owned enterprises (SOEs); urban collective enterprises (UCEs); private enterprises (PIEs); foreigninvested enterprises (FIEs); and government agencies or institutions (GAIs). In the

\footnotetext{
${ }^{16}$ See Démurger et al. (2006) for an evaluation of the impact of using deflators on measures of spatial inequality.
} 
course of the 1995-02 period, new categories of enterprises have emerged, notably share-holding corporations (from both the state and others). In our definition of stateowned enterprises, SOEs at the central or provincial level are included as well as local publicly owned enterprises, and for 2002, state share-holding companies. Private enterprises comprise private or individual enterprises, and for 2002, other shareholding companies.

Economic sectors are categorized according to their openness to competition, and are grouped into four categories: competitive sectors, oligopolistic sectors, public services, and government agencies. The competitive sectors are manufacturing, construction, commerce and trade, and food services. The oligopolistic sectors are real estate, public utilities, and finance and insurance. Real estate ${ }^{17}$ is considered as "oligopolistic" for two reasons. First, there are huge structural barriers to entry in this sector, because it requires a large amount of investment. Second, access to land in China is quite closely related to relationship with the government at any level. Both public utilities and finance and insurance are considered oligopolistic sectors because they were not (or hardly) open to the private sector in 2002.

The third economic sector considered here ("public services”) includes health care, sport and social welfare, education, culture and arts, and scientific research. We separate public services from government agencies in the sector dimension because they are different in terms of wage settings. Indeed, while government agencies’ wages are paid only by the government, public services can get additional funding from the market, which may substantially affect wage settings behaviors.

Some economic sectors (mining, geological prospecting and irrigation administration; transportation, storage, post office, and communication; and for social services) could not be clearly classified as defined above. We omitted these sectors from our analysis.

\footnotetext{
${ }^{17}$ There is some inconsistency for the definition of "real estate” between 1995 and 2002. Indeed, in 1995, “real estate” also includes "social services” (such as law companies, housekeepers, reemployment centers, etc.) while in 2002, they are split into two separate categories. We chose not to add-up these two categories for 2002 since social services are mostly competitive. However, we believe that the bias of including social services into real estate in 1995 should not be too large since this sector was still marginal in 1995.
} 
For the third dimension, regional location, we have five regions: coast, center, west, northeast, and metropolises. As the household income surveys do not cover all Chinese provinces, the five regions are represented by a sub-sample of provinces. Beijing is representative of province-level metropolitan cities. Guangdong and Jiangsu are representatives of coastal provinces. Henan, Anhui, Hubei, and Shanxi are representatives of central provinces. Gansu, Sichuan, and Yunnan are representatives of western provinces, and Liaoning is representative of northeastern provinces. ${ }^{18}$

Ideally, we would like to consider the three dimensions highlighted above simultaneously since they are obviously correlated. Among the most prominent correlations, Table 3 shows that 1 ) oligopolistic sectors mostly consist of SOEs and GAIs, 2) private and foreign enterprises are mainly found in the competitive sector as well as in the coastal region, and 3) SOEs are over-represented in the northeast region. However, for practical reasons, it is not possible to consider the three dimensions together. This is because the methodology requires the estimation of earnings equations by sub-categories, and if we were to consider each sub-category (e.g. SOEs in the competitive sector in the coastal region) we would have too few observations. Consequently, in the following analysis, the three dimensions will be analyzed separately, though keeping in mind that they are overlapping.

The main characteristics of employees by dimension and over time are shown in Tables 4, 5, and 6. A first general comment on the evolution between 1995 and 2002 is that both average age and education level have increased over time, while the share of long-term contracts has sharply decreased from 96 percent to below 80 percent.

\footnotetext{
${ }^{18}$ For our purpose, it is more appropriate to consider Liaoning's characteristics as representative of a fifth category of provinces, namely northeastern provinces rather than coastal provinces. Indeed, Liaoning province is quite different from coastal provinces in terms of industrial and ownership structure. Its industrial structure is strongly influenced by strategic choices that have been made during the central planning period, with a predominance of heavy industry sectors, and thus central SOEs. Moreover, it has been one of the most badly hit provinces by the laid-off policy from the end of the 1990s, which has had strong implications in terms of employment structure.
} 
Comparisons by ownership (Table 4) show that government agencies and foreigninvested enterprises employ better-educated workers than other sectors in 1995 and 2002. As compared with private and foreign sectors, workers in the public sector are older and more often party members, with long-term tenure, but they are less likely to be located in coastal provinces. It is noteworthy that the most educated workers are found in public administration, with an average number of years of education (above 12) much higher than in any other type of enterprise for 1995 and 2002. Finally, the regional distribution of the private sector has equalized over time, which may reflect the development of the private sector at the turn of the century all over China, including inland provinces.

As for differences by sectors (Table 5), employees in the competitive sector are less likely to be educated (especially in 2002), party members, and working in SOEs. They are also less likely to have long-term contracts in 2002. Consistent with the ownership dimension, we can observe that it is in public services and in government agencies that the level of education is the highest.

Finally, regional differences (Table 6) show that workers in municipalities tend to have much better characteristics than in other regions in terms of education, experience (higher age), and party membership (for 1995). On the contrary, workers in coastal provinces are less educated and less likely to be party members (with a lower share of SOEs), which may be consistent with the non-skilled labor-intensive outward-oriented light industrial structure of these provinces. For the Northeast region, the downsizing of the state-owned sector has been particularly large between 1995 and 2002; the share of SOEs employment of 63 percent in 2002 is the lowest across regions. The share of employees with long-term contracts has also dropped most radically in the northeast, from the highest in 1995 (nearly 98 percent) to the lowest in 2002 (64 percent). 


\section{2 The evolution of earnings differentials by categories}

Descriptive statistics on earnings differentials and earnings composition across the three dimensions are given in Tables 7, 8, and $9^{19}$. In terms of ownership (Table 7), workers at government agencies and institutions have gained a lot, with a doubling in earnings. This huge increase resulted in a changing sign of the observed earnings differential with foreign-invested enterprises in 2002. Hence, while foreign-invested enterprises were providing the highest total earnings in 1995, the huge earnings increase in government agencies and institutions moved them up to the first rank with wages similar to foreign-invested enterprises in $2002^{20}$. On the other hand, urban collective enterprises as well as private and individual enterprises have seen their relative position deteriorating, the largest gap with other enterprises jumping from 67 to 78 percent and 57 to 64 percent respectively between 1995 and 2002.

In terms of economic sectors (Table 8), the difference between the competitive and the non-competitive sectors (oligopolistic, public services, and government) has turned larger over time, with the earnings gap in favor of non-competitive sectors increasing from a range of 10 - 17 percent to 48 - 63 percent. A somehow similar change, with much lower amplitude though, has also taken place across noncompetitive sectors, with the largest gap between two non-competitive sectors increasing from 6 percent in 1995 to 10 percent in 2002.

Furthermore, coefficients of variation (c.v.) on total earnings indicate a more equitable distribution of earnings in the public sector (SOEs and GAIs) as compared to the private/competitive sectors for both years. The earnings composition has also changed over time, the most notable change being the sharp reduction in the share of subsidies provided by SOEs (which comes from a 50 percent reduction of the absolute amount in SOEs). Consequently, while the public sector was offering much higher

\footnotetext{
${ }^{19}$ All the data discussed in the remaining of this paper are deflated, using Brandt and Holz (2006) urban provincial-level spatial price deflators as explained above.

${ }^{20}$ The observed difference in 2002 is not statistically significant.
} 
subsidies than the private sector in 1995, it is no longer the case in 2002, except in public administration $^{21}$.

At the beginning of economic reform, the earnings difference between coastal provinces and inner provinces was extremely small. ${ }^{22}$ Then, as indicated in Knight et al. (2001), a significant divergence in earnings growth across provinces in urban areas arose between 1988 and 1995. Our data (Table 9) indicate that no further divergence across the different geographical regions can be observed between 1995 and 2002 when earnings are adjusted by regional living costs. The relative differences between coastal provinces and central and western provinces were slightly reduced over the period, but the premium offered by the former still stands at 37 percent compared with central provinces and 28 percent compared with western provinces. The comparison between municipalities and other regions shows that taking account of differences in living costs sharply lowers the premium in favor of municipalities, especially compared with coastal provinces.

Lastly, the comparison of the number of hours worked per week shows a longer working time in the private sector than in the public sector for the two years, despite a reduction in the number of hours worked in both private or individual enterprises and foreign-invested enterprises in 2002. The comparison across economic sectors confirms that workers in public services and in government agencies work less, but it also shows that working time in the competitive sector has increased over time while it has decreased in the oligopolistic sector, leading to a quite important gap between competitive and non-competitive sectors in 2002 (about 4 hours per week). Regional comparisons do not reveal strong differences in working time across regions, except for a sizeable reduction in hours worked in municipalities between 1995 and 2002, which is not observed in other regions.

\footnotetext{
${ }^{21}$ In 1995, there were still some institutional limitations on wage settings. This can be seen clearly from basic wages, which were quite similar across different sectors with the main determinants of earnings differences being income outside basic wage.

${ }^{22}$ In fact, average earnings in the western region were even higher than that in the coastal region. For instance, in 1978, it was 696 yuan in the eight western provinces (Sichuan, Guizhou, Yunnan, Shaanxi, Gansu, Qinghai, Ningxia, and Xinjiang) and 666 yuan in the eight coastal provinces (Tianjin, Liaoning, Shanghai, Jiangsu, Zhejiang, Fujian, Shandong, and Guangdong) (NBS 1999, p.139).
} 


\section{Methodology}

In order to analyze earnings differentials between individuals belonging to different segments in the labor market (across ownership, sector, or region), we use an extended version of Oaxaca-Blinder decompositions (Blinder 1973; Oaxaca 1973) to evaluate the contribution of three complementary factors: differences in mean endowments of workers across segments, differences in hours worked, and a pure “segment effect”.

\section{1 Modeling total earnings}

Let $w_{s}^{i}$ represent hourly earnings for individual $i$ belonging to segment $s . w_{s}^{i}$ depends on two sets of arguments: individual characteristics $\left(x_{s}^{i}\right)$, and a set of segment specific parameters corresponding to the earnings model linking individual characteristics with observed earnings $\left(\beta_{s}\right)$.

$$
w_{s}^{i}=W\left(x_{s}^{i} ; \beta_{s}\right)
$$

Symmetrically, let $h_{s}^{i}$ represent the number of hours worked by individual $i$ belonging to segment $s . h_{s}^{i}$ also depends on two sets of arguments: individual and household characteristics determining labor supply $\left(z_{s}^{i}\right)$, and a set of segment specific parameters $\left(\gamma_{s}\right)$.

$$
h_{s}^{i}=H\left(z_{s}^{i} ; \gamma_{s}\right)
$$

The total individual income $(I)$ derived from segment $s$ can be expressed as:

$$
\begin{aligned}
I_{s}^{i} & =w_{s}^{i} \cdot h_{s}^{i} \\
& =W\left(x_{s}^{i} ; \beta_{s}\right) . H\left(z_{s}^{i} ; \gamma_{s}\right)
\end{aligned}
$$




\section{2 Decomposition of observed earnings differentials}

Using equation (3), the observed average earnings gap between two segments $s$ and $S$ can be decomposed as follows:

$$
\begin{aligned}
\overline{I_{S}^{i}}-\overline{I_{s}^{i}}= & \bar{W}\left(x_{S}^{i} ; \beta_{S}\right) \cdot \bar{H}\left(z_{S}^{i} ; \gamma_{s}\right)-\bar{W}\left(x_{s}^{i} ; \beta_{s}\right) \cdot \bar{H}\left(z_{s}^{i} ; \gamma_{s}\right) \\
= & \bar{W}\left(x_{S}^{i} ; \beta_{S}\right) \cdot \bar{H}\left(z_{S}^{i} ; \gamma_{S}\right)-\bar{W}\left(x_{s}^{i} ; \beta_{S}\right) \cdot \bar{H}\left(z_{s}^{i} ; \gamma_{s}\right) \quad: \text { Difference in endowments } \\
& +\bar{W}\left(x_{s}^{i} ; \beta_{S}\right) \cdot \bar{H}\left(z_{s}^{i} ; \gamma_{S}\right)-\bar{W}\left(x_{s}^{i} ; \beta_{S}\right) \cdot \bar{H}\left(z_{s}^{i} ; \gamma_{s}\right) \quad: \text { Difference in hours worked } \\
& \overline{+W}\left(x_{s}^{i} ; \beta_{S}\right) \cdot \bar{H}\left(z_{s}^{i} ; \gamma_{s}\right)-\bar{W}\left(x_{s}^{i} ; \beta_{s}\right) \cdot \bar{H}\left(z_{s}^{i} ; \gamma_{s}\right) \quad: \text { Segment effect" }
\end{aligned}
$$

This decomposition provides an evaluation of what would be the observed average earnings gap under the following conditions:

i) If workers observed in different categories were facing the same conditions in the determination of remuneration and of hours worked, the wage difference reflects pure difference-in-endowments effect.

ii) If workers observed in different categories were facing the same conditions in the determination of remuneration and were endowed with the same characteristics, the wage difference reflects pure difference-in-hours worked effect.

iii) If workers observed in different categories were facing the same conditions in the determination of hours worked and were endowed with the same characteristics, the wage difference reflects pure “segment effect”.

\section{3 Implementation and robustness issues}

The practical implementation of the method consists of three steps. First, earnings equations and hours worked equations are estimated separately for each segment (see Appendix). Second, estimated coefficients are used to predict hourly earnings and hours worked for each individual and each segment. Third, each of the effects presented in equation (4) is evaluated by averaging over individuals the corresponding observed or counter-factual earnings values.

4. 3. 1 Earnings equations Decomposition results presented below correspond to the specification for earnings equation estimations detailed in Appendix A and B. The common explanatory variables for hourly earnings functions are effective number of years of education; a dummy variable if the individual has received vocational 
education; effective years of work experience and the square of this variable; a dummy variable for "big cities"; and a dummy variable for acquisition of the current urban residence permit (hukou). Regional dummies are used as additional explanatory variables in the ownership and sector dimensions.

Selectivity bias in enterprise type and industrial sector choices may affect the estimated coefficients from earnings equations and thus decomposition results. In the absence of any credible exogenous instrument in the data, we proceeded without corrections for selection bias. In any case, our decomposition findings are robust to changes in both specification and estimation methods. ${ }^{23}$ However, it should be stressed that, although labor has been administratively allocated in China up to 1995 and labor mobility remained quite low until this date, selection may definitely be a more important issue in 2002. While the development of labor market has allowed mobility to increase, SOE-restructuring has led to a selective laying-off of workers. Our dynamic interpretations in terms of segmentation changes might thus be partly driven by selection mechanisms.

\section{3. 2 Decomposition: path-dependence A general issue concerning Oaxaca-}

Blinder decompositions concerns path-dependence (Fournier 2005). Indeed, evaluated effects a priori depend on the benchmark population structure or coefficient vector chosen to run micro-simulations. In our work, each possible evaluation is considered and used as a robustness test for our decomposition results ${ }^{24}$. Moreover, since decomposition results obtained from this type of analyses strongly depend on estimation quality, a bootstrap procedure has been implemented over the whole procedure (estimation, simulation, and decomposition). ${ }^{25}$ The following decomposition tables include the corresponding 95 percent confidence intervals.

\footnotetext{
${ }^{23}$ In particular, results obtained through the two-step method proposed by Dubin and McFadden (1984), with sector choice and enterprise choice modeled as multinomial Logit and local shares of employment in various sectors used as instruments, led to similar results for all aspects considered in this paper.

${ }^{24}$ Each effect can be evaluated in six different ways, depending on the choice of reference populations and coefficient vectors as well as on the choice of the sequence in which different effects are evaluated. ${ }^{25}$ By resampling from the original data, the nonparametric boostrap method allows for the derivation of confidence intervals for all statistics obtained through the microsimulation procedure presented above.
} 


\section{Decomposing the evolution of earnings differentials by categories}

Tables 10, 11, and 12 document the changes in relative remunerations across enterprises of different ownership/sector/region in urban China, by applying the extended Oaxaca-Blinder decomposition method presented above. Differentials are reported both in mean value and in percentage of the lowest earnings, the stars indicating the statistical significance of estimated effects. For example, the "Endowment effect” figures reported on the first row of Table 10 read as follows. Of the 1,299 yuan observed average earnings gap between SOEs and UCEs in 1995, 352 yuan can be attributed to better characteristics observed in SOEs, which would lead, other things equal, to a 7 percent average earnings gap against UCEs (instead of the 27 percent observed differential). ${ }^{26}$

\section{1 Ownership structure}

In the first column of Table 10, observed earnings differences across enterprises of various ownership show a general increasing trend between 1995 and 2002, the only (noteworthy) exception being between FIEs and GAIs ${ }^{27}$. The evolution has been in favor of both FIEs and GAIs, and at the expense of UCEs. In the middle, employees in SOEs have seen their earnings gap increased compared to UCEs, but their situation has deteriorated compared to GAIs. The most striking result from Table 10 is the growing importance (and significance) of segmentation as the most prominent explanatory factor for the general increasing trend in earnings differences across ownership.

Earnings differentials in favor of the foreign sector in 1995 have increased over time compared to the emerging domestic private sector, but decreased compared to the public sector. The deteriorating position of FIEs as compared to GAIs mainly comes from changing segmentation patterns (from 14 percent in favor of FIEs to a nonsignificant 5 percent in favor of GAIs), although a higher working time in FIEs gives

\footnotetext{
${ }^{26}$ Both figures are statistically significant at the 5 percent level as shown by corresponding confidence intervals provided under the " $5 \%$ " and " $95 \%$ " headings.

${ }^{27}$ The FIE-GAI gap vanished from 22 percent in favor of FIEs in 1995 to a low and non-significant 2 percent in favor of GAIs.
} 
them a premium over GAIs (5 percent). Compared to SOEs, the observed decrease in earnings differential mainly comes from decreasing segmentation in favor of FIEs (from 23 percent to 16 percent). A stronger segmentation in favor of FIEs can be found when compared to UCEs and PIEs. The earnings gap between FIEs and UCEs (67 - 74 percent) comes from the conjunction of a strong and increasing segmentation (40 - 51 percent), better characteristics (17 - 20 percent) and a longer (although reducing) working time in FIEs. For the comparison with PIEs, figures for 1995 must be taken with caution since estimations do not perform very well for this year, and the number of observations in this particular category are small (see Appendices A1 and B1). However, it is instructive to examine earnings differentials in 2002. The comparison with FIEs shows a strong segmentation: the premium in favor of FIEs would be 65 percent in 2002 if there were no differences in characteristics and hours worked with PIEs. However, longer working time in PIEs reduces the gap by 11 percentage points on average.

In 1995, the earnings differential between the public sector and urban collectives was all in favor of the former (27 percent for SOEs and 37 percent for GAIs), and was explained by the conjunction of both better endowments of workers in the public sector and a rather strong segmentation against urban collectives (respectively 17 and 27 percent). Interestingly, the huge increase in the earnings gap between GAIs and UCEs over time (reaching 78 percent in 2002) can be attributed to a much stronger segmentation (65 percent) but also, and rather importantly, to a widening gap in terms of workers endowments, with an increase of the wage premium due to better characteristics from 9 percent to 18 percent. On the opposite, changes in hours worked are reducing the gap in 2002 between UCEs and both SOEs and GAIs, but with quite a small impact (respectively 3 percent and 6 percent).

In 2002, the comparison between PIEs and the public sector also shows high earnings differentials against PIEs, the premium in favor of the public sector ranging from 31 percent to 64 percent. Again, these gaps are driven by a strong segmentation phenomenon (50 - 78 percent), which cannot be compensated by longer hours worked 
in the private sector though this last effect is quite high and significant (18 - 21 percent).

The decomposition analysis presented here highlights three main phenomena on the ownership dimension, which are of importance to understand the evolution of the labor market in urban China. First, workers in the public sector, especially government agencies and institutions, are still very much privileged as compared to other segments of the labor market. Second, the foreign sector has reinforced its position through a sustained high wage policy. Third, the emerging domestic private sector and the collective sector have seen their relative position deteriorating. These results show that despite the increasing importance of market mechanisms within the private sector, active policies launched at the end of the 1990s to raise government wages have had a strong impact in terms of segmentation, which confirms that earnings in the public sector remain highly protected. It should be stressed that there might also be a sizeable selection effect at stake here since the downsizing of the state sector has led to the privatization of the least dynamic enterprises, the Chinese authorities still controlling large profit-making SOEs where employees remain strongly protected.

\section{2 Economic sectors}

The decomposition results by economic sectors presented in Table 11 also highlight quite a strong and rising segmentation between competitive and protected sectors. In 1995, segmentation against the competitive sectors contributed to more than half of the total average earnings differences. In 2002, the main reason why the competitive sectors provided much lower wages than the rest of the sectors (between 48 percent and 63 percent) almost exclusively comes from the segmentation effect, which is strongly reinforced as compared to 1995, and ranges from 50 percent to 64 percent.

By the end of the 1990s, SOEs began to retreat from the competitive sector, while strengthening their position in non-competitive sectors, especially in the oligoplistic sector. SOEs downsizing and massive lay-offs are the main reasons for the surge in unemployment at the end of the 1990s, but our decompositions indicate no change in 
terms of the relative wage level for the remaining employees in the oligopolistic sector. The comparison between the competitive sector and the oligopolistic sector even reveals no significant differences in workers' characteristics, the only determinant explaining the large difference being the segmentation effect.

These findings can be analyzed in terms of profit sharing within oligopolistic sectors (Li and Bai 2005; Knight and Li 2005). Moreover, institutional explanations lie in the increased autonomy in wage settings and increased wages for civil servants provided by the Chinese government over the period. This has allowed the oligopolistic sector and public services to redistribute rents to employees, while the competitive sector has been facing growing competition.

Not only the wage level, but also working hours have changed under the pressure of competition. During the period, working time has increased in the competitive sectors while at the same time, the non-competitive sectors somewhat reduced their working hours. Given this differentiated evolution, changes in hours worked are partly hiding the magnitude of the evolution. Indeed, if workers in the competitive sectors were not working longer, the observed differences of 48 percent to 63 percent would be even larger by 8 to 10 percentage points. Hence, if there were no segmentation and only differences in the hours worked, the earnings level for similar workers in competitive sectors would be higher than the oligopolistic sectors, and quite close to public services and government jobs.

Within the non-competitive sector, observed earnings differences also turned larger in 2002. For both years, endowments in the oligopolistic sector are slightly lower than in the other two sectors. This is especially the case for the comparison with public services, in which endowments (9 - 5 percent) are significantly higher than in the oligopolistic sector and drive a major part of the observed earnings gap (6 - 10 percent). Antithetically, public services show small endowment differences with the government sector in 1995, but benefit from a favorable segmentation effect (6 percent), which turned even larger in 2002 (13 percent). This somewhat surprising segmentation phenomenon may be explained by the fact that in public services, wages 
are derived partly from the government, and partly from the market. The marketization of this sector has allowed workers in public services to get rising extra wage income (bonus, subsidy, etc.) on top of wages provided by the government.

The sector decomposition confirms and completes some of the findings from the ownership analysis, with a rising segmentation over 1995-02 in favor of the noncompetitive sectors. Three facts can be highlighted here to explain observed earnings differences and evolutions over the period studied: 1) increasing competition within the competitive sector; 2) increasing concentration of large SOEs within oligopolistic sectors; and 3) increasing protection of government jobs.

\section{3 Regional segmentation}

Consistent with the findings in the other two dimensions, regional decompositions show a trend of rising segmentation (Table 12). Regional disparities, especially between coastal provinces and other regions remain large, the highest gap still being close to 40 percent in 2002. A sizeable part of the observed earnings gap between regions can be attributed to a more rapid economic growth and huge capital inflow in the coastal region, and to inadequate labor mobility between regions. As illustrated in many studies (e.g. Knight and Yueh 2006), labor mobility is still limited for urban local workers subject to various institutional obstacles even at the end of 1990s, while regional mobility among rural migrant workers increased over time.

Table 12 shows that the share of regional differences resulting from segmentation, particularly between coastal region and other regions, is remarkably large in the two years and became stronger in almost each pair of regions. Segmentation explains the major part of the observed earnings difference between the coastal and central region (35 - 41 percent), between the coastal and western region (28 percent), and between the coastal and northeast region (40 - 41 percent).

A remarkable change between 1995 and 2002 is the deteriorating relative position of central provinces. This change may be rooted in the fact that the region has been disregarded in the strategy of regional development of the central government. 
However, despite declining relative earnings and increasing segmentation against workers in the region, central provinces have improved their relative position in terms of endowment in 2002. All endowment effects against central provinces in 1995 (ranging from 2 to 15 percent) reversed or became no longer significant in 2002. This may be because skilled and well-educated laid-off workers from closed SOEs had to take jobs that were previously filled by unskilled and poorly educated workers. The better-endowed people remained active while low-endowed people were forced to exit the labor market.

On the opposite, the position of the western region in terms of segmentation has improved somewhat between 1995 and 2002. One possible interpretation is that the Western Development Strategy has raised the relative level of earnings in western provinces, allowing then to maintain their relative position with respect to coastal provinces ( around 30 percent earnings gap) in a context of growing regional segmentation.

The northeastern provinces, represented by Liaoning, deserve special attention. The relative earnings in the northeast region slightly decreased compared to other regions except municipalities between 1995 and 2002, which is reflected in rising observed earnings gaps between the northeast region and other regions. Concerning segmentation phenomena, the evidence is mixed: stable segmentation in favor of coastal provinces (40 - 41 percent), western provinces (10 - 11 percent), and municipalities (17 - 20 percent) on one hand, and decreasing segmentation in favor of central provinces (7 percent in 1995 to non-significant in 2002) on the other hand. This pattern can be at least partly explained by a declining endowment effect against the northeast region due to selection mechanisms. With the massive lay-offs and closures of some large scale enterprises, the absence of local re-employment opportunities caused better educated employees (e.g. professionals, technician and skilled workers) to move to other provinces.

Regional decompositions provide further evidence of rising segmentation on China's urban labor market and complement the other two dimensions by highlighting quite 
large regional disparities and the unequal distribution of gains or burdens related to changes in the labor market at the turn of the century. They also stress the importance of the Chinese government's regional policies in alleviating burdens in some regions (e.g. western provinces) and redistributing the benefits of economic development. In this context, central provinces appear to be by far the greatest (relative) looser in the recent reform process, facing increasing segmentation, even as compared to western and northeastern provinces.

\section{Conclusion}

This paper analyzes the evolution of labor market segmentation for urban hukou holders between 1995 and 2002. During the 7-year period, real earnings in urban China have increased sharply (+78 percent) and for all workers, with substantial differences across ownership and sectors, and to a lesser extent, regions. As a result, earnings differentials across enterprises have changed dramatically and sometimes induced a re-ranking.

Our decomposition results show strong evidence of a multi-tiered labor market along three major lines, segmentation arising across enterprise ownership (up to 78 percent), economic sectors (up to 64 percent), and regions (up to 41 percent). They also highlight increasing segmentation over time within each of these three dimensions. In particular, the gap between the privileged segments of the labor market (e.g. SOEs and oligopolitistic sectors) and the most competitive segments (e.g. private enterprises and competitive sectors) has widened between 1995 and 2002. Our results confirm the Knight and Song (2003) findings that "the market forces operating in the growing private sector and the relative immunity of the state sector from those forces generated greater wage segmentation among types of ownership [between 1995 and 1999], and provincial differences in the place of reform and in economic growth created spatial segmentation in wages that could not be removed by the equilibrating movement of labor” (Knight and Song 2003, 616). 
In the view of the massive layoffs in the state-owned sector at the end of the 1990s and the concomitant impressive growth of the private sector, one might have expected segmentation not to increase so sharply given the growing importance of market mechanisms and competition in the urban labor market. However, the clear distinction found between a "protected" well-paying segment and a "competitive” segment mostly made of the emerging private sector stresses a strongly segmented labor market in 2002. More specifically, our findings suggest that there are two directions toward which the urban labor market in China is moving. On one hand, economic liberalization has brought various benefits to the labor system, including better signals for a more efficient allocation of labor and improved incentives for efforts thanks to enhanced rewards to effort. On the other hand, various institutional as well as marketbased elements have prevented equalization of marginal products, and thus reduction in earning differences. Major explanations for the strong and rising magnitude of segmentation between 1995-02 can be found in migration restrictions and in active government policies towards the public sector, but certainly in efficiency-wage related behavior in the foreign sector.

The observed increasing spatial segmentation reflects the still extremely low mobility of labor among urban dwellers, which represents a major obstacle to the formation of competitive market wages in urban areas. Even though regional mobility for ruralurban migrant workers has increased over time and the effectiveness of institutional barriers such as the hukou system has progressively declined, various institutional obstacles remained to labor mobility for urban residents even at the end of the 1990s. As a result, market mechanisms favoring wages convergence could not operate properly. The evidence found here supports Knight and Song (2005) findings of a “three tier” labor market in 1999, which consists of "privileged” urban residents never made redundant during the SOEs downsizing process, retrenched urban workers, and rural-urban migrants. The upper segment is employees in the public sector and/or the oligopolistic sectors, while the second segment is consistent with a more competitive private sector characterized by short-term contracts and by downward pressures on wages coming from the third segment (the rural-urban migrants). It must be remembered that our empirical analysis is only based on data collected for urban 
hukou holders, i.e. local urban residents. Consequently, it does not encompass the whole labor market in cities where huge inflows of rural-urban migrants are potentially key components of the urban labor market.

Contrary to European economies in transition, where studies found a wage premium in favor of the private sector after economic liberalization (Adamchick and Bedi 2000; Lokshin and Jovanovic 2003), our results highlight earnings differences in favor of the public sector in China after controlling for workers' characteristics and working time. Hence, even during the most recent period, the Chinese government has kept its influence on the urban labor market through wage income increases for civil servants and by maintaining the relative income of workers in SOEs, as well as by targeting specific provinces. Compared to European economies in transition, the Chinese government has taken active policies through wage adjustments to narrow the income gap between civil servants and white-collar workers employed in the nonpublic sector and thus keep skilled workers in the public sector. In this respect, the observed segmentation structure helps the public sector to retain skilled workers. It also reduces incentives for moonlighting and thus compromises the overall efficiency of the public sector, which have been observed in Poland or Yugoslavia (Adamchick and Bedi 2000; Lokshin and Jovanovic 2003).

The existence of segmentation in the labor market may also be interpreted in terms of efficiency wage theory, especially for the comparison between FIEs and domestic (public and private) enterprises, and to some extent between coastal provinces and other regions. In this line of thought, higher earnings received in FIEs may be interpreted as means to facilitate workers' cooperation, to boost their effort-intensity, and more generally, to improve the average quality of job applicants. Since FIEs in China face greater difficulties in employee supervision due to language barriers and cultural differences, they may be willing to pay wages above market rates to solve part of these difficulties and to protect their investment in employees' screening, hiring, and training. Following this approach, economic liberalization and growing market participation may be consistent with the payment of wages exceeding a pure competitive level. 
If these two last points may provide some economic rationale to high and even rising segmentation, increasing segmentation associated to a non-uniform move of enterprises toward the payment of competitive market wages may yield further sources of income inequality. Indeed, evidence shows that during the 7-year period, the structure of wages has become more unequal. ${ }^{28}$ As highlighted by Khan and Riskin (2005), the concentration ratio for urban wages increased by 68 percent between 1995 and 2002. Our results confirm this trend and the potential perverted effects of a multi-tiered urban labor market on income inequality.

Finally, there are good reasons to believe that the observed increasing segmentation may be only a temporary phenomenon. Indeed, given the process of SOEs downsizing, ownership structure may lose importance in the end. At the same time, the growing importance of the private sector might be expected to put more pressure on the urban labor market in the future by bringing in stronger competition and challenging the privileged situation of employees in the public and oligopolistic sectors. Similarly, population movements across provinces and regions are also on the rise and may re-balance regional disparities in the end.

\section{References}

Adamchick, Vera A., and Arjun S. Bedi. 2000. Wage differentials between the public and the private sectors: Evidence from an economy in transition. Labour Economics 7(2): 203-24.

Appleton, Simon, John Knight, Lina Song, and Qingjie Xia. 2002. Labor retrenchment in China: Determinants and consequences. China Economic Review 13(2-3):252-275.

Bishop, John A., Feijun Luo and Fang Wang. 2005. Economic transition, gender bias, and the distribution of earnings in China, Economics of Transition 13(2):239-259.

\footnotetext{
${ }^{28}$ However, Khan and Riskin (2005) and Démurger et al. (2006) have shown that urban household disposable income inequality has been slightly but significantly decreasing over the period.
} 
Blinder, Alan S. 1973. Wage Discrimination: Reduced Form and Structural Estimates. Journal of Human Resources 8(4): 436-55.

Boeri, Tito and Katherine Terell. 2002. Institutional Determinants of Labor Reallocation in Transition. Journal of Economic Perspectives 16(1): 51-76.

Brandt, Loren, and Carsten A. Holz. 2006. Spatial Price Differences in China: Estimates and Implications. Forthcoming in Economic Development and Cultural Change 55(1).

Cai, Fang. 2005. Reform of Labor Policy in China: A Perspective of Political Economy. In CHINA: An Economics Research Study Series - Volume 4: Reforming China, edited by the Institute of World Economics and Politics, Chinese Academy of Social Sciences. Singapore: Marshall Cavendish Academic.

Cai, Fang and Wang Dewen. 2003. Migration as marketization: What can we learn from China's 2000 census data? The China Review 3(2):73-93.

Chen, Yi, Sylvie Démurger, and Martin Fournier. 2005. Earnings differentials and ownership structure in Chinese enterprises. Economic Development and Cultural Change 53(4):933-958.

Cheng, Tiejun and Mark Selden. 1994. The Origins and Social Consequences of China’s Hukou System. The China Quarterly 139:644-668.

Coady, David P., and Limin Wang. 2000. Equity, efficiency, and labor-market reforms in urban China: the impact of bonus wages on the distribution of earnings. China Economic Review 11(3):213-231.

Démurger, Sylvie, Martin Fournier and Yi Chen. 2007. The Evolution of Gender Earnings Gaps and Discrimination in Urban China: 1988-1995. Forthcoming in The Developing Economies 45(1).

Démurger, Sylvie, Martin Fournier and Shi Li. 2006. Urban income inequality in China revisited (1988-2002). Forthcoming in Economics Letters.

Dong, Xiao-yuan. 2003. China's urban labor market adjustment: a summary of literature review. Available at http://info.worldbank.org/etools/docs/library/74068/ china/readings/oct28/dong28engl.pdf.

Dong, Xiao-yuan, and Paul Bowles. 2002. Segmentation and discrimination in China's emerging industrial labor market. China Economic Review 13(2-3):170-196.

Dong, Xiao-yuan, Fiona MacPhail, Paul Bowles, and Samuel P. S. Ho. 2004. Gender Segmentation at Work in China's Privatized Rural Industry: Some Evidence from Shandong and Jiangsu. World Development 32(6): 979-998. 
Dubin, Jeffrey A., and Daniel L. McFadden. 1984. An econometric analysis of residential electric appliance holdings and consumption. Econometrica 52(2): 345362.

Falaris, Evangelos M. 2004. Private and public sector wages in Bulgaria. Journal of Comparative Economics 32(1): 56-72.

Fleisher Belton. M., and Dennis. T. Yang. 2003. Labor laws and regulations in China. China Economic Review 14(4): 426-433.

Fournier, Martin. 2005. Exploiting Information from Path Dependency in OaxacaBlinder Decomposition Procedures. Applied Economics Letters 12(11): 669-672.

Giles, John, Albert Park, and Fang Cai. 2006. How has Economic Restructuring Affected China's Urban Workers? The China Quarterly 185: 61-95.

Griffin, Keith, and Zhao Renwei. 1993. The Distribution of Income in China. London: Macmillan.

Gustafsson, Björn, and Li Shi. 2000. Economic transformation and the gender earnings gap in urban China. Journal of Population Economics 13(2):305-329.

Hausman, Jerry. 1978. Specification Tests in Econometrics. Econometrica 46: 12511271.

Hughes, James, and Margaret Maurer-Fazio, 2002. Effects of Marriage, Education and Occupation on the Female/Male Wage Gap in China. Pacific Economic Review 7(1):137-156.

Ho, Samuel P. S., Xiaoyuan Dong, Paul Bowles and Fiona MacPhail, 2002. Privatization and enterprise wage structures during transition: Evidence from rural industry in China. Economics of Transition 10(3): 659-688.

Khan, Azizur R., and Carl Riskin, 2005. China’s household income and its distribution, 1995 and 2002. The China Quarterly 182: 356-384.

Knight, John, and Li Shi. 2005. Wages, Firm Profitability and Labor Market Segmentation in Urban China. China Economic Review 16(3): 205-228.

Knight, John, Li Shi and Zhao Renwei. 2001. A Spatial Analysis of Wages and Incomes in Urban China: Divergent Means, Convergent Inequality. In China's Retreat from Equality: Income Distribution and Economic Transition, edited by Carl Riskin, Zhao Renwei and Li Shi. New York: M.E. Sharpe.

Knight, John, and Lina Song. 1995. Towards a labor market in China. Oxford Review of Economic Policy 11(4):97-117. 
- 2003. Increasing urban wage inequality in China: Extent, elements and evaluation. Economics of Transition 11(4):597-619.

—. 2005. Towards a Labour Market in China. Oxford: Oxford University Press.

Knight, John, Lina Song, H. Jia. 1999. Chinese Rural Migrants in Urban Enterprises: Three Perspectives. In The Workers' State Meets the Market: Labor in China's Transition, edited by Sarah Cook and Margaret Maurer-Fazio. London: Frank Cass.

Knight, John and Linda Yueh. 2006. Job Mobility of Residents and Migrants in Urban China. In Unemployment, Inequality and Poverty in Urban China, edited by Li Shi and Hiroshi Sato. London: RoutledgeCurzon.

Lai, Pingyao. 2005. China’s Economic Growth: New Trends and Implications. In CHINA: An Economics Research Study Series - Volume 4: Reforming China, edited by the Institute of World Economics and Politics, Chinese Academy of Social Sciences. Singapore: Marshall Cavendish Academic.

Li, Shi and Bai Nansheng. 2005. China Human Development Report - Development with Equity. Beijing: UNDP and China Development Research Foundation.

Lin, Justin Y., Fang Cai, and Zhou Li. 2001. State-owned enterprise reform in China. Hong Kong: Chinese University Press.

Liu, Pak-Wai, Xin Meng, and Junsen Zhang. 2000. Sectoral gender wage differentials and discrimination in the transitional Chinese economy. Journal of Population Economics 13(2):331-352.

Liu, Pak-Wai, Junsen Zhang, and Shu-Chuen Chong. 2004. Occupational segregation and wage differentials between natives and immigrants: evidence from Hong Kong. Journal of Development Economics 73:395-413.

Liu, Pak-Wai, Junsen Zhang, and Ching Yi Kung. 2004. What Has Happened to the Gender Wage Differential in Urban China During 1988-1999? Available at http://econrsss.anu.edu.au/pdf/china-abstract-pdf/Zhang-Kung.pdf

Lokshin Michael M., and Branko Jovanovic. 2003. Wage differentials and state private sector employment choice in Yugoslavia. Economics of Transition 11(3):463491

Maurer-Fazio, Margaret, and Ngan Dinh. 2004. Differential rewards to, and contributions of, education in urban China's segmented labor markets. Pacific Economic Review 9(3):173-189.

Maurer-Fazio, Margaret, and James Hughes. 2002. The Effects of Market Liberalization on the Relative Earnings of Chinese Women. Journal of Comparative Economics 30(4):709-731. 
Meng, Xin. 1998. Male-female wage determination and gender wage discrimination in China's rural industrial sector. Labour Economics 5(1): 67-89.

Meng, Xin. 2000. Labour market reform in China. Cambridge, UK: Cambridge University Press.

Meng, Xin, and Paul Miller. 1995. Occupational Segregation and its Impact on Gender Wages Discrimination in China's Rural Industrial Sector. Oxford Economic Papers 47(1):136-155.

Meng, Xin, and Junsen Zhang. 2001. The Two-Tier Labor Market in Urban China Occupational Segregation and Wage Differentials between Urban Residents and Rural Migrants in Shanghai. Journal of Comparative Economics 29:485-504.

Ministry of Labor and Social Security (MOLSS) and Literature Research Office of CCCPC (2002). Selected Important Documents of Labor and Social Security in the New Period. Beijing: Publishing House of MOLSS.

Mincer, Jacob. 1974. Schooling, experience, and earnings. New York: National Bureau of Economic Research.

National Bureau of Statistics (NBS). 1999. Comprehensive Statistical Data and Materials on 50 Years of New China. Beijing: China Statistics Press.

National Bureau of Statistics (NBS). 2002, 2003. China Statistical Yearbook. Beijing: China Statistics Press.

National Bureau of Statistics (NBS) and Ministry of Labor and Social Security (MLSS). 2003. China Labor Statistical Yearbook. Beijing: China Statistics Press

Ng, Ying Chu. 2005. Gender Earnings Differentials and Regional Economic Development in urban China, 1988-1997. Available at http://www.wider.unu.edu/research/2004-2005/2004-2005-6/agenda/31_Ying\%20Chu\%20Ng_Gender\%20Earnings_English.pdf

Oaxaca, Ronald L. 1973. Male-Female Wage Differentials in Urban Labor Markets. International Economic Review 14(3):693-709.

Qian, Jieyong. 1996. Gender Wage Differentials in Urban China in the 1990s. PhD. Dissertation. Binghamton: State University of New York.

Riskin, Carl, Renwei Zhao, and Shi Li. 2000. Chinese Household Income Project, 1995 [Computer file]. ICPSR version. Amherst, MA: University of Massachusetts, Political Economy Research Institute [producer], 2000. Ann Arbor, MI: Interuniversity Consortium for Political and Social Research [distributor]. 
—. 2001. China's Retreat from Equality - Income Distribution and Economic Transition. London: M.E. Sharpe.

Rozelle, Scott, Xiaoyuan Dong, Linxiu Zhang, and Andrew Mason. 2002. Gender wage gaps in post-reform rural China. Pacific Economic Review 7(1): 157-179.

Zhao, Yaohui. 2001. Foreign direct investment and relative wages: The case of China. China Economic Review 12(1): 40-57.

- 2002. Earnings differentials between State and Non-State Enterprises in Urban China. Pacific Economic Review 7(1):181-197.

Zhang, Junsen, Yaohui Zhao, Albert Park, and Xiaoqing Song. 2005. Economic returns to schooling in urban China, 1988 to 2001. Journal of Comparative Economics 33:730-752. 


\section{Table 1 - Main steps in China's urban labor market reform}

\begin{tabular}{|c|c|}
\hline 1978 & $\begin{array}{l}\text { Introduction of a retirement system in urban areas ( } 60 \text { years old for men / } 50 \text { years } \\
\text { old for women with no less } 10 \text { years of working experience). }{ }^{29}\end{array}$ \\
\hline 1979 & Reintroduction of bonuses and piece wages to improve labor productivity. \\
\hline 1982 & Encouragement of development of self-employment and individual firms ${ }^{30}$. \\
\hline 1983 & $\begin{array}{l}\text { Introduction of the labor contract system to cover new entrants into state and } \\
\text { collective sectors. } \\
\text { Introduction of a "job-holding without pay" scheme. }\end{array}$ \\
\hline 1984 & $\begin{array}{l}\text { More authority given to enterprises to determine wage and introduction of a floating } \\
\text { wage system linked to enterprise performance and profitability. }{ }^{32}\end{array}$ \\
\hline 1986 & $\begin{array}{l}\text { New regulations promulgated, including Temporary Regulations on Labor Contract } \\
\text { System of State-owned Enterprises, Temporary Regulations on Dismissal of } \\
\text { Lawbreaking Worker in State-owned Enterprises, Temporary Regulations on State- } \\
\text { owned Enterprises Workers, Temporary Regulations on State-owned Enterprises } \\
\text { Recruitment of Workers, Temporary Regulations on Laid-off Workers of State-owned } \\
\text { Enterprises. } \\
\text { Law enabling enterprises to lay-off employees. } \\
\text { Launching of an unemployment insurance scheme (July). }\end{array}$ \\
\hline 1987 & $\begin{array}{l}\text { New regulations on fixed-term contracts, calling for the extension of contracts to } \\
\text { incumbent workers. }\end{array}$ \\
\hline 1990 & $\begin{array}{l}\text { Restrictions on migration of rural labor force to reduce employment pressure in } \\
\text { urban areas. }\end{array}$ \\
\hline 1991 & Reform of the pension system. ${ }^{34}$ \\
\hline 1992 & $\begin{array}{l}\text { Labor Union Law (April). } \\
\text { More authority given to state-owned enterprises in the manufacturing sector in terms } \\
\text { of recruitment and lay-off of workers as well as in setting wages and bonuses. }{ }^{35}\end{array}$ \\
\hline 1993 & $\begin{array}{l}\text { Regulations on Reallocation of Surplus Staff and Workers of State-Owned } \\
\text { Enterprises, to define layoff (xiagang) conditions (firing procedures, amount of } \\
\text { retired money, etc.). } \\
\text { Regulations on the Minimum Wage of State-Owned Enterprises (November). }\end{array}$ \\
\hline 1994 & $\begin{array}{l}\text { Regulations on bankruptcy of state-owned enterprises and setting-up of re- } \\
\text { employment centers. } \\
\text { Introduction of rules on interregional movement of rural labor force, including a }\end{array}$ \\
\hline
\end{tabular}

${ }^{29}$ See State Council's Provisional Measures for Retirement and Quit of Workers, issued on June 2, 1978.

${ }^{30}$ Sixth Five-Year Plan of China Economic and Social Development, ratified by the People's Congress on December 10, 1982.

${ }^{31}$ See Statement of the Ministry of Personnel and Labor on Active Implementation of Labor Contract, issued on February 22, 1983.

${ }^{32}$ The Central Committee of Chinese Communist Party's Resolution on Economic Institutional Reform, issued on October 20, 1984.

${ }^{33}$ See State Council's Notice on Effective Work for Urban Employment, issued on April 27, 1990.

${ }^{34}$ See State Council's Resolution on Reform of Pension System for Enterprise Workers, issued on June 26, 1991.

${ }^{35}$ See Regulations on Transform of Operation Mechanism of State-owned Industrial Enterprises, issued by the State Council on July 23, 1992. 


\begin{tabular}{|c|c|}
\hline & $\begin{array}{l}\text { number of cards such as the Employment Card and the Temporary Resident Card. }{ }^{37} \\
\text { Regulations on Wage Control of Joint-Stock Companies (December). }\end{array}$ \\
\hline 1995 & $\begin{array}{l}\text { Labor Law of the PRC (effective on Jan. } 1^{\text {st }} \text { ), making labor contracts mandatory in all } \\
\text { industrial enterprises, including TVEs. } \\
\text { Working time legally set at no more than eight hours a day and no more than } 44 \\
\text { hours a week on average in the state sector. } \\
\text { Implementation of the re-employment project, providing preferential policy for firms } \\
\text { employing unemployed workers and surplus laborers. }\end{array}$ \\
\hline 1997 & Acceleration in the implementation of the laid-off policy. ${ }^{40}$ \\
\hline 1998 & $\begin{array}{l}\text { Introduction of new re-employment policies such as encouraging development of } \\
\text { private and individual enterprises, tax exemptions for firms employing laid-off } \\
\text { workers. }{ }^{41} \\
\text { Regulations issued by the Ministry of Public Security to loosen the control on hukou } \\
\text { registration. }\end{array}$ \\
\hline 1999 & $\begin{array}{l}\text { Regulations on Unemployment Insurance, to help transform the laid-off subsidy } \\
\text { system into an unemployment insurance system. } \\
\text { Regulations on Security of Minimum Livelihood for Urban Residents, to provide } \\
\text { income program for poor urban households (September). }\end{array}$ \\
\hline 2000 & $\begin{array}{l}\text { More authority given to enterprises in wage setting and allowing managers to set } \\
\text { higher wage for themselves. }{ }^{42} \\
\text { Provisional Regulations on Collective Negotiation in Wage Setting (issued by } \\
\text { MOLSS, November). }\end{array}$ \\
\hline 2001 & Pilot implementation of the New Social Security Scheme in some cities. ${ }^{43}$ \\
\hline 2003 & $\begin{array}{l}\text { Drop of some restrictions to rural-urban migration, including abolishment of various } \\
\text { cards and fees charged on migrant workers. }{ }^{44}\end{array}$ \\
\hline
\end{tabular}

Sources: Cai (2005), Fleisher and Yang (2003), Meng (2000), MOLSS and Literature Research Office of CCCPC (2002), Zhang et al. (2005).

\footnotetext{
${ }^{36}$ See State Council's Notice on Some Issues Related to Trial Implementation of Bankruptcy for Stateowned Enterprises in Selected Cities, November 25, 1994.

${ }^{37}$ See Provisional Regulations on Employment of Rural Labor Force between Provinces, issued by the Ministry of Labor, November 17, 1994.

${ }^{38}$ See State Council's Regulations on Work Time of Workers, issued on March 25, 1995.

${ }^{39}$ See Report of the Ministry of Labor on Implementation of the Re-employment Project, Submitted to the State Council on March 27, 1995.

${ }^{40}$ See State Council's Complementary Notice on Some Issues Related to Trial Implementation of Merge and Bankruptcy for State-owned Enterprises and Re-employment of Workers in Selected Cities, March 2, 1997.

${ }^{41}$ See CCCPC and State Council's Notice on Security of Basic Livelihood of Laid-off Workers from State-owned Enterprises and Emphasis on Re-employment, June 9, 1998.

${ }^{42}$ See Guidelines for Further Deepening Distribution System in Enterprises, issued by the MOLSS, November 6, 2000.

${ }^{43}$ See State Council's Complementary Notice on Pilot Plan for Perfecting Social Security System in Urban Areas, December 25, 2000.

${ }^{44}$ See Notice on Better Services and Management of Employment for Rural-Urban Migrant Workers, issued by the State Council, January 5, 2003.
} 
Table 2 - Distribution of sampled households for urban surveys (1995 and 2002)

\begin{tabular}{l|l|l|l|l}
\hline \multirow{2}{*}{ Province } & \multicolumn{2}{|l|}{1995} & \multicolumn{2}{l}{2002} \\
\cline { 2 - 5 } & Number of cities & $\begin{array}{l}\text { Number of } \\
\text { sampled } \\
\text { households }\end{array}$ & Number of cities & $\begin{array}{l}\text { Number of } \\
\text { sampled } \\
\text { households }\end{array}$ \\
\hline Beijing & 1 & 500 & 1 & 500 \\
Shanxi & 7 & 650 & 7 & 650 \\
Liaoning & 5 & 700 & 5 & 700 \\
Jiangsu & 9 & 800 & 9 & 750 \\
Anhui & 6 & 500 & 6 & 500 \\
Henan & 8 & 600 & 8 & 700 \\
Hubei & 7 & 742 & 7 & 700 \\
Guangdong & 8 & 546 & 8 & 550 \\
Chongqing & - & - & 2 & 600 \\
Sichuan & 7 & 848 & 6 & 650 \\
Yunnan & 9 & 648 & 6000 \\
Gansu & 3 & 400 & 6,934 & 300 \\
Total & 69 & &
\end{tabular}

Source: 1995 and 2002 CHIP survey data. 
Table 3 - Correlation between the three segments

\subsection{Ownership / Sector}

1995

\begin{tabular}{|c|c|c|c|c|c|}
\hline Ownership & $\begin{array}{l}\text { Sector } \\
\text { Competitive }\end{array}$ & Oligopolistic & $\begin{array}{l}\text { Public } \\
\text { service }\end{array}$ & Government & Total \\
\hline \multirow[t]{2}{*}{ SOEs } & 88.45 & 4.49 & 4.93 & 2.14 & 100 \\
\hline & 69.85 & 38.04 & 16.62 & 9.19 & 52.26 \\
\hline \multirow[t]{2}{*}{ UCEs } & 91.51 & 6.05 & 2.44 & 0 & 100 \\
\hline & 21.11 & 14.99 & 2.41 & 0 & 15.26 \\
\hline \multirow[t]{2}{*}{ PIEs } & 84.15 & 12.57 & 3.28 & 0 & 100 \\
\hline & 2.07 & 3.31 & 0.34 & 0 & 1.62 \\
\hline \multirow[t]{2}{*}{ FIEs } & 94.7 & 4.55 & 0.76 & 0 & 100 \\
\hline & 1.68 & 0.86 & 0.06 & 0 & 1.17 \\
\hline \multirow[t]{2}{*}{ GAIs } & 11.82 & 8.88 & 42.06 & 37.24 & 100 \\
\hline & 5.3 & 42.8 & 80.57 & 90.81 & 29.68 \\
\hline \multirow[t]{2}{*}{ Total } & 66.17 & 6.16 & 15.49 & 12.17 & 100 \\
\hline & 100 & 100 & 100 & 100 & 100 \\
\hline
\end{tabular}

2002

\begin{tabular}{|c|c|c|c|c|c|}
\hline Ownership & $\begin{array}{l}\text { Sector } \\
\text { Competitive }\end{array}$ & Oligopolistic & $\begin{array}{l}\text { Public } \\
\text { service }\end{array}$ & Government & Total \\
\hline SOES & $\begin{array}{l}82.41 \\
49.39\end{array}$ & $\begin{array}{l}10.2 \\
58.01\end{array}$ & $\begin{array}{l}5.68 \\
9.2\end{array}$ & $\begin{array}{l}1.71 \\
3.75 \\
\end{array}$ & $\begin{array}{l}100 \\
34.28\end{array}$ \\
\hline UCEs & $\begin{array}{l}90 \\
10.92 \\
\end{array}$ & $\begin{array}{l}4.51 \\
5.19 \\
\end{array}$ & $\begin{array}{l}5.49 \\
1.8 \\
\end{array}$ & $\begin{array}{l}0 \\
0\end{array}$ & $\begin{array}{l}100 \\
6.94\end{array}$ \\
\hline PIEs & $\begin{array}{l}91.03 \\
33.1 \\
\end{array}$ & $\begin{array}{l}4.78 \\
16.48 \\
\end{array}$ & $\begin{array}{l}4.19 \\
4.12 \\
\end{array}$ & $\begin{array}{l}0 \\
0\end{array}$ & $\begin{array}{l}100 \\
20.79\end{array}$ \\
\hline FIEs & $\begin{array}{l}84.49 \\
3.76 \\
\end{array}$ & $\begin{array}{l}7.49 \\
3.16 \\
\end{array}$ & $\begin{array}{l}8.02 \\
0.96 \\
\end{array}$ & $\begin{array}{l}0 \\
0\end{array}$ & $\begin{array}{l}100 \\
2.54 \\
\end{array}$ \\
\hline GAIs & $\begin{array}{l}4.57 \\
2.83 \\
\end{array}$ & $\begin{array}{l}2.92 \\
17.16 \\
\end{array}$ & $\begin{array}{l}50.12 \\
83.92 \\
\end{array}$ & $\begin{array}{l}42.4 \\
96.25 \\
\end{array}$ & $\begin{array}{l}100 \\
35.44 \\
\end{array}$ \\
\hline Total & $\begin{array}{l}57.2 \\
100\end{array}$ & $\begin{array}{l}6.03 \\
100\end{array}$ & $\begin{array}{l}21.16 \\
100\end{array}$ & $\begin{array}{l}15.61 \\
100\end{array}$ & $\begin{array}{l}100 \\
100\end{array}$ \\
\hline
\end{tabular}




\subsection{Ownership / Region}

1995

\begin{tabular}{l|lllll|l}
\hline \multirow{2}{*}{ Ownership } & Coast & Center & $\begin{array}{l}\text { Region } \\
\text { West }\end{array}$ & Municipality & Northeast & Total \\
\hline SOEs & 17.07 & 35.68 & 27.21 & 7.8 & 12.24 & 100 \\
& 46.68 & 55.15 & 53.39 & 58.31 & 60.41 & 53.8 \\
\hline UCEs & 28.83 & 31.91 & 24.05 & 3.47 & 11.73 & 100 \\
& 20.89 & 13.07 & 12.5 & 6.88 & 15.34 & 14.26 \\
\hline PIEs & 50 & 22.62 & 19.05 & 3.57 & 4.76 & 100 \\
& 1.99 & 0.51 & 0.55 & 0.39 & 0.34 & 0.78 \\
\hline FIEs & 55.07 & 10.87 & 13.77 & 12.32 & 7.97 & 100 \\
& 3.61 & 0.4 & 0.65 & 2.21 & 0.94 & 1.29 \\
\hline GAIs & 17.67 & 35.97 & 30.22 & 7.76 & 8.38 & 100 \\
& 26.83 & 30.86 & 32.91 & 32.21 & 22.96 & 29.87 \\
\hline Total & 19.67 & 34.81 & 27.42 & 7.19 & 10.9 & 100 \\
& 100 & 100 & 100 & 100 & 100 & 100 \\
\hline
\end{tabular}

2002

\begin{tabular}{|c|c|c|c|c|c|c|}
\hline Ownership & Coast & Center & $\begin{array}{l}\text { Region } \\
\text { West }\end{array}$ & Municipality & Northeast & Total \\
\hline \multirow[t]{2}{*}{ SOEs } & 17.32 & 36.61 & 25.22 & 8.93 & 11.93 & 100 \\
\hline & 33.49 & & 34.76 & 40.95 & 40.48 & 37.12 \\
\hline \multirow[t]{2}{*}{ UCEs } & 25.96 & 26.55 & 24.48 & 4.57 & 18.44 & 100 \\
\hline & 10.09 & 5.69 & 6.79 & 4.22 & 12.59 & 7.47 \\
\hline \multirow[t]{2}{*}{ PIEs } & 23.83 & 30.96 & 26.94 & 5.38 & 12.9 & 100 \\
\hline & 24.14 & 17.29 & 19.47 & 12.93 & 22.96 & 19.46 \\
\hline \multirow[t]{2}{*}{ FIEs } & 30.33 & 22.27 & 12.32 & 25.59 & 9.48 & 100 \\
\hline & 3.67 & 1.49 & 1.06 & 7.35 & 2.01 & 2.32 \\
\hline \multirow[t]{2}{*}{ GAIs } & 16.34 & 37.85 & 30.35 & 8.32 & 7.14 & 100 \\
\hline & 28.61 & 36.54 & 37.91 & 34.56 & 21.95 & 33.63 \\
\hline \multirow[t]{2}{*}{ Total } & 19.2 & 34.84 & 26.92 & 8.09 & 10.93 & 100 \\
\hline & 100 & 100 & 100 & 100 & 100 & 100 \\
\hline
\end{tabular}




\subsection{Sector / Region}

1995

\begin{tabular}{l|lllll|l}
\hline \multirow{2}{*}{ Sector } & Coast & Center & $\begin{array}{l}\text { Region } \\
\text { West }\end{array}$ & Municipality & Northeast & Total \\
\hline Competitive & 20.81 & 35.47 & 27.01 & 5.74 & 10.98 & 100 \\
& 69.52 & 65.08 & 65.45 & 59.13 & 72.89 & 66.46 \\
\hline Oligop. & 25.1 & 33.47 & 23.85 & 7.67 & 9.9 & 100 \\
& 7.89 & 5.78 & 5.44 & 7.44 & 6.19 & 6.26 \\
\hline Public serv. & 17.65 & 36.09 & 28.84 & 8.79 & 8.62 & 100 \\
& 13.55 & 15.22 & 16.07 & 20.84 & 13.16 & 15.28 \\
\hline Government & 14.97 & 42.01 & 29.8 & 6.76 & 6.47 & 100 \\
& 9.04 & 13.92 & 13.04 & 12.58 & 7.76 & 12.01 \\
\hline Total & 19.89 & 36.23 & 27.42 & 6.45 & 10.01 & 100 \\
& 100 & 100 & 100 & 100 & 100 & 100 \\
\hline
\end{tabular}

2002

\begin{tabular}{l|lllll|l}
\hline \multirow{2}{*}{ Sector } & Coast & Center & $\begin{array}{l}\text { Region } \\
\text { West }\end{array}$ & Municipality & Northeast & Total \\
\hline Competitive & 21.54 & 34.92 & 27.6 & 5.94 & 10 & 100 \\
& 65.34 & 54.41 & 56.75 & 46.91 & 62.63 & 57.34 \\
\hline Oligop. & 15.96 & 46.12 & 19.07 & 8.2 & 10.64 & 100 \\
& 5.03 & 7.47 & 4.07 & 6.73 & 6.93 & 5.96 \\
\hline Public serv. & 15.79 & 40.88 & 27.23 & 8.49 & 7.61 & 100 \\
& 17.54 & 23.33 & 20.51 & 24.55 & 17.46 & 21 \\
\hline Government & 14.55 & 34.65 & 33.14 & 10.09 & 7.57 & 100 \\
& 12.09 & 14.79 & 18.66 & 21.82 & 12.99 & 15.7 \\
\hline Total & 18.9 & 36.8 & 27.88 & 7.26 & 9.15 & 100 \\
& 100 & 100 & 100 & 100 & 100 & 100 \\
\hline
\end{tabular}

Source: Authors' calculations using the 1995 and 2002 CHIP survey data. 
Table 4: Descriptive statistics on individual characteristics by ownership

\begin{tabular}{lllllll}
\hline $\mathbf{1 9 9 5}$ & All & SOEs & UCEs & PIEs & FIEs & GAIs \\
\hline \# obs. & 10,730 & 5,775 & 1,534 & 84 & 138 & 3,199 \\
\% & 100 & 53.82 & 14.30 & 0.78 & 1.29 & 29.81 \\
& & & & & & \\
Male (\%) & 53.34 & 55.83 & 40.81 & 52.38 & 54.35 & 54.83 \\
Age & 38.39 & 38.42 & 38.02 & 32.07 & 30.96 & 39.00 \\
Years of education & 10.79 & 10.47 & 9.25 & 9.29 & 11.07 & 12.15 \\
Communist (\%) & 25.12 & 21.51 & 11.54 & 4.76 & 10.14 & 39.32 \\
Coast (\%) & 26.91 & 24.92 & 32.40 & 53.57 & 67.39 & 25.41 \\
Long term tenure (\%) & 96.32 & 98.32 & 92.12 & 7.50 & 59.26 & 98.57 \\
\hline & & & & & & \\
\hline 2002 & All & SOEs & UCEs & PIEs & FIEs & GAIs \\
\hline \# obs. & 9,081 & 3,371 & 678 & 1,767 & 211 & 3,054 \\
\% & 100 & 37.12 & 7.47 & 19.46 & 2.32 & 33.63 \\
& & & & & & \\
Male (\%) & 56.69 & 60.99 & 43.51 & 55.80 & 59.24 & 55.21 \\
Age & 40.41 & 41.17 & 41.36 & 38.58 & 35.15 & 40.78 \\
Years of education & 11.52 & 11.18 & 10.06 & 10.48 & 12.30 & 12.75 \\
Communist (\%) & 29.88 & 28.36 & 19.32 & 14.20 & 14.22 & 44.04 \\
Coast (\%) & 27.30 & 26.25 & 30.53 & 29.20 & 55.92 & 24.66 \\
Long term tenure (\%) & 77.11 & 88.42 & 72.57 & 38.17 & 56.40 & 89.64 \\
\hline
\end{tabular}

Source: Authors' calculations using the 1995 and 2002 CHIP survey data.

Notes:

1. The sample includes individuals aged 16 to 60 , who declared working at least a part of the year and earning (positive) wages. Owners of private or individual enterprises are not considered.

2. Education and Experience are the number of years of education and work experience declared by the respondent.

3. “Coast” dummy includes Beijing, Guangdong, and Jiangsu.

4. Long-term tenure includes both permanent workers and long-term contract workers, as opposed to temporary or short-term contract workers.

5. Ownership categories are: state-owned enterprises (SOEs), urban collective enterprises (UCEs), private or individual enterprises, (PIEs), foreign-invested enterprises (FIEs), and government agencies or institutions (GAIs).

6. Tables for different dimensions (ownership, sector and regions) may show slightly different average total values and due to attrition on categorical variables. 
Table 5: Descriptive statistics on individual characteristics by sectors

\begin{tabular}{llllll}
\hline 1995 & All & Competitive & Oligopolistic & Public services & Government \\
\hline \# obs & 9,665 & 6,343 & 607 & 1,466 & 1,249 \\
\% & 100 & 65.63 & 6.28 & 15.17 & 12.92 \\
Male (\%) & & & & & \\
Age & 52.42 & 52.40 & 48.60 & 46.04 & 61.81 \\
Years of education & 38.33 & 38.00 & 36.08 & 40.21 & 38.89 \\
Communist (\%) & 10.78 & 10.16 & 10.68 & 12.32 & 12.18 \\
SOE (\%) & 24.80 & 18.97 & 22.73 & 28.17 & 51.48 \\
Coast (\%) & 81.95 & 75.07 & 81.38 & 97.41 & 98.96 \\
Long term tenure (\%) & 26.93 & 27.29 & 33.77 & 26.74 & 22.02 \\
\hline 2002 & 96.24 & 95.60 & 92.32 & 98.89 & 98.30 \\
\hline \# obs & All & Competitive & Oligopolistic & Public services & Government \\
\% & 8,195 & 4,752 & 706 & 1,560 & 1,177 \\
& 100 & 57.99 & 8.62 & 19.04 & 14.36 \\
Male (\%) & & & & & \\
Age & 54.31 & 52.61 & 58.50 & 50.32 & 63.98 \\
Years of education & 11.57 & 10.69 & 11.87 & 13.07 & 41.20 \\
Communist (\%) & 30.24 & 21.74 & 29.04 & 34.17 & 60.07 \\
SOE (\%) & 74.92 & 61.99 & 86.54 & 93.27 & 95.84 \\
Coast (\%) & 27.41 & 28.83 & 28.33 & 24.55 & 24.89 \\
Long term tenure (\%) & 74.44 & 64.80 & 81.59 & 89.87 & 88.73 \\
\hline SOur Aur
\end{tabular}

Source: Authors' calculations using the 1995 and 2002 CHIP survey data.

Notes:

1. See Table 4.

2. See text for a full definition of sectors.

3. The lower number of observation is due to the omission of unclear sectors. See text for details. 
Table 6: Descriptive statistics on individual characteristics by regions

\begin{tabular}{|c|c|c|c|c|c|c|}
\hline 1995 & All & Coast & Center & West & Municipality & Northeast \\
\hline \# obs & 10,898 & 2,170 & 3,778 & 2,991 & 779 & 1,180 \\
\hline$\%$ & 100 & 19.91 & 34.67 & 27.45 & 7.15 & 10.83 \\
\hline Male (\%) & 53.18 & 53.13 & 53.81 & 51.92 & 54.30 & 53.73 \\
\hline Age & 38.37 & 38.45 & 37.52 & 38.71 & 40.24 & 38.87 \\
\hline Years of education & 10.78 & 10.48 & 10.76 & 10.71 & 11.86 & 10.87 \\
\hline Communist (\%) & 25.00 & 23.64 & 24.80 & 26.38 & 31.19 & 20.51 \\
\hline SOE (\%) & 82.35 & 71.57 & 85.07 & 84.75 & 89.73 & 82.46 \\
\hline Long term tenure (\%) & 96.14 & 92.86 & 97.21 & 96.72 & 95.45 & 97.69 \\
\hline 2002 & All & Coast & Center & West & Municipality & Northeast \\
\hline \# obs & 9,537 & 1,812 & 3,300 & 2,576 & 799 & 1,050 \\
\hline$\%$ & 100 & 19.00 & 34.60 & 27.01 & 8.38 & 11.01 \\
\hline Male (\%) & 56.09 & 54.86 & 57.06 & 55.16 & 54.07 & 58.95 \\
\hline Age & 40.38 & 40.57 & 39.58 & 40.54 & 42.46 & 40.58 \\
\hline Years of education & 11.50 & 11.33 & 11.61 & 11.26 & 12.26 & 11.44 \\
\hline Communist (\%) & 29.62 & 28.81 & 30.18 & 30.55 & 29.29 & 27.24 \\
\hline SOE (\%) & 75.23 & 70.09 & 79.33 & 77.76 & 77.60 & 63.24 \\
\hline Long term tenure (\%) & 74.87 & 69.87 & 80.92 & 76.99 & 68.46 & 64.29 \\
\hline
\end{tabular}

Source: Authors' calculations using the 1995 and 2002 CHIP survey data.

Notes:

4. See Table 4.

5. See text for a full definition of regions. 
Table 7: Descriptive statistics on individual characteristics by ownership

\begin{tabular}{|c|c|c|c|c|c|c|}
\hline 1995 & All & SOEs & UCES & PIEs & FIEs & GAIs \\
\hline Total annual earnings & 6,155 & 6,178 & 4,878 & 5,199 & 8,148 & 6,667 \\
\hline c.v. & 0.51 & 0.51 & 0.57 & 0.81 & 0.74 & 0.45 \\
\hline Gap to average earnings & & 1.00 & 0.79 & 0.84 & 1.32 & 1.08 \\
\hline Basic wage & 3,821 & 3,833 & 3,240 & 4,614 & 6,531 & 3,942 \\
\hline c.v. & 0.56 & 0.53 & 0.59 & 0.89 & 0.92 & 0.49 \\
\hline Bonus & 983 & 1,067 & 703 & 257 & 847 & 991 \\
\hline c.v. & 1.64 & 1.58 & 2.14 & 5.19 & 1.86 & 1.55 \\
\hline Subsidies & 1,115 & 1,032 & 627 & 76 & 460 & 1,556 \\
\hline c.v. & 1.07 & 0.98 & 1.16 & 3.50 & 1.91 & 0.97 \\
\hline Income in kind & 99 & 99 & 69 & 105 & 86 & 113 \\
\hline c.v. & 2.72 & 2.62 & 3.76 & 4.56 & 2.53 & 2.49 \\
\hline Hourly wage & 2.89 & 2.88 & 2.36 & 1.96 & 3.45 & 3.15 \\
\hline c.v. & 0.65 & 0.66 & 0.82 & 0.86 & 0.73 & 0.54 \\
\hline Hours worked per week & 43.7 & 44.0 & 43.5 & 56.6 & 47.2 & 42.8 \\
\hline c.v. & 0.17 & 0.16 & 0.23 & 0.27 & 0.19 & 0.15 \\
\hline 2002 & All & SOEs & UCES & PIES & FIEs & GAIs \\
\hline Total annual earnings & 11,071 & 10,840 & 7,630 & 8,286 & 13,305 & 13,547 \\
\hline c.v. & 0.66 & 0.62 & 0.61 & 0.92 & 0.66 & 0.53 \\
\hline Gap to average earnings & & 0.98 & 0.69 & 0.75 & 1.20 & 1.22 \\
\hline Basic wage & 9,128 & 8,985 & 6,709 & 7,141 & 11,081 & 10,838 \\
\hline c.v. & 0.63 & 0.58 & 0.59 & 0.89 & 0.61 & 0.53 \\
\hline Bonus & 1,049 & 1,149 & 549 & 595 & 1,372 & 1,290 \\
\hline c.v. & 2.41 & 2.23 & 3.75 & 3.40 & 2.12 & 2.15 \\
\hline Subsidies & 673 & 526 & 255 & 166 & 524 & 1,231 \\
\hline c.v. & 2.94 & 2.93 & 3.40 & 4.36 & 4.01 & 2.26 \\
\hline Income in kind & 130 & 119 & 94 & 139 & 333 & 131 \\
\hline c.v. & 7.68 & 6.81 & 3.11 & 11.19 & 9.02 & 3.43 \\
\hline Hourly wage & 5.38 & 5.31 & 3.64 & 3.66 & 6.16 & 6.79 \\
\hline c.v. & 0.88 & 0.84 & 0.66 & 1.08 & 0.71 & 0.79 \\
\hline Hours worked per week & 43.7 & 42.3 & 43.5 & 50.1 & 44.6 & 41.4 \\
\hline c.v. & 0.23 & 0.19 & 0.23 & 0.29 & 0.22 & 0.19 \\
\hline
\end{tabular}

Source: Authors’ calculations using the 1995 and 2002 CHIP survey data.

Notes:

1. The sample includes individuals aged 16 to 60 , who declared working at least a part of the year and earning (positive) wages. Owners of private or individual enterprises are not considered.

2. The earnings variable is defined as the sum of the basic wage, bonuses, allowances and subsidies, other wages, and income in kind.

3. Earnings are deflated using the urban provincial-level spatial price deflators calculated by Brandt and Holz (2006). Base = nationwide prices in 2002.

4. The gap to average earnings is calculated as average total earnings for enterprise category $i$ divided by average total earnings for all categories of enterprises (reported in column 1).

5. Ownership categories are: state-owned enterprises (SOEs), urban collective enterprises (UCEs), private or individual enterprises, (PIEs), foreign-invested enterprises (FIEs), and government agencies or institutions (GAIs).

6. C.V. = coefficient of variation 
Table 8: Descriptive statistics on individual characteristics by economic sectors

\begin{tabular}{|c|c|c|c|c|c|}
\hline 1995 & All & Competitive & Oligopolistic & Public services & Government \\
\hline Total annual earnings & 6,089 & 5,824 & 6,428 & 6,815 & 6,419 \\
\hline c.v. & 0.51 & 0.52 & 0.59 & 0.41 & 0.47 \\
\hline Gap to average earnings & & 0.96 & 1.06 & 1.12 & 1.05 \\
\hline Basic wage & 3,792 & 3,740 & 3,624 & 4,038 & 3,848 \\
\hline c.v. & 0.55 & 0.57 & 0.58 & 0.48 & 0.49 \\
\hline Bonus & 961 & 929 & 1,354 & 1,005 & 886 \\
\hline c.v. & 1.66 & 1.68 & 1.81 & 1.33 & 1.69 \\
\hline Subsidies & 1,098 & 889 & 1,243 & 1,597 & 1,503 \\
\hline c.v. & 1.07 & 1.03 & 1.20 & 0.88 & 1.02 \\
\hline Income in kind & 99 & 91 & 113 & 105 & 123 \\
\hline c.v. & 2.76 & 2.93 & 2.37 & 2.81 & 2.23 \\
\hline Hourly wage & 2.85 & 2.73 & 2.97 & 3.23 & 3.00 \\
\hline c.v. & 0.63 & 0.67 & 0.69 & 0.52 & 0.52 \\
\hline Hours worked per week & 43.7 & 43.9 & 44.3 & 42.9 & 43.1 \\
\hline c.v. & 0.17 & 0.18 & 0.18 & 0.15 & 0.15 \\
\hline 2002 & All & Competitive & Oligopolistic & Public services & Government \\
\hline Total annual earnings & 10,910 & 8,860 & 13,086 & 14,410 & 13,245 \\
\hline c.v. & 0.67 & 0.71 & 0.66 & 0.56 & 0.49 \\
\hline Gap to average earnings & & 0.81 & 1.20 & 1.32 & 1.21 \\
\hline Basic wage & 8,959 & 7,544 & 10,534 & 11,069 & 10,930 \\
\hline c.v. & 0.64 & 0.69 & 0.61 & 0.53 & 0.52 \\
\hline Bonus & 1,036 & 777 & 1,514 & 1,601 & 1,042 \\
\hline c.v. & 2.46 & 2.84 & 2.20 & 1.98 & 2.08 \\
\hline Subsidies & 672 & 327 & 730 & 1,207 & 1,320 \\
\hline c.v. & 2.96 & 3.65 & 2.94 & 2.18 & 2.21 \\
\hline Income in kind & 132 & 101 & 309 & 120 & 165 \\
\hline c.v. & 7.90 & 7.22 & 9.12 & 3.74 & 3.54 \\
\hline Hourly wage & 5.30 & 4.13 & 6.41 & 7.33 & 6.64 \\
\hline c.v. & 0.87 & 0.81 & 0.69 & 0.93 & 0.63 \\
\hline Hours worked per week & 43.8 & 45.5 & 41.6 & 41.7 & 41.1 \\
\hline c.v. & 0.24 & 0.26 & 0.18 & 0.20 & 0.18 \\
\hline
\end{tabular}

Source: Authors' calculations using the 1995 and 2002 CHIP survey data.

Notes:

1. See table 7.

2. See text for definitions of economic sectors. 
Table 9: Descriptive statistics on individual characteristics by regions

\begin{tabular}{|c|c|c|c|c|c|c|}
\hline 1995 & All & Coast & Center & West & Municipality & Northeast \\
\hline Total annual earnings & 6,151 & 7,558 & 5,409 & 5,851 & 7,495 & 5,812 \\
\hline c.v. & 0.51 & 0.55 & 0.47 & 0.44 & 0.48 & 0.49 \\
\hline Gap to average earnings & & 1.23 & 0.88 & 0.95 & 1.22 & 0.94 \\
\hline Basic wage & 3,824 & 4,072 & 3,656 & 3,693 & 4,366 & 3,874 \\
\hline c.v. & 0.56 & 0.63 & 0.50 & 0.51 & 0.70 & 0.52 \\
\hline Bonus & 981 & 1,831 & 645 & 773 & 1,558 & 639 \\
\hline c.v. & 1.64 & 1.53 & 1.27 & 1.31 & 1.02 & 1.59 \\
\hline Subsidies & 1,111 & 1,357 & 845 & 1,217 & 1,365 & 1,070 \\
\hline c.v. & 1.07 & 1.26 & 1.04 & 0.88 & 0.87 & 0.93 \\
\hline Income in kind & 99 & 108 & 115 & 78 & 106 & 78 \\
\hline c.v. & 2.72 & 2.85 & 2.32 & 2.76 & 2.75 & 3.84 \\
\hline Hourly wage & 2.89 & 3.54 & 2.56 & 2.74 & 3.43 & 2.71 \\
\hline c.v. & 0.65 & 0.66 & 0.67 & 0.62 & 0.52 & 0.54 \\
\hline Hours worked per week & 43.7 & 44.0 & 43.5 & 43.8 & 43.7 & 43.4 \\
\hline c.v. & 0.17 & 0.19 & 0.18 & 0.16 & 0.16 & 0.16 \\
\hline 2002 & All & Coast & Center & West & Municipality & Northeast \\
\hline Total annual earnings & 10,919 & 13,376 & 9,782 & 10,435 & 12,691 & 10,090 \\
\hline c.v. & 0.66 & 0.75 & 0.61 & 0.57 & 0.62 & 0.62 \\
\hline Gap to average earnings & & 1.23 & 0.90 & 0.96 & 1.16 & 0.92 \\
\hline Basic wage & 9,022 & 10,251 & 8,423 & 8,664 & 10,233 & 8,736 \\
\hline c.v. & 0.64 & 0.72 & 0.58 & 0.59 & 0.71 & 0.58 \\
\hline Bonus & 1,011 & 1,780 & 677 & 878 & 1,396 & 769 \\
\hline c.v. & 2.45 & 2.14 & 2.33 & 2.28 & 2.24 & 2.64 \\
\hline Subsidies & 656 & 1,071 & 361 & 748 & 902 & 454 \\
\hline c.v. & 2.98 & 2.77 & 3.10 & 2.32 & 3.02 & 3.01 \\
\hline Income in kind & 129 & 222 & 129 & 71 & 150 & 97 \\
\hline c.v. & 7.66 & 9.40 & 3.32 & 3.60 & 5.23 & 3.87 \\
\hline Hourly wage & 5.30 & 6.54 & 4.71 & 5.11 & 6.29 & 4.76 \\
\hline c.v. & 0.89 & 0.98 & 0.83 & 0.86 & 0.79 & 0.65 \\
\hline Hours worked per week & 43.8 & 43.7 & 44.3 & 44.1 & 41.3 & 43.8 \\
\hline c.v. & 0.24 & 0.24 & 0.25 & 0.25 & 0.20 & 0.22 \\
\hline
\end{tabular}

Source: Authors' calculations using the 1995 and 2002 CHIP survey data.

Notes:

1. See table 7 .

2. See text for definitions of regional variables. 
Table 10 - Decomposition of observed earnings gaps by ownership

\begin{tabular}{|c|c|c|c|c|c|c|c|c|c|c|c|c|c|c|c|c|c|c|}
\hline \multirow{2}{*}{$\frac{\frac{1995}{(A)}}{\text { SOE }}$} & (B) & & \multicolumn{4}{|c|}{ Observed differences } & \multicolumn{4}{|c|}{ Endowment effect } & \multicolumn{4}{|c|}{ Segmentation effect } & \multicolumn{4}{|c|}{ Hours worked effect } \\
\hline & UCE & $\begin{array}{l}\text { (yuan) } \\
(\%)\end{array}$ & $\begin{array}{l}-1,299 \\
-27 \\
\end{array}$ & $* * *$ & $\begin{array}{l}-1,454 \\
- \\
\end{array}$ & $\begin{array}{l}-1,147 \\
- \\
\end{array}$ & $\begin{array}{l}-352 \\
-7 \\
\end{array}$ & $* * *$ & $\begin{array}{l}-498 \\
-10 \\
\end{array}$ & $\begin{array}{l}-215 \\
-4 \\
\end{array}$ & $\begin{array}{l}-811 \\
-17 \\
\end{array}$ & $* * *$ & $\begin{array}{l}-968 \\
-20 \\
\end{array}$ & $\begin{array}{l}-641 \\
-13 \\
\end{array}$ & $\begin{array}{l}-136 \\
-3 \\
\end{array}$ & $* * *$ & $\begin{array}{l}-241 \\
-5 \\
\end{array}$ & $\begin{array}{l}-56 \\
-1 \\
\end{array}$ \\
\hline SOE & PIE & $\begin{array}{l}\text { (yuan) } \\
(\%)\end{array}$ & $\begin{array}{l}-979 \\
-19 \\
\end{array}$ & $* * *$ & $\begin{array}{l}-1,623 \\
- \\
\end{array}$ & $\begin{array}{l}-189 \\
- \\
\end{array}$ & $\begin{array}{l}-578 \\
-11 \\
\end{array}$ & ns & $\begin{array}{l}-3,950 \\
-79 \\
\end{array}$ & $\begin{array}{l}1,391 \\
28\end{array}$ & $\begin{array}{l}-1,228 \\
-24 \\
\end{array}$ & ns & $\begin{array}{l}-3,692 \\
-74 \\
\end{array}$ & $\begin{array}{l}3,587 \\
69 \\
\end{array}$ & $\begin{array}{l}827 \\
16 \\
\end{array}$ & $*$ & $\begin{array}{l}-502 \\
-10 \\
\end{array}$ & $\begin{array}{l}1,968 \\
39 \\
\end{array}$ \\
\hline SOE & FIE & $\begin{array}{l}\text { (yuan) } \\
(\%)\end{array}$ & $\begin{array}{l}1,970 \\
32 \\
\end{array}$ & $* * *$ & $\begin{array}{l}1,250 \\
- \\
\end{array}$ & $\begin{array}{l}2,797 \\
- \\
\end{array}$ & $\begin{array}{l}303 \\
5 \\
\end{array}$ & ns & $\begin{array}{l}-500 \\
-8 \\
\end{array}$ & $\begin{array}{l}1,500 \\
24 \\
\end{array}$ & $\begin{array}{l}1,394 \\
23 \\
\end{array}$ & $* * *$ & $\begin{array}{l}251 \\
4 \\
\end{array}$ & $\begin{array}{l}2,496 \\
41 \\
\end{array}$ & $\begin{array}{l}273 \\
4 \\
\end{array}$ & $*$ & $\begin{array}{l}-184 \\
-3 \\
\end{array}$ & $\begin{array}{l}606 \\
10 \\
\end{array}$ \\
\hline SOE & GAI & $\begin{array}{l}\text { (yuan) } \\
(\%)\end{array}$ & $\begin{array}{l}490 \\
8 \\
\end{array}$ & $* * *$ & $\begin{array}{l}388 \\
-\quad \\
\end{array}$ & $\begin{array}{l}593 \\
-\quad \\
\end{array}$ & $\begin{array}{l}133 \\
2 \\
\end{array}$ & $* * *$ & $\begin{array}{l}41 \\
1 \\
\end{array}$ & $\begin{array}{l}220 \\
4 \\
\end{array}$ & $\begin{array}{l}532 \\
9 \\
\end{array}$ & $* * *$ & $\begin{array}{l}379 \\
6 \\
\end{array}$ & $\begin{array}{l}656 \\
11 \\
\end{array}$ & $\begin{array}{l}-175 \\
-3 \\
\end{array}$ & $* * *$ & $\begin{array}{l}-234 \\
-4 \\
\end{array}$ & $\begin{array}{l}-120 \\
-2 \\
\end{array}$ \\
\hline UCE & PIE & $\begin{array}{l}\text { (yuan) } \\
(\%)\end{array}$ & $\begin{array}{l}321 \\
7 \\
\end{array}$ & ns & $\begin{array}{l}-309 \\
- \\
\end{array}$ & $\begin{array}{l}1,005 \\
- \\
\end{array}$ & $\begin{array}{l}-485 \\
-10 \\
\end{array}$ & ns & $\begin{array}{l}-5,256 \\
-108 \\
\end{array}$ & $\begin{array}{l}1,492 \\
31 \\
\end{array}$ & $\begin{array}{l}-279 \\
-6 \\
\end{array}$ & ns & $\begin{array}{l}-2,713 \\
-57 \\
\end{array}$ & $\begin{array}{l}4,440 \\
95\end{array}$ & $\begin{array}{l}1,084 \\
22 \\
\end{array}$ & $* * *$ & $\begin{array}{l}146 \\
3 \\
\end{array}$ & $\begin{array}{l}1,952 \\
41 \\
\end{array}$ \\
\hline UCE & FIE & $\begin{array}{l}\text { (yuan) } \\
(\%)\end{array}$ & $\begin{array}{l}3,270 \\
67 \\
\end{array}$ & $* * *$ & $\begin{array}{l}2,572 \\
-\quad \\
\end{array}$ & $\begin{array}{l}4,070 \\
- \\
\end{array}$ & $\begin{array}{l}823 \\
17 \\
\end{array}$ & $* * *$ & $\begin{array}{l}236 \\
5 \\
\end{array}$ & $\begin{array}{l}1,828 \\
38 \\
\end{array}$ & $\begin{array}{l}1,958 \\
40 \\
\end{array}$ & $* * *$ & $\begin{array}{l}1,016 \\
21 \\
\end{array}$ & $\begin{array}{l}2,969 \\
61 \\
\end{array}$ & $\begin{array}{l}490 \\
10 \\
\end{array}$ & $* * *$ & $\begin{array}{l}112 \\
2 \\
\end{array}$ & $\begin{array}{l}845 \\
18 \\
\end{array}$ \\
\hline UCE & GAI & $\begin{array}{l}\text { (yuan) } \\
(\%)\end{array}$ & $\begin{array}{l}1,789 \\
37 \\
\end{array}$ & $* * *$ & $\begin{array}{l}1,648 \\
- \\
\end{array}$ & $\begin{array}{l}1,909 \\
- \\
\end{array}$ & $\begin{array}{l}445 \\
9 \\
\end{array}$ & $* * *$ & $\begin{array}{l}202 \\
4 \\
\end{array}$ & $\begin{array}{l}676 \\
14 \\
\end{array}$ & $\begin{array}{l}1,336 \\
27 \\
\end{array}$ & $* * *$ & $\begin{array}{l}1,069 \\
22 \\
\end{array}$ & $\begin{array}{l}1,595 \\
33 \\
\end{array}$ & $\begin{array}{l}9 \\
0 \\
\end{array}$ & ns & $\begin{array}{l}-117 \\
-2 \\
\end{array}$ & $\begin{array}{l}179 \\
4 \\
\end{array}$ \\
\hline PIE & FIE & $\begin{array}{l}\text { (yuan) } \\
(\%)\end{array}$ & $\begin{array}{l}2,949 \\
57 \\
\end{array}$ & $* * *$ & $\begin{array}{l}2,020 \\
- \\
\end{array}$ & $\begin{array}{l}3,933 \\
- \\
\end{array}$ & $\begin{array}{l}1,712 \\
33 \\
\end{array}$ & ns & $\begin{array}{l}-2,301 \\
-40 \\
\end{array}$ & $\begin{array}{l}5,953 \\
123 \\
\end{array}$ & $\begin{array}{l}1,833 \\
35 \\
\end{array}$ & ns & $\begin{array}{l}-4,521 \\
-89 \\
\end{array}$ & $\begin{array}{l}5,771 \\
118 \\
\end{array}$ & $\begin{array}{l}-596 \\
-12 \\
\end{array}$ & $*$ & $\begin{array}{l}-2,390 \\
-47 \\
\end{array}$ & $\begin{array}{l}1,224 \\
23 \\
\end{array}$ \\
\hline PIE & GAI & $\begin{array}{l}\text { (yuan) } \\
(\%)\end{array}$ & $\begin{array}{l}1,468 \\
28 \\
\end{array}$ & $* * *$ & $\begin{array}{l}678 \\
-\quad \\
\end{array}$ & $\begin{array}{l}2,139 \\
- \\
\end{array}$ & $\begin{array}{l}-640 \\
-12 \\
\end{array}$ & * & $\begin{array}{l}-2,887 \\
-56 \\
\end{array}$ & $\begin{array}{l}3,420 \\
68 \\
\end{array}$ & $\begin{array}{l}3,028 \\
58 \\
\end{array}$ & ** & $\begin{array}{l}-1,649 \\
-40 \\
\end{array}$ & $\begin{array}{l}, 447 \\
109 \\
\end{array}$ & $\begin{array}{l}-919 \\
-18 \\
\end{array}$ & $*$ & $\begin{array}{l}-2,475 \\
-47 \\
\end{array}$ & $\begin{array}{l}634 \\
12 \\
\end{array}$ \\
\hline FIE & GAI & $\begin{array}{l}\text { (yuan) } \\
(\%)\end{array}$ & $\begin{array}{l}-1,481 \\
-22\end{array}$ & $* * *$ & $\begin{array}{l}-2,325 \\
-\end{array}$ & $\begin{array}{l}-749 \\
-\end{array}$ & $\begin{array}{l}-155 \\
-2\end{array}$ & ns & $\begin{array}{l}-1,365 \\
-21\end{array}$ & $\begin{array}{l}1,120 \\
17\end{array}$ & $\begin{array}{l}-943 \\
-14\end{array}$ & $* * *$ & $\begin{array}{l}-2,377 \\
-36\end{array}$ & $\begin{array}{l}-5 \\
0\end{array}$ & $\begin{array}{l}-383 \\
-6\end{array}$ & ns & $\begin{array}{l}-904 \\
-14\end{array}$ & $\begin{array}{l}394 \\
6\end{array}$ \\
\hline
\end{tabular}




\begin{tabular}{|c|c|c|c|c|c|c|c|c|c|c|c|c|c|c|c|c|c|c|}
\hline \multirow{2}{*}{$\frac{\frac{2002}{(A)}}{\text { SOE }}$} & (B) & & \multicolumn{4}{|c|}{ Observed differences } & \multicolumn{4}{|c|}{ Endowment effect } & \multicolumn{4}{|c|}{ Segmentation effect } & \multicolumn{4}{|c|}{ Hours worked effect } \\
\hline & UCE & $\begin{array}{l}\text { (yuan) } \\
(\%)\end{array}$ & $\begin{array}{l}-3,210 \\
-42 \\
\end{array}$ & $* * *$ & $\begin{array}{l}-3,521 \\
- \\
\end{array}$ & $\begin{array}{l}-2,788 \\
- \\
\end{array}$ & $\begin{array}{l}-913 \\
-12 \\
\end{array}$ & $* * *$ & $\begin{array}{l}-1,240 \\
-16 \\
\end{array}$ & $\begin{array}{l}-598 \\
-8 \\
\end{array}$ & $\begin{array}{l}-2,552 \\
-33 \\
\end{array}$ & $* * *$ & $\begin{array}{l}-2,957 \\
-40 \\
\end{array}$ & $\begin{array}{l}-2,119 \\
-27 \\
\end{array}$ & $\begin{array}{l}256 \\
3 \\
\end{array}$ & $* * *$ & $\begin{array}{l}93 \\
1 \\
\end{array}$ & $\begin{array}{l}451 \\
6 \\
\end{array}$ \\
\hline SOE & PIE & $\begin{array}{l}\text { (yuan) } \\
(\%)\end{array}$ & $\begin{array}{l}-2,554 \\
-31 \\
\end{array}$ & $* * *$ & $\begin{array}{l}-2,932 \\
- \\
\end{array}$ & $\begin{array}{l}-2,243 \\
- \\
\end{array}$ & $\begin{array}{l}128 \\
2 \\
\end{array}$ & ns & $\begin{array}{l}-980 \\
-12 \\
\end{array}$ & $\begin{array}{l}1,416 \\
17 \\
\end{array}$ & $\begin{array}{l}-4,163 \\
-50 \\
\end{array}$ & $* * *$ & $\begin{array}{l}-5,861 \\
-72 \\
\end{array}$ & $\begin{array}{l}-2,678 \\
-32 \\
\end{array}$ & $\begin{array}{l}1,481 \\
18 \\
\end{array}$ & $* * *$ & $\begin{array}{l}921 \\
11 \\
\end{array}$ & $\begin{array}{l}2,318 \\
28 \\
\end{array}$ \\
\hline SOE & FIE & $\begin{array}{l}\text { (yuan) } \\
(\%)\end{array}$ & $\begin{array}{l}2,465 \\
23 \\
\end{array}$ & $* * *$ & $\begin{array}{l}1,589 \\
- \\
\end{array}$ & $\begin{array}{l}3,512 \\
- \\
\end{array}$ & $\begin{array}{l}165 \\
2 \\
\end{array}$ & ns & $\begin{array}{l}-802 \\
-7 \\
\end{array}$ & $\begin{array}{l}1,222 \\
11 \\
\end{array}$ & $\begin{array}{l}1,746 \\
16 \\
\end{array}$ & $* * *$ & $\begin{array}{l}610 \\
6 \\
\end{array}$ & $\begin{array}{l}2,770 \\
25 \\
\end{array}$ & $\begin{array}{l}554 \\
5 \\
\end{array}$ & $* * *$ & $\begin{array}{l}97 \\
1 \\
\end{array}$ & $\begin{array}{l}938 \\
9 \\
\end{array}$ \\
\hline SOE & GAI & $\begin{array}{l}\text { (yuan) } \\
(\%) \\
\end{array}$ & $\begin{array}{l}2,707 \\
25 \\
\end{array}$ & $* * *$ & $\begin{array}{l}2,450 \\
- \\
\end{array}$ & $\begin{array}{l}2,998 \\
- \\
\end{array}$ & $\begin{array}{l}411 \\
4 \\
\end{array}$ & $* * *$ & $\begin{array}{l}113 \\
1 \\
\end{array}$ & $\begin{array}{l}727 \\
7 \\
\end{array}$ & $\begin{array}{l}2,476 \\
23 \\
\end{array}$ & $* * *$ & $\begin{array}{l}2,131 \\
19 \\
\end{array}$ & $\begin{array}{l}2,853 \\
26 \\
\end{array}$ & $\begin{array}{l}-180 \\
-2 \\
\end{array}$ & $* * *$ & $\begin{array}{l}-364 \\
-3 \\
\end{array}$ & $\begin{array}{l}-43 \\
0 \\
\end{array}$ \\
\hline UCE & PIE & $\begin{array}{l}\text { (yuan) } \\
(\%)\end{array}$ & $\begin{array}{l}656 \\
9 \\
\end{array}$ & $* * *$ & $\begin{array}{l}279 \\
-\quad \\
\end{array}$ & $\begin{array}{l}1,019 \\
- \\
\end{array}$ & $\begin{array}{l}1,182 \\
16 \\
\end{array}$ & $* * *$ & $\begin{array}{l}544 \\
7 \\
\end{array}$ & $\begin{array}{l}1,849 \\
24 \\
\end{array}$ & $\begin{array}{l}-1,552 \\
-20 \\
\end{array}$ & $* * *$ & $\begin{array}{l}-2,563 \\
-33 \\
\end{array}$ & $\begin{array}{l}-619 \\
-8 \\
\end{array}$ & $\begin{array}{l}1,026 \\
13 \\
\end{array}$ & $* * *$ & $\begin{array}{l}758 \\
10 \\
\end{array}$ & $\begin{array}{l}1,394 \\
18 \\
\end{array}$ \\
\hline UCE & FIE & $\begin{array}{l}\text { (yuan) } \\
(\%)\end{array}$ & $\begin{array}{l}5,675 \\
74 \\
\end{array}$ & $* * *$ & $\begin{array}{l}4,843 \\
- \\
\end{array}$ & $\begin{array}{l}6,953 \\
- \\
\end{array}$ & $\begin{array}{l}1,526 \\
20 \\
\end{array}$ & $* * *$ & $\begin{array}{l}272 \\
4 \\
\end{array}$ & $\begin{array}{l}3,110 \\
41 \\
\end{array}$ & $\begin{array}{l}3,857 \\
51 \\
\end{array}$ & $* * *$ & $\begin{array}{l}2,346 \\
31 \\
\end{array}$ & $\begin{array}{l}5,460 \\
74 \\
\end{array}$ & $\begin{array}{l}292 \\
4 \\
\end{array}$ & $*$ & $\begin{array}{l}-242 \\
-3 \\
\end{array}$ & $\begin{array}{l}948 \\
12 \\
\end{array}$ \\
\hline UCE & GAI & $\begin{array}{l}\text { (yuan) } \\
(\%)\end{array}$ & $\begin{array}{l}5,917 \\
78 \\
\end{array}$ & $* * *$ & $\begin{array}{l}5,567 \\
- \\
\end{array}$ & $\begin{array}{l}6,256 \\
- \\
\end{array}$ & $\begin{array}{l}1,398 \\
18 \\
\end{array}$ & $* * *$ & $\begin{array}{l}638 \\
8 \\
\end{array}$ & $\begin{array}{l}2,140 \\
28 \\
\end{array}$ & $\begin{array}{l}4,952 \\
65 \\
\end{array}$ & $* * *$ & $\begin{array}{l}4,256 \\
55 \\
\end{array}$ & $\begin{array}{l}5,821 \\
77 \\
\end{array}$ & $\begin{array}{l}-433 \\
-6 \\
\end{array}$ & $* * *$ & $\begin{array}{l}-826 \\
-11 \\
\end{array}$ & $\begin{array}{l}-141 \\
-2 \\
\end{array}$ \\
\hline PIE & FIE & $\begin{array}{l}\text { (yuan) } \\
(\%)\end{array}$ & $\begin{array}{l}5,019 \\
61 \\
\end{array}$ & $* * *$ & $\begin{array}{l}4,111 \\
- \\
\end{array}$ & $\begin{array}{l}6,100 \\
- \\
\end{array}$ & $\begin{array}{l}515 \\
6 \\
\end{array}$ & ns & $\begin{array}{l}-1,574 \\
-19 \\
\end{array}$ & $\begin{array}{l}2,342 \\
28 \\
\end{array}$ & $\begin{array}{l}5,403 \\
65 \\
\end{array}$ & $* * *$ & $\begin{array}{l}3,974 \\
47 \\
\end{array}$ & $\begin{array}{l}6,728 \\
81 \\
\end{array}$ & $\begin{array}{l}-899 \\
-11 \\
\end{array}$ & $* * *$ & $\begin{array}{l}-1,811 \\
-22 \\
\end{array}$ & $\begin{array}{l}-338 \\
-4 \\
\end{array}$ \\
\hline PIE & GAI & $\begin{array}{l}\text { (yuan) } \\
(\%)\end{array}$ & $\begin{array}{l}5,261 \\
64 \\
\end{array}$ & $* * *$ & $\begin{array}{l}4,925 \\
-\quad \\
\end{array}$ & $\begin{array}{l}5,683 \\
- \\
\end{array}$ & $\begin{array}{l}543 \\
7 \\
\end{array}$ & ns & $\begin{array}{l}-1,396 \\
-17 \\
\end{array}$ & $\begin{array}{l}2,083 \\
26 \\
\end{array}$ & $\begin{array}{l}6,434 \\
78 \\
\end{array}$ & $* * *$ & $\begin{array}{l}5,452 \\
65 \\
\end{array}$ & $\begin{array}{l}7,490 \\
90 \\
\end{array}$ & $\begin{array}{l}-1,716 \\
-21 \\
\end{array}$ & $* * *$ & $\begin{array}{l}-3,068 \\
-37 \\
\end{array}$ & $\begin{array}{l}-915 \\
-11 \\
\end{array}$ \\
\hline FIE & GAI & $\begin{array}{l}\text { (yuan) } \\
(\%)\end{array}$ & $\begin{array}{l}242 \\
2\end{array}$ & ns & $\begin{array}{l}-957 \\
-\end{array}$ & $\begin{array}{l}1,092 \\
-\end{array}$ & $\begin{array}{l}248 \\
2\end{array}$ & ns & $\begin{array}{l}-1,047 \\
-8\end{array}$ & $\begin{array}{l}1,439 \\
11\end{array}$ & $\begin{array}{l}712 \\
5\end{array}$ & ns & $\begin{array}{l}-631 \\
-5\end{array}$ & $\begin{array}{l}2,189 \\
17\end{array}$ & $\begin{array}{l}-717 \\
-5\end{array}$ & $* * *$ & $\begin{array}{l}-1,321 \\
-10\end{array}$ & $\begin{array}{l}-146 \\
-1\end{array}$ \\
\hline
\end{tabular}

Source: Authors' calculations using the 1995 and 2002 CHIP survey data.

Notes: 1. Percentages are calculated as a percentage of the lowest wage.

2. Decompositions based on regressions results presented in Appendices A and B.

3. Confidence intervals and significance test are derived from a 300 replications bootstrap procedure: * indicates that the estimated effect is statistically significant at

20 percent, ** at 10 percent and *** at 5 percent.

4. Ownership categories are: state-owned enterprises (SOEs), urban collective enterprises (UCEs), private or individual enterprises, (PIEs), foreign-invested

enterprises (FIEs), and government agencies or institutions (GAIs).

5. Earnings are deflated using the urban provincial-level spatial price deflators calculated by Brandt and Holz (2006). Base = nationwide prices in 2002 . 
Table 11 - Decomposition of observed earnings gaps by sectors

\begin{tabular}{|c|c|c|c|c|c|c|c|c|c|c|c|c|c|c|c|c|c|c|}
\hline \multirow{2}{*}{$\begin{array}{l}\underline{1995} \\
\frac{\text { (A) }}{\text { Comp }}\end{array}$} & \multicolumn{2}{|l|}{ (B) } & \multicolumn{4}{|c|}{$\begin{array}{l}\text { Observed differences } \\
\text { (B)- }\end{array}$} & \multicolumn{4}{|c|}{ Endowment effect } & \multicolumn{4}{|c|}{ Segmentation effect } & \multicolumn{4}{|c|}{ Hours worked effect } \\
\hline & Olig & $\begin{array}{l}\text { (yuan) } \\
(\%)\end{array}$ & $\begin{array}{l}604 \\
10 \\
\end{array}$ & $* * *$ & $\begin{array}{l}373 \\
- \\
\end{array}$ & $\begin{array}{l}880 \\
- \\
\end{array}$ & $\begin{array}{l}71 \\
1 \\
\end{array}$ & ns & $\begin{array}{l}-137 \\
-2 \\
\end{array}$ & $\begin{array}{l}288 \\
5 \\
\end{array}$ & $\begin{array}{l}503 \\
9 \\
\end{array}$ & $* * *$ & $\begin{array}{l}195 \\
3 \\
\end{array}$ & $\begin{array}{l}771 \\
13 \\
\end{array}$ & $\begin{array}{l}30 \\
1\end{array}$ & ns & $\begin{array}{l}-83 \\
-1 \\
\end{array}$ & $\begin{array}{l}147 \\
3 \\
\end{array}$ \\
\hline Comp & Publ. Serv. & $\begin{array}{l}\text { (yuan) } \\
(\%)\end{array}$ & $\begin{array}{l}992 \\
17 \\
\end{array}$ & $* * *$ & $\begin{array}{l}859 \\
-\quad \\
\end{array}$ & $\begin{array}{l}1,107 \\
- \\
\end{array}$ & $\begin{array}{l}358 \\
6 \\
\end{array}$ & $* * *$ & $\begin{array}{l}152 \\
3 \\
\end{array}$ & $\begin{array}{l}605 \\
10 \\
\end{array}$ & $\begin{array}{l}722 \\
12 \\
\end{array}$ & $* * *$ & $\begin{array}{l}443 \\
8 \\
\end{array}$ & $\begin{array}{l}935 \\
16 \\
\end{array}$ & $\begin{array}{l}-88 \\
-2 \\
\end{array}$ & $* * *$ & $\begin{array}{l}-170 \\
-3\end{array}$ & $\begin{array}{l}-6 \\
0\end{array}$ \\
\hline Comp & Govt & $\begin{array}{l}\text { (yuan) } \\
(\%)\end{array}$ & $\begin{array}{l}595 \\
10 \\
\end{array}$ & $* * *$ & $\begin{array}{l}459 \\
-\quad \\
\end{array}$ & $\begin{array}{l}695 \\
-\quad \\
\end{array}$ & $\begin{array}{l}281 \\
5 \\
\end{array}$ & $* * *$ & $\begin{array}{l}61 \\
1 \\
\end{array}$ & $\begin{array}{l}432 \\
7 \\
\end{array}$ & $\begin{array}{l}438 \\
8 \\
\end{array}$ & $* * *$ & $\begin{array}{l}268 \\
5 \\
\end{array}$ & $\begin{array}{l}681 \\
12 \\
\end{array}$ & $\begin{array}{l}-124 \\
-2 \\
\end{array}$ & $* * *$ & $\begin{array}{l}-198 \\
-3 \\
\end{array}$ & $\begin{array}{l}-58 \\
-1 \\
\end{array}$ \\
\hline Olig & Publ. Serv. & $\begin{array}{l}\text { (yuan) } \\
(\%)\end{array}$ & $\begin{array}{l}387 \\
6 \\
\end{array}$ & $* * *$ & $\begin{array}{l}103 \\
-\quad \\
\end{array}$ & $\begin{array}{l}662 \\
-\quad \\
\end{array}$ & $\begin{array}{l}545 \\
9 \\
\end{array}$ & $* * *$ & $\begin{array}{l}217 \\
3 \\
\end{array}$ & $\begin{array}{l}1,005 \\
16 \\
\end{array}$ & & ns & $\begin{array}{l}-519 \\
-8 \\
\end{array}$ & $\begin{array}{l}399 \\
6 \\
\end{array}$ & $\begin{array}{l}-150 \\
-2 \\
\end{array}$ & $* *$ & $\begin{array}{l}-285 \\
-4 \\
\end{array}$ & $\begin{array}{l}5 \\
0 \\
\end{array}$ \\
\hline Olig & Govt & $\begin{array}{l}\text { (yuan) } \\
(\%)\end{array}$ & $\begin{array}{l}-9 \\
0 \\
\end{array}$ & ns & $\begin{array}{l}-287 \\
- \\
\end{array}$ & $\begin{array}{l}258 \\
-\quad \\
\end{array}$ & $\begin{array}{l}470 \\
7 \\
\end{array}$ & $* *$ & $\begin{array}{l}-53 \\
-1 \\
\end{array}$ & $\begin{array}{l}1,041 \\
16 \\
\end{array}$ & $\begin{array}{l}-348 \\
-5 \\
\end{array}$ & ns & $\begin{array}{l}-1,080 \\
-17 \\
\end{array}$ & $\begin{array}{l}243 \\
4 \\
\end{array}$ & $\begin{array}{l}-131 \\
-2 \\
\end{array}$ & $* *$ & $\begin{array}{l}-276 \\
-4 \\
\end{array}$ & $\begin{array}{l}31 \\
1 \\
\end{array}$ \\
\hline Publ. Serv. & Govt & $\begin{array}{l}\text { (yuan) } \\
(\%)\end{array}$ & $\begin{array}{l}-396 \\
-6\end{array}$ & $* * *$ & $\begin{array}{l}-556 \\
-\end{array}$ & $\begin{array}{l}-247 \\
-\end{array}$ & $\begin{array}{l}-40 \\
-1\end{array}$ & & $\begin{array}{l}-189 \\
-3\end{array}$ & $\begin{array}{l}120 \\
2\end{array}$ & $\begin{array}{l}-361 \\
-6\end{array}$ & $* * *$ & $\begin{array}{l}-546 \\
-9\end{array}$ & $\begin{array}{l}-191 \\
-3\end{array}$ & $\begin{array}{l}4 \\
0\end{array}$ & ns & $\begin{array}{l}-89 \\
-1\end{array}$ & $\begin{array}{l}101 \\
2\end{array}$ \\
\hline
\end{tabular}




\begin{tabular}{|c|c|c|c|c|c|c|c|c|c|c|c|c|c|c|c|c|c|c|}
\hline \multirow{2}{*}{$\frac{\frac{2002}{(\mathrm{~A})}}{\text { Comp }}$} & (B) & & \multicolumn{4}{|c|}{ Observed differences } & \multicolumn{4}{|c|}{ Endowment effect } & \multicolumn{4}{|c|}{ Segmentation effect } & \multicolumn{4}{|c|}{ Hours worked effect } \\
\hline & Olig & $\begin{array}{l}\text { (yuan) } \\
(\%)\end{array}$ & $\begin{array}{l}4,227 \\
48\end{array}$ & $* * *$ & $\begin{array}{l}3,796 \\
-\end{array}$ & $\begin{array}{l}4,771 \\
-\end{array}$ & $\begin{array}{l}-125 \\
-1\end{array}$ & ns & $\begin{array}{l}-916 \\
-10\end{array}$ & $\begin{array}{l}444 \\
5\end{array}$ & $\begin{array}{l}5,241 \\
59\end{array}$ & $* * *$ & $\begin{array}{l}4,699 \\
53\end{array}$ & $\begin{array}{l}5,829 \\
66\end{array}$ & $\begin{array}{l}-890 \\
-10\end{array}$ & $* * *$ & $\begin{array}{l}-1,408 \\
-16\end{array}$ & $\begin{array}{l}-506 \\
-6\end{array}$ \\
\hline Comp & Publ. Serv. & $\begin{array}{l}\text { (yuan) } \\
(\%)\end{array}$ & $\begin{array}{l}5,550 \\
63 \\
\end{array}$ & $* * *$ & $\begin{array}{l}, 138 \\
- \\
\end{array}$ & $\begin{array}{l}5,868 \\
-\quad \\
\end{array}$ & $\begin{array}{l}615 \\
7 \\
\end{array}$ & $* * *$ & $\begin{array}{l}195 \\
2 \\
\end{array}$ & $\begin{array}{l}1,058 \\
12 \\
\end{array}$ & $\begin{array}{l}5,628 \\
64 \\
\end{array}$ & $* * *$ & $\begin{array}{l}5,343 \\
60 \\
\end{array}$ & $\begin{array}{l}5,829 \\
66 \\
\end{array}$ & $\begin{array}{l}-693 \\
-8 \\
\end{array}$ & $* * *$ & $\begin{array}{l}-1,111 \\
-13 \\
\end{array}$ & $\begin{array}{l}-371 \\
-4 \\
\end{array}$ \\
\hline Comp & Govt & $\begin{array}{l}\text { (yuan) } \\
(\%)\end{array}$ & $\begin{array}{l}4,385 \\
50 \\
\end{array}$ & $* * *$ & $\begin{array}{l}4,017 \\
- \\
\end{array}$ & $\begin{array}{l}4,735 \\
-\quad \\
\end{array}$ & $\begin{array}{l}884 \\
10 \\
\end{array}$ & $* * *$ & $\begin{array}{l}120 \\
1 \\
\end{array}$ & $\begin{array}{l}1,467 \\
17 \\
\end{array}$ & $\begin{array}{l}4,411 \\
50 \\
\end{array}$ & $* * *$ & $\begin{array}{l}3,883 \\
44 \\
\end{array}$ & $\begin{array}{l}5,002 \\
57 \\
\end{array}$ & $\begin{array}{l}-910 \\
-10 \\
\end{array}$ & $* * *$ & $\begin{array}{l}-1,436 \\
-16 \\
\end{array}$ & $\begin{array}{l}-509 \\
-6 \\
\end{array}$ \\
\hline Olig & Publ. Serv. & $\begin{array}{l}\text { (yuan) } \\
(\%) \\
\end{array}$ & $\begin{array}{l}1,323 \\
10 \\
\end{array}$ & $* * *$ & $\begin{array}{l}725 \\
-\quad \\
\end{array}$ & $\begin{array}{l}1,839 \\
-\quad \\
\end{array}$ & $\begin{array}{l}592 \\
5 \\
\end{array}$ & $* *$ & $\begin{array}{l}-70 \\
-1 \\
\end{array}$ & $\begin{array}{l}1,166 \\
9\end{array}$ & $\begin{array}{l}645 \\
5 \\
\end{array}$ & $* *$ & $\begin{array}{l}-70 \\
-1 \\
\end{array}$ & $\begin{array}{l}1,389 \\
11 \\
\end{array}$ & $\begin{array}{l}86 \\
1 \\
\end{array}$ & ns & $\begin{array}{l}-178 \\
-1 \\
\end{array}$ & $\begin{array}{l}351 \\
3 \\
\end{array}$ \\
\hline Olig & Govt & $\begin{array}{l}\text { (yuan) } \\
(\%)\end{array}$ & $\begin{array}{l}159 \\
1 \\
\end{array}$ & ns & $\begin{array}{l}-313 \\
- \\
\end{array}$ & $\begin{array}{l}668 \\
- \\
\end{array}$ & $\begin{array}{l}1,155 \\
9 \\
\end{array}$ & $* * *$ & $\begin{array}{l}456 \\
3 \\
\end{array}$ & $\begin{array}{l}1,926 \\
15 \\
\end{array}$ & $\begin{array}{l}-891 \\
-7 \\
\end{array}$ & $* * *$ & $\begin{array}{l}-1,775 \\
-14 \\
\end{array}$ & $\begin{array}{l}-19 \\
0 \\
\end{array}$ & $\begin{array}{l}-105 \\
-1 \\
\end{array}$ & ns & $\begin{array}{l}-347 \\
-3 \\
\end{array}$ & $\begin{array}{l}155 \\
1 \\
\end{array}$ \\
\hline Publ. Serv. & Govt & $\begin{array}{l}\text { (yuan) } \\
(\%)\end{array}$ & $\begin{array}{l}-1,165 \\
-9\end{array}$ & $* * *$ & $\begin{array}{l}-1,608 \\
-\end{array}$ & $\begin{array}{l}-750 \\
-\end{array}$ & $\begin{array}{l}766 \\
6\end{array}$ & $* * *$ & $\begin{array}{l}139 \\
1\end{array}$ & $\begin{array}{l}1,428 \\
11\end{array}$ & $\begin{array}{l}-1,684 \\
-13\end{array}$ & $* * *$ & $\begin{array}{l}-2,108 \\
-16\end{array}$ & $\begin{array}{l}-1,172 \\
-9\end{array}$ & $\begin{array}{l}-246 \\
-2\end{array}$ & $* * *$ & $\begin{array}{l}-483 \\
-4\end{array}$ & $\begin{array}{l}-7 \\
0\end{array}$ \\
\hline
\end{tabular}

Source: Authors' calculations using the 1995 and 2002 CHIP survey data.

Notes: See Table 10 and text for a full definition of sectors. 
Table 12 - Decomposition of observed earnings gaps by regions

\begin{tabular}{|c|c|c|c|c|c|c|c|c|c|c|c|c|c|c|c|c|c|c|}
\hline \multirow{2}{*}{$\frac{\frac{1995}{(\mathrm{~A})}}{\text { Coast }}$} & \multicolumn{2}{|l|}{ (B) } & \multicolumn{4}{|c|}{ Observed differences } & \multicolumn{4}{|c|}{ Endowment effect } & \multicolumn{4}{|c|}{ Segmentation effect } & \multicolumn{3}{|c|}{ Hours worked effect } & $95 \%$ \\
\hline & Centre & $\begin{array}{l}\text { (yuan) } \\
(\%)\end{array}$ & $\begin{array}{l}-2,149 \\
-40\end{array}$ & $* * *$ & $\begin{array}{l}-2,293 \\
- \\
\end{array}$ & $\begin{array}{l}-1,984 \\
- \\
\end{array}$ & $\begin{array}{l}-215 \\
-4\end{array}$ & $* * *$ & $\begin{array}{l}-312 \\
-6\end{array}$ & $\begin{array}{l}-117 \\
-2\end{array}$ & $\begin{array}{l}-1,908 \\
-35 \\
\end{array}$ & $* * *$ & $\begin{array}{l}-2,047 \\
-38 \\
\end{array}$ & $\begin{array}{l}-1,764 \\
-32 \\
\end{array}$ & $\begin{array}{l}-27 \\
-1\end{array}$ & ns & $\begin{array}{l}-81 \\
-2\end{array}$ & $\begin{array}{l}27 \\
1\end{array}$ \\
\hline Coast & West & $\begin{array}{l}\text { (yuan) } \\
(\%)\end{array}$ & $\begin{array}{l}-1,707 \\
-29 \\
\end{array}$ & $* * *$ & $\begin{array}{l}-1,861 \\
- \\
\end{array}$ & $\begin{array}{l}-1,547 \\
- \\
\end{array}$ & $\begin{array}{l}-104 \\
-2 \\
\end{array}$ & $* *$ & $\begin{array}{l}-239 \\
-4 \\
\end{array}$ & $\begin{array}{l}21 \\
0\end{array}$ & $\begin{array}{l}-1,664 \\
-28 \\
\end{array}$ & $* * *$ & $\begin{array}{l}-1,853 \\
-32 \\
\end{array}$ & $\begin{array}{l}-1,472 \\
-25 \\
\end{array}$ & $\begin{array}{l}61 \\
1 \\
\end{array}$ & $* *$ & $\begin{array}{l}-6 \\
0 \\
\end{array}$ & $\begin{array}{l}122 \\
2 \\
\end{array}$ \\
\hline Coast & Municip & $\begin{array}{l}\text { (yuan) } \\
(\%)\end{array}$ & $\begin{array}{l}-63 \\
-1 \\
\end{array}$ & ns & $\begin{array}{l}-287 \\
- \\
\end{array}$ & $\begin{array}{l}176 \\
-\quad \\
\end{array}$ & $\begin{array}{l}640 \\
9 \\
\end{array}$ & $* * *$ & $\begin{array}{l}71 \\
1 \\
\end{array}$ & $\begin{array}{l}1,290 \\
17 \\
\end{array}$ & $\begin{array}{l}-844 \\
-11 \\
\end{array}$ & $* * *$ & $\begin{array}{l}-1,492 \\
-20 \\
\end{array}$ & $\begin{array}{l}-175 \\
-2 \\
\end{array}$ & $\begin{array}{l}141 \\
2 \\
\end{array}$ & ns & $\begin{array}{l}-95 \\
-1 \\
\end{array}$ & $\begin{array}{l}379 \\
5 \\
\end{array}$ \\
\hline Coast & N-E. & $\begin{array}{l}\text { (yuan) } \\
(\%) \\
\end{array}$ & $\begin{array}{l}-1,746 \\
-30 \\
\end{array}$ & $* * *$ & $\begin{array}{l}-1,975 \\
- \\
\end{array}$ & $\begin{array}{l}-1,545 \\
- \\
\end{array}$ & $\begin{array}{l}519 \\
9 \\
\end{array}$ & $* * *$ & $\begin{array}{l}134 \\
2 \\
\end{array}$ & $\begin{array}{l}870 \\
15 \\
\end{array}$ & $\begin{array}{l}-2,337 \\
-40 \\
\end{array}$ & $* * *$ & $\begin{array}{l}-2,838 \\
-50 \\
\end{array}$ & $\begin{array}{l}-1,936 \\
-33 \\
\end{array}$ & $\begin{array}{l}72 \\
1 \\
\end{array}$ & $*$ & $\begin{array}{l}-19 \\
0 \\
\end{array}$ & $\begin{array}{l}195 \\
3 \\
\end{array}$ \\
\hline Centre & West & $\begin{array}{l}\text { (yuan) } \\
(\%) \\
\end{array}$ & $\begin{array}{l}442 \\
8 \\
\end{array}$ & $* * *$ & $\begin{array}{l}355 \\
-\quad \\
\end{array}$ & $\begin{array}{l}529 \\
-\quad \\
\end{array}$ & $\begin{array}{l}131 \\
2 \\
\end{array}$ & $* * *$ & $\begin{array}{l}52 \\
1 \\
\end{array}$ & $\begin{array}{l}225 \\
4 \\
\end{array}$ & $\begin{array}{l}251 \\
5 \\
\end{array}$ & $* * *$ & $\begin{array}{l}156 \\
3 \\
\end{array}$ & $\begin{array}{l}347 \\
6 \\
\end{array}$ & $\begin{array}{l}60 \\
1 \\
\end{array}$ & $* * *$ & $\begin{array}{l}13 \\
0 \\
\end{array}$ & $\begin{array}{l}104 \\
2 \\
\end{array}$ \\
\hline Centre & Municip & $\begin{array}{l}\text { (yuan) } \\
(\%)\end{array}$ & $\begin{array}{l}2,086 \\
39 \\
\end{array}$ & $* * *$ & $\begin{array}{l}1,857 \\
- \\
\end{array}$ & $\begin{array}{l}, 263 \\
- \\
\end{array}$ & $\begin{array}{l}790 \\
15 \\
\end{array}$ & $* * *$ & $\begin{array}{l}383 \\
7 \\
\end{array}$ & $\begin{array}{l}1,182 \\
22 \\
\end{array}$ & $\begin{array}{l}1,199 \\
22 \\
\end{array}$ & $* * *$ & $\begin{array}{l}756 \\
14 \\
\end{array}$ & $\begin{array}{l}1,668 \\
31 \\
\end{array}$ & $\begin{array}{l}97 \\
2 \\
\end{array}$ & * & $\begin{array}{l}-29 \\
-1 \\
\end{array}$ & $\begin{array}{l}233 \\
4 \\
\end{array}$ \\
\hline Centre & N-E. & $\begin{array}{l}\text { (yuan) } \\
(\%) \\
\end{array}$ & $\begin{array}{l}403 \\
7 \\
\end{array}$ & $* * *$ & $\begin{array}{l}238 \\
-\quad \\
\end{array}$ & $\begin{array}{l}563 \\
-\quad \\
\end{array}$ & $\begin{array}{l}723 \\
13 \\
\end{array}$ & $* * *$ & $\begin{array}{l}317 \\
6 \\
\end{array}$ & $\begin{array}{l}1,121 \\
21\end{array}$ & $\begin{array}{l}-382 \\
-7 \\
\end{array}$ & * & $\begin{array}{l}-832 \\
-15 \\
\end{array}$ & $\begin{array}{l}93 \\
2 \\
\end{array}$ & $\begin{array}{l}62 \\
1 \\
\end{array}$ & * & $\begin{array}{l}-36 \\
-1 \\
\end{array}$ & $\begin{array}{l}174 \\
3 \\
\end{array}$ \\
\hline West & Municip & $\begin{array}{l}\text { (yuan) } \\
(\%)\end{array}$ & $\begin{array}{l}1,644 \\
28 \\
\end{array}$ & $* * *$ & $\begin{array}{l}1,429 \\
- \\
\end{array}$ & $\begin{array}{l}1,840 \\
- \\
\end{array}$ & $\begin{array}{l}791 \\
14 \\
\end{array}$ & $* * *$ & $\begin{array}{l}373 \\
6 \\
\end{array}$ & $\begin{array}{l}1,204 \\
21 \\
\end{array}$ & $\begin{array}{l}814 \\
14 \\
\end{array}$ & $* * *$ & $\begin{array}{l}347 \\
6 \\
\end{array}$ & $\begin{array}{l}1,316 \\
22 \\
\end{array}$ & $\begin{array}{l}39 \\
1 \\
\end{array}$ & ns & $\begin{array}{l}-63 \\
-1 \\
\end{array}$ & $\begin{array}{l}158 \\
3 \\
\end{array}$ \\
\hline West & N-E. & $\begin{array}{l}\text { (yuan) } \\
(\%)\end{array}$ & $\begin{array}{l}-39 \\
-1 \\
\end{array}$ & ns & $\begin{array}{l}-185 \\
- \\
\end{array}$ & $\begin{array}{l}124 \\
-\quad \\
\end{array}$ & $\begin{array}{l}633 \\
11 \\
\end{array}$ & $* * *$ & $\begin{array}{l}360 \\
6 \\
\end{array}$ & $\begin{array}{l}923 \\
16 \\
\end{array}$ & $\begin{array}{l}-663 \\
-11 \\
\end{array}$ & $* * *$ & $\begin{array}{l}-986 \\
-17 \\
\end{array}$ & $\begin{array}{l}-343 \\
-6 \\
\end{array}$ & $\begin{array}{l}-9 \\
0 \\
\end{array}$ & ns & $\begin{array}{l}-105 \\
-2 \\
\end{array}$ & $\begin{array}{l}95 \\
2 \\
\end{array}$ \\
\hline Municip & N-E. & $\begin{array}{l}\text { (yuan) } \\
\text { (\%) }\end{array}$ & $\begin{array}{l}-1,683 \\
-29\end{array}$ & $* * *$ & $\begin{array}{l}-1,914 \\
-\end{array}$ & $\begin{array}{l}-1,419 \\
-\end{array}$ & $\begin{array}{l}-585 \\
-10\end{array}$ & $* * *$ & $\begin{array}{l}-1,018 \\
-17\end{array}$ & $\begin{array}{l}-156 \\
-3\end{array}$ & $\begin{array}{l}-994 \\
-17\end{array}$ & $* * *$ & $\begin{array}{l}-1,495 \\
-26\end{array}$ & $\begin{array}{l}-509 \\
-9\end{array}$ & $\begin{array}{l}-105 \\
-2\end{array}$ & * & $\begin{array}{l}-262 \\
-4\end{array}$ & $\begin{array}{l}36 \\
1\end{array}$ \\
\hline
\end{tabular}




\begin{tabular}{|c|c|c|c|c|c|c|c|c|c|c|c|c|c|c|c|c|c|c|}
\hline \multirow{2}{*}{$\frac{\frac{2002}{(A)}}{\frac{\text { Coast }}{2}}$} & \multicolumn{2}{|l|}{ (B) } & \multicolumn{4}{|c|}{ Observed differences } & \multicolumn{4}{|c|}{ Endowment effect } & \multicolumn{4}{|c|}{ Segmentation effect } & \multicolumn{3}{|c|}{ Hours worked effect } & $95 \%$ \\
\hline & Centre & $\begin{array}{l}\text { (yuan) } \\
(\%)\end{array}$ & $\begin{array}{l}-3,594 \\
-37 \\
\end{array}$ & $* * *$ & $\begin{array}{l}-3,903 \\
- \\
\end{array}$ & $\begin{array}{l}-3,153 \\
- \\
\end{array}$ & $\begin{array}{l}142 \\
2 \\
\end{array}$ & ns & $\begin{array}{l}-255 \\
-3 \\
\end{array}$ & $\begin{array}{l}509 \\
5 \\
\end{array}$ & $\begin{array}{l}-3,967 \\
-41 \\
\end{array}$ & $* * *$ & $\begin{array}{l}-4,156 \\
-43 \\
\end{array}$ & $\begin{array}{l}-3,654 \\
-38 \\
\end{array}$ & $\begin{array}{l}231 \\
2 \\
\end{array}$ & $* * *$ & $\begin{array}{l}85 \\
1 \\
\end{array}$ & $\begin{array}{l}424 \\
4 \\
\end{array}$ \\
\hline Coast & West & $\begin{array}{l}\text { (yuan) } \\
(\%)\end{array}$ & $\begin{array}{l}-2,941 \\
-28 \\
\end{array}$ & $* * *$ & $\begin{array}{l}-3,453 \\
- \\
\end{array}$ & $\begin{array}{l}-2,554 \\
- \\
\end{array}$ & $\begin{array}{l}-202 \\
-2 \\
\end{array}$ & ns & $\begin{array}{l}-591 \\
-6 \\
\end{array}$ & $\begin{array}{l}231 \\
2 \\
\end{array}$ & $\begin{array}{l}-2,879 \\
-28 \\
\end{array}$ & $* * *$ & $\begin{array}{l}-3,413 \\
-33 \\
\end{array}$ & $\begin{array}{l}-2,337 \\
-22 \\
\end{array}$ & $\begin{array}{l}141 \\
1 \\
\end{array}$ & $* *$ & $\begin{array}{l}-2 \\
0\end{array}$ & $\begin{array}{l}288 \\
3 \\
\end{array}$ \\
\hline Coast & Municip & $\begin{array}{l}\text { (yuan) } \\
(\%)\end{array}$ & $\begin{array}{l}-685 \\
-5 \\
\end{array}$ & $* * *$ & $\begin{array}{l}-1,248 \\
- \\
\end{array}$ & $\begin{array}{l}-177 \\
- \\
\end{array}$ & $\begin{array}{l}1,808 \\
14 \\
\end{array}$ & ** & $\begin{array}{l}-61 \\
-1 \\
\end{array}$ & $\begin{array}{l}4,305 \\
34\end{array}$ & $\begin{array}{l}-2,312 \\
-18\end{array}$ & $* * *$ & $\begin{array}{l}-4,987 \\
-39\end{array}$ & $\begin{array}{l}-799 \\
-6\end{array}$ & $\begin{array}{l}-181 \\
-1\end{array}$ & ns & $\begin{array}{l}-631 \\
-5\end{array}$ & $\begin{array}{l}193 \\
2\end{array}$ \\
\hline Coast & N-E. & $\begin{array}{l}\text { (yuan) } \\
\text { (\%) }\end{array}$ & $\begin{array}{l}-3,285 \\
-33\end{array}$ & $* * *$ & $\begin{array}{l}-3,720 \\
- \\
\end{array}$ & $\begin{array}{l}-2,879 \\
- \\
\end{array}$ & $\begin{array}{l}731 \\
7\end{array}$ & $* *$ & $\begin{array}{l}-144 \\
-1\end{array}$ & $\begin{array}{l}1,681 \\
17\end{array}$ & $\begin{array}{l}-4,178 \\
-41\end{array}$ & $* * *$ & $\begin{array}{l}-4,559 \\
-46\end{array}$ & $\begin{array}{l}-3,722 \\
-37\end{array}$ & $\begin{array}{l}162 \\
2 \\
\end{array}$ & $*$ & $\begin{array}{l}-124 \\
-1\end{array}$ & $\begin{array}{l}433 \\
4 \\
\end{array}$ \\
\hline Centre & West & $\begin{array}{l}\text { (yuan) } \\
(\%)\end{array}$ & $\begin{array}{l}653 \\
7 \\
\end{array}$ & $* * *$ & $\begin{array}{l}361 \\
-\quad \\
\end{array}$ & $\begin{array}{l}1,006 \\
- \\
\end{array}$ & $\begin{array}{l}-313 \\
-3 \\
\end{array}$ & $* * *$ & $\begin{array}{l}-517 \\
-5 \\
\end{array}$ & $\begin{array}{l}-91 \\
-1 \\
\end{array}$ & $\begin{array}{l}1,050 \\
11 \\
\end{array}$ & $* * *$ & $\begin{array}{l}659 \\
7 \\
\end{array}$ & $\begin{array}{l}1,475 \\
15 \\
\end{array}$ & $\begin{array}{l}-84 \\
-1\end{array}$ & * & $\begin{array}{l}-199 \\
-2\end{array}$ & $\begin{array}{l}36 \\
0\end{array}$ \\
\hline Centre & Municip & $\begin{array}{l}\text { (yuan) } \\
(\%)\end{array}$ & $\begin{array}{l}2,909 \\
30 \\
\end{array}$ & $* * *$ & $\begin{array}{l}2,341 \\
- \\
\end{array}$ & $\begin{array}{l}3,418 \\
- \\
\end{array}$ & $\begin{array}{l}723 \\
7 \\
\end{array}$ & ns & $\begin{array}{l}-791 \\
-8 \\
\end{array}$ & $\begin{array}{l}2,178 \\
22 \\
\end{array}$ & $\begin{array}{l}2,670 \\
27 \\
\end{array}$ & $* * *$ & $\begin{array}{l}1,341 \\
14 \\
\end{array}$ & $\begin{array}{l}4,077 \\
41 \\
\end{array}$ & $\begin{array}{l}-484 \\
-5 \\
\end{array}$ & $* * *$ & $\begin{array}{l}-832 \\
-9 \\
\end{array}$ & $\begin{array}{l}-87 \\
-1 \\
\end{array}$ \\
\hline Centre & N-E. & $\begin{array}{l}\text { (yuan) } \\
(\%) \\
\end{array}$ & $\begin{array}{l}309 \\
3 \\
\end{array}$ & $* *$ & $\begin{array}{l}-46 \\
- \\
\end{array}$ & $\begin{array}{l}670 \\
-\quad \\
\end{array}$ & $\begin{array}{l}173 \\
2 \\
\end{array}$ & ns & $\begin{array}{l}-243 \\
-3 \\
\end{array}$ & $\begin{array}{l}634 \\
7 \\
\end{array}$ & $\begin{array}{l}222 \\
2 \\
\end{array}$ & ns & $\begin{array}{l}-354 \\
-4 \\
\end{array}$ & $\begin{array}{l}832 \\
9 \\
\end{array}$ & $\begin{array}{l}-86 \\
-1 \\
\end{array}$ & ns & $\begin{array}{l}-287 \\
-3 \\
\end{array}$ & $\begin{array}{l}98 \\
1 \\
\end{array}$ \\
\hline West & Municip & $\begin{array}{l}\text { (yuan) } \\
(\%)\end{array}$ & $\begin{array}{l}2,256 \\
22 \\
\end{array}$ & $* * *$ & $\begin{array}{l}1,760 \\
- \\
\end{array}$ & $\begin{array}{l}2,735 \\
- \\
\end{array}$ & $\begin{array}{l}1,362 \\
13 \\
\end{array}$ & $*$ & $\begin{array}{l}-247 \\
-2 \\
\end{array}$ & $\begin{array}{l}2,894 \\
28 \\
\end{array}$ & $\begin{array}{l}1,191 \\
11 \\
\end{array}$ & $*$ & $\begin{array}{l}-528 \\
-5 \\
\end{array}$ & $\begin{array}{l}2,958 \\
28 \\
\end{array}$ & $\begin{array}{l}-298 \\
-3 \\
\end{array}$ & $* * *$ & $\begin{array}{l}-600 \\
-6 \\
\end{array}$ & $\begin{array}{l}-23 \\
0 \\
\end{array}$ \\
\hline West & N-E. & $\begin{array}{l}\text { (yuan) } \\
\text { (\%) }\end{array}$ & $\begin{array}{l}-344 \\
-3\end{array}$ & $* * *$ & $\begin{array}{l}-822 \\
- \\
\end{array}$ & $\begin{array}{l}0 \\
-\end{array}$ & $\begin{array}{l}597 \\
6\end{array}$ & $* * *$ & $\begin{array}{l}211 \\
2\end{array}$ & $\begin{array}{l}1,028 \\
10\end{array}$ & $\begin{array}{l}-995 \\
-10\end{array}$ & $* * *$ & $\begin{array}{l}-1,584 \\
-16\end{array}$ & $\begin{array}{l}-371 \\
-4\end{array}$ & $\begin{array}{l}54 \\
1\end{array}$ & ns & $\begin{array}{l}-183 \\
-2\end{array}$ & $\begin{array}{l}261 \\
3\end{array}$ \\
\hline Municip & N-E. & $\begin{array}{l}\text { (yuan) } \\
\text { (\%) }\end{array}$ & $\begin{array}{l}-2,600 \\
-26\end{array}$ & $* * *$ & $\begin{array}{l}-3,227 \\
-\end{array}$ & $\begin{array}{l}-2,060 \\
-\end{array}$ & $\begin{array}{l}-997 \\
-10\end{array}$ & $* * *$ & $\begin{array}{l}-1,782 \\
-18\end{array}$ & $\begin{array}{l}-180 \\
-2\end{array}$ & $\begin{array}{l}-2,056 \\
-20\end{array}$ & $* * *$ & $\begin{array}{l}-3,100 \\
-31\end{array}$ & $\begin{array}{l}-1,134 \\
-11\end{array}$ & $\begin{array}{l}452 \\
5\end{array}$ & $* * *$ & $\begin{array}{l}184 \\
2\end{array}$ & $\begin{array}{l}721 \\
7\end{array}$ \\
\hline
\end{tabular}

Source: Authors' calculations using the 1995 and 2002 CHIP survey data.

Notes: See Table 10 and text for a full definition of regions. 
Appendix A1 - Hourly wage functions by ownership, Year: 1995

\begin{tabular}{|c|c|c|c|c|c|c|c|c|c|c|}
\hline & \multicolumn{2}{|l|}{ SOES } & \multicolumn{2}{|l|}{$\overline{\text { UCES }}$} & \multicolumn{2}{|l|}{ PIEs } & \multicolumn{2}{|l|}{ FIEs } & \multicolumn{2}{|l|}{ GAIs } \\
\hline & Women & Men & Women & Men & Women & Men & Women & Men & Women & Men \\
\hline \multirow[t]{2}{*}{ Education } & 0.015 & 0.025 & 0.002 & 0.018 & -0.245 & -0.069 & 0.052 & 0.074 & 0.021 & 0.013 \\
\hline & 3.11 & 5.56 & 0.17 & 1.46 & -2.02 & -0.57 & 1.2 & 1.53 & 3.54 & 3.2 \\
\hline \multirow[t]{2}{*}{ Work Exp. } & 0.069 & 0.045 & 0.074 & 0.062 & 0.178 & 0.111 & 0.028 & 0.026 & 0.052 & 0.044 \\
\hline & 10.05 & 11.07 & 5.78 & 6.05 & 2.23 & 1.49 & 1.04 & 1.1 & 8.11 & 9.02 \\
\hline \multirow[t]{2}{*}{$\left(\right.$ Work Exp.) ${ }^{2}$} & -0.00128 & -0.00065 & -0.00172 & -0.00123 & -0.00491 & -0.00332 & 0.00001 & -0.00027 & -0.00086 & -0.00061 \\
\hline & -7.06 & -6.67 & -4.39 & -5.01 & -1.51 & -1.23 & 0.01 & -0.4 & -5.46 & -6.05 \\
\hline \multirow[t]{2}{*}{ Central Province } & -0.055 & -0.023 & 0.024 & -0.025 & 0.523 & -0.173 & 0.593 & 0.338 & -0.127 & -0.066 \\
\hline & -2.17 & -1 & 0.53 & -0.41 & 0.76 & -0.31 & 1.97 & 1.32 & -4.56 & -3.21 \\
\hline \multirow[t]{2}{*}{ Coastal Province } & 0.153 & 0.216 & 0.312 & 0.275 & 2.351 & 0.409 & 0.758 & 0.527 & 0.205 & 0.226 \\
\hline & 4.92 & 8.64 & 6.41 & 4.93 & 4.16 & 0.77 & 2.72 & 2.2 & 6.07 & 7.73 \\
\hline \multirow[t]{2}{*}{ Big city } & 0.130 & 0.135 & 0.156 & 0.116 & 1.716 & 0.841 & 0.364 & -0.086 & 0.010 & 0.057 \\
\hline & 6.08 & 6.95 & 4.06 & 2.34 & 3.14 & 3.11 & 2.27 & -0.56 & 0.37 & 2.57 \\
\hline \multirow[t]{2}{*}{ Communist } & 0.147 & 0.076 & 0.080 & 0.178 & -0.361 & 0.924 & -0.089 & -0.061 & 0.003 & -0.014 \\
\hline & 5 & 3.6 & 1.16 & 2.42 & -0.46 & 2.73 & -0.37 & -0.29 & 0.09 & -0.66 \\
\hline \multirow[t]{2}{*}{ Vocational School } & -0.057 & -0.016 & -0.128 & -0.104 & -0.634 & -0.340 & 0.064 & -0.139 & -0.176 & -0.107 \\
\hline & -2.07 & -0.59 & -2.52 & -1.62 & -1.01 & -0.68 & 0.29 & -0.56 & -3.64 & -2.75 \\
\hline \multirow[t]{2}{*}{ Change in hukou } & -0.065 & 0.043 & -0.074 & 0.013 & -1.802 & -0.946 & 0.050 & 0.089 & -0.087 & 0.032 \\
\hline & -1.67 & 1.48 & -1.25 & 0.17 & -2.7 & -1.6 & 0.28 & 0.45 & -2.34 & 1.54 \\
\hline \multirow[t]{2}{*}{ Constant term } & -0.138 & -0.025 & -0.139 & -0.134 & 0.137 & 0.083 & -0.756 & -0.343 & 0.168 & 0.288 \\
\hline & -1.54 & -0.35 & -0.92 & -0.72 & 0.09 & 0.05 & -1.62 & -0.51 & 1.65 & 3.74 \\
\hline \# obs. & 2551 & 3224 & 908 & 626 & 40 & 44 & 63 & 75 & 1445 & 1754 \\
\hline $\mathbf{R}^{2}$ & 0.21 & 0.20 & 0.19 & 0.19 & 0.53 & 0.35 & 0.35 & 0.21 & 0.25 & 0.26 \\
\hline
\end{tabular}

Note: T-statistics in italics. 
Appendix A2 - Hourly wage functions by ownership, Year: 2002

\begin{tabular}{|c|c|c|c|c|c|c|c|c|c|c|}
\hline & \multicolumn{2}{|l|}{ SOES } & \multicolumn{2}{|l|}{ UCEs } & \multicolumn{2}{|l|}{ PIEs } & \multicolumn{2}{|l|}{ FIEs } & \multicolumn{2}{|l|}{ GAIs } \\
\hline & Women & Men & Women & Men & Women & Men & Women & Men & Women & Men \\
\hline \multirow[t]{2}{*}{ Education } & 0.041 & 0.044 & 0.034 & 0.018 & 0.117 & 0.096 & 0.052 & 0.103 & 0.068 & 0.048 \\
\hline & 4.95 & 7.26 & 2 & 0.98 & 5.06 & 6.35 & 2.29 & 4.24 & 10.71 & 9.33 \\
\hline \multirow[t]{2}{*}{ Work Exp. } & 0.061 & 0.045 & 0.040 & 0.048 & 0.019 & 0.048 & 0.051 & 0.043 & 0.050 & 0.037 \\
\hline & 5.82 & 7.43 & 2.52 & 2.91 & 1.11 & 3.27 & 1.76 & 2.12 & 6.48 & 6.65 \\
\hline \multirow[t]{2}{*}{ (Work Exp.) ${ }^{2}$} & -0.0013 & -0.0009 & -0.0008 & -0.0009 & 0.0000 & -0.0006 & -0.0013 & -0.0004 & -0.0009 & -0.0005 \\
\hline & -4.69 & -5.97 & -1.98 & -2.63 & 0.08 & -1.63 & -1.51 & -0.87 & -4.33 & -4.13 \\
\hline \multirow[t]{2}{*}{ Central Province } & -0.112 & -0.014 & -0.192 & 0.061 & -0.212 & -0.151 & 0.476 & 0.263 & -0.198 & -0.102 \\
\hline & -2.68 & -0.46 & -2.33 & 0.68 & -2.11 & -1.47 & 2.17 & 1.79 & -5.44 & -3.46 \\
\hline \multirow[t]{2}{*}{ Coastal Province } & 0.105 & 0.174 & 0.088 & 0.191 & 0.311 & 0.447 & 0.558 & 0.272 & 0.178 & 0.167 \\
\hline & 2.15 & 4.93 & 0.96 & 1.83 & 3.27 & 4.73 & 2.43 & 2.08 & 4.19 & 4.6 \\
\hline \multirow[t]{2}{*}{ Big city } & 0.176 & 0.109 & 0.132 & 0.278 & 0.297 & 0.374 & 0.174 & 0.210 & -0.033 & 0.126 \\
\hline & 4.96 & 4.12 & 1.98 & 3.87 & 3.65 & 4.65 & 1.12 & 1.63 & -0.97 & 4.47 \\
\hline \multirow[t]{2}{*}{ Communist } & 0.135 & 0.136 & 0.253 & 0.164 & 0.387 & 0.279 & 0.523 & -0.138 & 0.052 & 0.116 \\
\hline & 3.08 & 4.54 & 2.73 & 2.06 & 3.25 & 3.16 & 2.65 & -0.71 & 1.37 & 4.06 \\
\hline \multirow[t]{2}{*}{ Vocational School } & 0.094 & 0.052 & 0.133 & 0.135 & -0.065 & 0.162 & 0.151 & -0.135 & 0.021 & 0.004 \\
\hline & 1.84 & 1.55 & 1.22 & 1.11 & -0.55 & 1.68 & 0.8 & -0.87 & 0.59 & 0.14 \\
\hline \multirow[t]{2}{*}{ Change in hukou } & -0.166 & -0.077 & -0.096 & 0.158 & -0.190 & 0.058 & 0.254 & 0.039 & 0.043 & 0.065 \\
\hline & -2.72 & -1.74 & -0.91 & 1.74 & -1.35 & 0.39 & 0.84 & 0.24 & 0.85 & 2.14 \\
\hline \multirow[t]{2}{*}{ Constant term } & 0.203 & 0.394 & 0.246 & 0.198 & -0.956 & -1.071 & -0.299 & -0.399 & 0.247 & 0.539 \\
\hline & 1.69 & 3.99 & 1.14 & 0.73 & -3.31 & -5.02 & -0.77 & -1.16 & 2.24 & 5.55 \\
\hline \# obs. & 1315 & 2056 & 383 & 295 & 781 & 986 & 86 & 125 & 1368 & 1686 \\
\hline $\mathbf{R}^{2}$ & 0.15 & 0.13 & 0.12 & 0.12 & 0.17 & 0.16 & 0.18 & 0.23 & 0.19 & 0.18 \\
\hline
\end{tabular}

Note: T-statistics in italics. 
Appendix A3 - Hourly wage functions by economic sector, Year: 1995

\begin{tabular}{|c|c|c|c|c|c|c|c|c|}
\hline & \multicolumn{2}{|c|}{$\overline{\text { Competitive }}$} & \multicolumn{2}{|c|}{ Oligopolistic } & \multicolumn{2}{|c|}{ Public Services } & \multicolumn{2}{|c|}{ Government } \\
\hline & Women & Men & Women & Men & Women & Men & Women & Men \\
\hline \multirow[t]{2}{*}{ Education } & 0.017 & 0.023 & 0.043 & 0.056 & 0.026 & 0.021 & 0.019 & 0.011 \\
\hline & 3.62 & 5.12 & 2.22 & 3.35 & 4.04 & 3.1 & 1.65 & 2.07 \\
\hline \multirow[t]{2}{*}{ Work Exp. } & 0.058 & 0.045 & 0.064 & 0.059 & 0.052 & 0.059 & 0.044 & 0.032 \\
\hline & 9.33 & 11.3 & 4.03 & 5.01 & 6.74 & 6.06 & 3.51 & 4.41 \\
\hline \multirow[t]{2}{*}{ (Work Exp.) ${ }^{2}$} & -0.0011 & -0.0007 & -0.0013 & -0.0010 & -0.0008 & -0.0009 & -0.0006 & -0.0004 \\
\hline & -6.2 & -7.22 & -2.65 & -3.46 & -4.51 & -3.86 & -2.09 & -2.68 \\
\hline \multirow[t]{2}{*}{ Central Province } & -0.035 & -0.046 & -0.080 & -0.058 & -0.104 & -0.002 & -0.102 & -0.081 \\
\hline & -1.39 & -2.01 & -0.76 & -0.77 & -3.03 & -0.07 & -1.99 & -2.81 \\
\hline \multirow[t]{2}{*}{ Coastal Province } & 0.211 & 0.208 & 0.322 & 0.239 & 0.190 & 0.231 & 0.262 & 0.242 \\
\hline & 7.45 & 8.46 & 2.82 & 2.62 & 4.8 & 5.77 & 3.83 & 5.25 \\
\hline \multirow[t]{2}{*}{ Big city } & 0.159 & 0.159 & 0.136 & -0.064 & 0.049 & 0.079 & -0.099 & 0.078 \\
\hline & 7.9 & 8.19 & 1.63 & -0.8 & 1.62 & 2.41 & -1.81 & 2.29 \\
\hline \multirow[t]{2}{*}{ Communist } & 0.145 & 0.091 & 0.188 & 0.031 & -0.002 & 0.003 & 0.073 & 0.023 \\
\hline & 4.89 & 4.19 & 1.79 & 0.4 & -0.06 & 0.08 & 1.41 & 0.72 \\
\hline \multirow[t]{2}{*}{ Vocational School } & -0.065 & -0.055 & -0.260 & -0.088 & -0.120 & -0.195 & -0.222 & -0.025 \\
\hline & -2.45 & -2.03 & -2.15 & -0.84 & -2.03 & -2.88 & -2.25 & -0.51 \\
\hline \multirow[t]{2}{*}{ Change in hukou } & -0.065 & 0.034 & -0.204 & 0.030 & -0.006 & 0.057 & -0.228 & -0.029 \\
\hline & -1.64 & 1.17 & -1.48 & 0.31 & -0.13 & 1.54 & -3.69 & -1.01 \\
\hline \multirow[t]{2}{*}{ Constant term } & -0.115 & -0.002 & -0.281 & -0.292 & 0.052 & 0.014 & 0.215 & 0.402 \\
\hline & -1.4 & -0.03 & -0.99 & -1.2 & 0.47 & 0.11 & 1.06 & 3.69 \\
\hline \# obs. & 3019 & 3324 & 312 & 295 & 791 & 675 & 477 & 772 \\
\hline $\mathbf{R}^{2}$ & 0.18 & 0.19 & 0.28 & 0.25 & 0.28 & 0.33 & 0.29 & 0.24 \\
\hline
\end{tabular}

Note: T-statistics in italics. 
Appendix A4 - Hourly wage functions by economic sector, Year: 2002

\begin{tabular}{|c|c|c|c|c|c|c|c|c|}
\hline & \multicolumn{2}{|c|}{ Competitive } & \multicolumn{2}{|c|}{ Oligopolistic } & \multicolumn{2}{|c|}{ Public Services } & \multicolumn{2}{|c|}{ Government } \\
\hline & Women & Men & Women & Men & Women & Men & Women & Men \\
\hline \multirow[t]{2}{*}{ Education } & 0.071 & 0.071 & 0.043 & 0.036 & 0.068 & 0.058 & 0.054 & 0.031 \\
\hline & 7.42 & 9.82 & 2.12 & 2.56 & 7.32 & 6.63 & 3.81 & 3.94 \\
\hline \multirow[t]{2}{*}{ Work Exp. } & 0.056 & 0.049 & 0.098 & 0.042 & 0.046 & 0.042 & 0.065 & 0.036 \\
\hline & 6.66 & 6.81 & 4.93 & 3.1 & 4.34 & 4.48 & 4.82 & 3.69 \\
\hline \multirow[t]{2}{*}{ (Work Exp.) ${ }^{2}$} & -0.0011 & -0.0008 & -0.0020 & -0.0006 & -0.0007 & -0.0006 & -0.0014 & -0.0005 \\
\hline & -4.4 & -4.74 & -3.74 & -1.83 & -2.72 & -3.07 & -3.88 & -2.44 \\
\hline \multirow[t]{2}{*}{ Central Province } & -0.116 & -0.035 & -0.296 & -0.176 & -0.260 & -0.154 & -0.151 & -0.096 \\
\hline & -2.57 & -0.79 & -3.25 & -2.28 & -4.85 & -3.3 & -1.91 & -2.23 \\
\hline \multirow[t]{2}{*}{ Coastal Province } & 0.219 & 0.261 & 0.050 & 0.182 & 0.162 & 0.083 & 0.010 & 0.177 \\
\hline & 4.72 & 6.03 & 0.5 & 2.11 & 2.68 & 1.4 & 0.13 & 3.31 \\
\hline \multirow[t]{2}{*}{ Big city } & 0.173 & 0.320 & 0.246 & 0.009 & 0.081 & 0.165 & -0.015 & 0.106 \\
\hline & 4.76 & 9.32 & 3.06 & 0.14 & 1.7 & 4.01 & -0.24 & 2.52 \\
\hline \multirow[t]{2}{*}{ Communist } & 0.231 & 0.196 & 0.130 & 0.155 & 0.168 & 0.142 & 0.016 & 0.154 \\
\hline & 5.19 & 5.96 & 1.39 & 2.04 & 3.2 & 2.84 & 0.25 & 3.25 \\
\hline \multirow[t]{2}{*}{ Vocational School } & 0.073 & 0.042 & 0.018 & 0.172 & 0.030 & 0.023 & 0.078 & -0.014 \\
\hline & 1.39 & 0.97 & 0.17 & 2.58 & 0.64 & 0.53 & 1.11 & -0.37 \\
\hline \multirow[t]{2}{*}{ Change in hukou } & -0.083 & -0.021 & -0.172 & -0.022 & -0.056 & 0.081 & -0.100 & 0.065 \\
\hline & -1.25 & -0.33 & -1.13 & -0.26 & -0.77 & 1.51 & -0.9 & 1.62 \\
\hline \multirow[t]{2}{*}{ Constant term } & -0.460 & -0.437 & 0.099 & 0.674 & 0.294 & 0.439 & 0.377 & 0.732 \\
\hline & -3.56 & -3.73 & 0.34 & 3.09 & 1.86 & 2.68 & 1.65 & 4.58 \\
\hline \# obs. & 2252 & 2500 & 293 & 413 & 775 & 785 & 424 & 753 \\
\hline $\mathbf{R}^{2}$ & 0.15 & 0.15 & 0.27 & 0.18 & 0.21 & 0.19 & 0.14 & 0.17 \\
\hline
\end{tabular}

Note: T-statistics in italics. 
Appendix A5 - Hourly wage functions by region, Year: 1995

\begin{tabular}{|c|c|c|c|c|c|c|c|c|c|c|}
\hline & \multicolumn{2}{|l|}{ Coast } & \multicolumn{2}{|l|}{ Centre } & \multicolumn{2}{|l|}{ West } & \multicolumn{2}{|c|}{ Municipality } & \multicolumn{2}{|c|}{ North-East } \\
\hline & Women & Men & Women & Men & Women & Men & Women & Men & Women & Men \\
\hline \multirow[t]{2}{*}{ Education } & 0.022 & 0.028 & 0.025 & 0.027 & 0.030 & 0.024 & 0.020 & 0.035 & 0.037 & 0.025 \\
\hline & 3.31 & 4.09 & 3.62 & 5.2 & 4.41 & 4.05 & 1.16 & 2.83 & 3.83 & 2.51 \\
\hline \multirow[t]{2}{*}{ Work Exp. } & 0.061 & 0.060 & 0.056 & 0.049 & 0.066 & 0.041 & 0.047 & 0.022 & 0.044 & 0.036 \\
\hline & 5.66 & 9.74 & 9.2 & 8.91 & 6.92 & 6.79 & 2.58 & 2.38 & 4.55 & 4.04 \\
\hline \multirow[t]{2}{*}{$\left(\right.$ Work Exp.) ${ }^{2}$} & -0.00129 & -0.00107 & -0.00092 & -0.00068 & -0.00110 & -0.00047 & -0.00076 & -0.00030 & -0.00079 & -0.00052 \\
\hline & -3.93 & -7.81 & -5.54 & -5.39 & -4.75 & -3.64 & -1.65 & -1.54 & -3.01 & -2.46 \\
\hline \multirow[t]{2}{*}{ Big city } & 0.117 & 0.106 & 0.120 & 0.103 & 0.147 & 0.127 & 0.000 & 0.000 & 0.397 & 0.339 \\
\hline & 2.91 & 3.02 & 3.93 & 3.83 & 5 & 5.02 & . & . & 7.52 & 5.33 \\
\hline \multirow[t]{2}{*}{ Communist } & 0.202 & 0.161 & 0.102 & 0.073 & 0.061 & 0.007 & 0.149 & 0.103 & 0.074 & 0.095 \\
\hline & 3.64 & 4.62 & 2.77 & 2.86 & 1.7 & 0.29 & 2.64 & 2.09 & 1.43 & 1.77 \\
\hline \multirow[t]{2}{*}{ Vocational School } & -0.157 & -0.044 & -0.124 & -0.062 & -0.099 & -0.098 & 0.025 & 0.004 & -0.127 & -0.037 \\
\hline & -3.32 & -0.98 & -3.19 & -1.64 & -2.36 & -2.41 & 0.28 & 0.06 & -2.32 & -0.58 \\
\hline \multirow[t]{2}{*}{ Change in hukou } & -0.119 & -0.025 & -0.077 & 0.056 & -0.021 & 0.041 & -0.115 & -0.005 & -0.095 & 0.098 \\
\hline & -1.84 & -0.61 & -1.82 & 2.02 & -0.4 & 1.19 & -1 & -0.06 & -1.01 & 1.19 \\
\hline \multirow[t]{2}{*}{ Constant term } & 0.232 & 0.128 & -0.164 & -0.104 & -0.292 & 0.050 & 0.163 & 0.427 & -0.378 & -0.097 \\
\hline & 2.21 & 1.18 & -1.63 & -1.26 & -2.4 & 0.46 & 0.5 & 2.51 & -2.53 & -0.58 \\
\hline \# obs. & 1017 & 1153 & 1745 & 2033 & 1438 & 1553 & 356 & 423 & 546 & 634 \\
\hline $\mathbf{R}^{2}$ & 0.16 & 0.21 & 0.19 & 0.18 & 0.20 & 0.21 & 0.15 & 0.10 & 0.27 & 0.16 \\
\hline
\end{tabular}

Note: T-statistics in italics. 
Appendix A6 - Hourly wage functions by region, Year: 2002

\begin{tabular}{|c|c|c|c|c|c|c|c|c|c|c|}
\hline & \multicolumn{2}{|l|}{ Coast } & \multicolumn{2}{|l|}{ Centre } & \multicolumn{2}{|l|}{ West } & \multicolumn{2}{|c|}{ Municipality } & \multicolumn{2}{|c|}{ North-East } \\
\hline & Women & Men & Women & Men & Women & Men & Women & Men & Women & Men \\
\hline Education & 8.15 & 8.86 & 8.52 & 10.08 & 9.04 & 11.93 & 4.34 & 5.28 & 4.77 & 5.83 \\
\hline \multirow[t]{2}{*}{ Work Exp. } & 0.069 & 0.051 & 0.053 & 0.040 & 0.051 & 0.060 & 0.061 & 0.050 & 0.013 & 0.018 \\
\hline & 5.77 & 5.12 & 4.42 & 4.62 & 4.96 & 5.99 & 3.83 & 4.28 & 0.97 & 1.85 \\
\hline \multirow[t]{2}{*}{ Big city } & 0.198 & 0.327 & 0.122 & 0.134 & 0.111 & 0.232 & 0.000 & 0.000 & 0.101 & 0.160 \\
\hline & 3.28 & 7.16 & 2.63 & 3.26 & 2.51 & 5.52 & . & . & 1.15 & 2.05 \\
\hline \multirow[t]{2}{*}{ Communist } & 0.322 & 0.324 & 0.108 & 0.209 & 0.197 & 0.258 & 0.207 & 0.124 & 0.093 & 0.189 \\
\hline & 4.61 & 6.32 & 2.08 & 5.25 & 4.19 & 6.7 & 2.37 & 1.84 & 1 & 3.14 \\
\hline Vocational School & 0.109 & 0.017 & 0.162 & 0.070 & 0.157 & 0.132 & -0.113 & -0.104 & 0.097 & 0.072 \\
\hline \multirow[t]{2}{*}{ Constant term } & -0.447 & -0.021 & -0.655 & -0.337 & -0.382 & -0.631 & 0.096 & 0.211 & -0.676 & 0.195 \\
\hline & -2.49 & -0.14 & -4.07 & -2.3 & -2.7 & -4.38 & 0.35 & 0.97 & -1.88 & 1.1 \\
\hline \# obs. & 818 & 994 & 1417 & 1883 & 1155 & 1421 & 367 & 432 & 431 & 619 \\
\hline $\mathbf{R}^{2}$ & 0.25 & 0.22 & 0.15 & 0.14 & 0.19 & 0.23 & 0.12 & 0.14 & 0.23 & 0.13 \\
\hline
\end{tabular}

Note: T-statistics in italics. 
Appendix B1 - Hours worked functions by ownership, Year: 1995

\begin{tabular}{|c|c|c|c|c|c|c|c|c|c|c|}
\hline & \multicolumn{2}{|c|}{ SOES } & \multicolumn{2}{|c|}{ UCEs } & \multicolumn{2}{|c|}{ PIEs } & \multicolumn{2}{|c|}{ FIEs } & \multicolumn{2}{|c|}{ GAIs } \\
\hline & Women & Men & Women & Men & Women & Men & Women & Men & Women & Men \\
\hline \multirow[t]{2}{*}{ Education } & -0.189 & 7.237 & 4.002 & -30.707 & 42.989 & -57.875 & 7.051 & -111.28 & 1.223 & 6.970 \\
\hline & -0.05 & 1.41 & 0.21 & -1.85 & 0.29 & -0.69 & 0.28 & -2.03 & 0.24 & 1.26 \\
\hline \multirow[t]{2}{*}{ Age } & -12.75 & 2.60 & -16.21 & -64.51 & -63.88 & -369.23 & 16.64 & -3.49 & 9.42 & 5.11 \\
\hline & -1.36 & 0.34 & -0.73 & -2.75 & -0.43 & -2.80 & 0.26 & -0.08 & 1.06 & 0.55 \\
\hline \multirow[t]{2}{*}{$(\text { Age })^{2}$} & 0.151 & -0.052 & 0.243 & 0.783 & 0.983 & 4.531 & -0.341 & 0.215 & -0.118 & -0.083 \\
\hline & 1.20 & -0.58 & 0.81 & 2.62 & 0.47 & 3.06 & -0.42 & 0.37 & -1.02 & -0.78 \\
\hline \multirow[t]{2}{*}{ Communist } & 3.68 & 52.24 & -38.94 & -55.99 & 369.48 & -1011.9 & -54.86 & 249.54 & 10.27 & 36.67 \\
\hline & 0.19 & 3.48 & -0.61 & -0.89 & 0.70 & -3.41 & -0.28 & 1.28 & 0.55 & 2.05 \\
\hline \multirow[t]{2}{*}{ Married } & -20.16 & 65.44 & -113.11 & 103.73 & 495.47 & 986.98 & -48.33 & -164.16 & 18.27 & -22.27 \\
\hline & -0.62 & 1.70 & -1.52 & 1.00 & 1.47 & 2.17 & -0.20 & -0.78 & 0.39 & -0.35 \\
\hline \multirow[t]{2}{*}{ Square root of household size } & 807.2 & -551.2 & -1215.6 & -13.3 & 7546.3 & 11043.6 & -716.1 & 733.2 & 311.8 & -85.2 \\
\hline & 2.60 & -1.55 & -1.61 & -0.02 & 0.88 & 3.46 & -0.22 & 0.22 & 0.81 & -0.21 \\
\hline \multirow{2}{*}{ Dependent elderly in the household } & 26.23 & 31.33 & 8.45 & 45.34 & -115.39 & 103.58 & -82.00 & 230.73 & -29.49 & -9.02 \\
\hline & 0.81 & 1.55 & 0.17 & 0.59 & -0.24 & 0.50 & -0.69 & 1.19 & -1.06 & -0.23 \\
\hline \multirow[t]{2}{*}{ Household size } & -184.5 & 153.6 & 347.3 & 66.8 & -1728.1 & -2544.8 & 316.8 & -228.1 & -67.0 & 23.5 \\
\hline & -2.27 & 1.62 & 1.75 & 0.30 & -0.77 & -3.46 & 0.36 & -0.26 & -0.65 & 0.22 \\
\hline \multirow{2}{*}{ Average education of adult hh members } & -6.46 & -13.80 & -18.13 & 5.13 & -27.79 & 17.09 & -42.88 & 39.56 & 2.54 & 2.59 \\
\hline & -1.37 & -2.83 & -1.37 & 0.38 & -0.35 & 0.34 & -1.50 & 1.00 & 0.47 & 0.36 \\
\hline \multirow[t]{2}{*}{ Average age of adult hh members } & -1.348 & -2.475 & -3.439 & -4.821 & -1.084 & 33.592 & 8.252 & -18.644 & 0.997 & 1.757 \\
\hline & -1.03 & -1.59 & -0.98 & -1.28 & -0.05 & 1.78 & 0.89 & -1.69 & 0.68 & 0.78 \\
\hline \multirow[t]{2}{*}{ Child of hh head } & -17.95 & 57.97 & -138.23 & -85.63 & 654.07 & -262.67 & -176.79 & 357.07 & 47.94 & -2.05 \\
\hline & -0.43 & 1.38 & -1.64 & -0.78 & 1.42 & -0.50 & -0.79 & 1.36 & 1.05 & -0.03 \\
\hline \multirow{2}{*}{ Vocational school } & -6.43 & 23.27 & 63.22 & -99.56 & 353.90 & 515.52 & 280.08 & -205.21 & 41.84 & 99.81 \\
\hline & -0.37 & 1.13 & 0.99 & -1.39 & 0.62 & 1.43 & 1.29 & -1.13 & 1.56 & 3.33 \\
\hline \multirow[t]{2}{*}{ Change in hukou } & 12.79 & 47.83 & 41.07 & -18.35 & -95.82 & 295.29 & -197.25 & 114.39 & -39.35 & -10.16 \\
\hline & 0.55 & 2.14 & 0.70 & -0.29 & -0.24 & 0.74 & -1.41 & 0.83 & -1.68 & -0.48 \\
\hline \multirow[t]{2}{*}{ Big city } & -13.01 & -40.41 & -79.68 & -58.00 & -474.62 & -607.03 & -47.13 & -15.81 & -22.34 & 17.43 \\
\hline & -1.02 & -2.96 & -2.55 & -1.25 & -1.38 & -2.34 & -0.36 & -0.15 & -1.32 & 0.90 \\
\hline \multirow[t]{2}{*}{ Coastal Province } & -23.659 & -0.631 & 91.032 & -9.099 & -149.21 & 259.689 & 33.716 & 234.191 & -21.663 & -58.345 \\
\hline & -1.33 & -0.03 & 2.00 & -0.18 & -0.51 & 0.84 & 0.24 & 1.06 & -0.93 & -2.35 \\
\hline \multirow[t]{2}{*}{ Central Province } & -37.467 & -31.587 & 23.360 & -25.180 & 475.089 & -70.934 & -50.924 & -147.87 & 4.407 & -13.147 \\
\hline & -2.65 & -1.99 & 0.58 & -0.45 & 1.31 & -0.18 & -0.25 & -0.67 & 0.25 & -0.66 \\
\hline \multirow[t]{2}{*}{ Constant term } & 1787.6 & 2814.6 & 3811.6 & 3710.3 & -4966.1 & -3184.6 & 2564.1 & 2965.1 & 1554.0 & 2043.4 \\
\hline & 5.25 & 7.79 & 4.32 & 4.28 & -0.52 & -0.75 & 0.93 & 0.85 & 3.85 & 5.11 \\
\hline \# obs. & 2551 & 3224 & 908 & 626 & 40 & 44 & 63 & 75 & 1445 & 1754 \\
\hline $\mathbf{R}^{2}$ & 0.02 & 0.02 & 0.03 & 0.05 & 0.35 & 0.66 & 0.32 & 0.32 & 0.01 & 0.01 \\
\hline
\end{tabular}

Note: T-statistics in italics. 
Appendix B2 - Hours worked functions by ownership, Year: 2002

\begin{tabular}{|c|c|c|c|c|c|c|c|c|c|c|}
\hline & \multicolumn{2}{|c|}{ SOEs } & \multicolumn{2}{|c|}{ UCEs } & \multicolumn{2}{|c|}{ PIEs } & \multicolumn{2}{|c|}{ FIEs } & \multicolumn{2}{|c|}{ GAIs } \\
\hline & Women & Men & Women & Men & Women & Men & Women & Men & Women & Men \\
\hline \multirow[t]{2}{*}{ Education } & -2.623 & -6.517 & 7.968 & -17.404 & -26.030 & -34.807 & -87.406 & -34.854 & -6.396 & 3.376 \\
\hline & -0.39 & -1.03 & 0.52 & -0.84 & -1.60 & -2.64 & -1.94 & -1.32 & -0.97 & 0.58 \\
\hline \multirow[t]{2}{*}{ Age } & -33.04 & 14.01 & 13.23 & 9.14 & -27.65 & -25.44 & 13.24 & -41.59 & -12.15 & 0.12 \\
\hline & -2.18 & 1.35 & 0.40 & 0.27 & -0.99 & -0.94 & 0.18 & -0.84 & -0.94 & 0.01 \\
\hline \multirow[t]{2}{*}{$(\text { Age })^{2}$} & 0.417 & -0.182 & -0.240 & -0.301 & 0.429 & 0.273 & -0.180 & 0.527 & 0.109 & 0.015 \\
\hline & 2.16 & -1.52 & -0.55 & -0.71 & 1.11 & 0.84 & -0.18 & 0.90 & 0.65 & 0.10 \\
\hline \multirow{2}{*}{ Communist } & 43.55 & -18.48 & -123.21 & 5.04 & -94.20 & -188.15 & -37.36 & -51.00 & -5.31 & -11.22 \\
\hline & 1.77 & -0.92 & -1.97 & 0.06 & -1.17 & -3.25 & -0.28 & -0.47 & -0.25 & -0.54 \\
\hline \multirow[t]{2}{*}{ Married } & -41.46 & 74.44 & -121.30 & 1.98 & 89.66 & 11.47 & 143.08 & 68.85 & 28.94 & 45.58 \\
\hline & -0.89 & 1.27 & -0.94 & 0.02 & 0.77 & 0.08 & 0.54 & 0.41 & 0.65 & 1.10 \\
\hline \multirow[t]{2}{*}{ Square root of household size } & 830.6 & 326.9 & -11.4 & -283.1 & -649.2 & -2062.2 & -3905.6 & 1659.4 & 335.0 & 173.4 \\
\hline & 1.49 & 0.64 & -0.01 & -0.20 & -0.49 & -1.66 & -1.30 & 0.62 & 0.92 & 0.41 \\
\hline \multirow[t]{2}{*}{ Dependent elderly in the household } & 26.26 & -9.56 & -137.58 & -45.28 & 30.03 & -22.32 & -472.73 & -178.08 & -5.97 & -24.96 \\
\hline & 0.64 & -0.24 & -2.10 & -0.45 & 0.39 & -0.31 & -1.73 & -1.18 & -0.17 & -0.76 \\
\hline \multirow[t]{2}{*}{ Household size } & -195.6 & -71.8 & 2.5 & 131.1 & 224.2 & 595.5 & 1183.7 & -434.7 & -92.2 & -73.2 \\
\hline & -1.27 & -0.50 & 0.01 & 0.36 & 0.61 & 1.78 & 1.40 & -0.60 & -0.95 & -0.66 \\
\hline \multirow{2}{*}{ Average education of adult hh members } & -4.20 & 0.54 & -12.69 & 1.53 & -13.37 & -5.80 & 36.21 & -18.39 & -0.33 & -9.18 \\
\hline & -0.53 & 0.08 & -0.72 & 0.06 & -0.80 & -0.37 & 0.72 & -0.55 & -0.05 & -1.34 \\
\hline \multirow[t]{2}{*}{ Average age of adult hh members } & -0.694 & 0.007 & 7.532 & 8.863 & -9.613 & -6.966 & -3.581 & -14.226 & 2.493 & -3.547 \\
\hline & -0.28 & 0.00 & 1.65 & 1.35 & -1.75 & -1.50 & -0.21 & -1.54 & 1.26 & -1.74 \\
\hline \multirow[t]{2}{*}{ Child of hh head } & 34.37 & 53.30 & -2.65 & -340.70 & 163.02 & -55.38 & 433.34 & 250.16 & -57.24 & 126.82 \\
\hline & 0.50 & 0.85 & -0.02 & -2.33 & 1.19 & -0.48 & 0.93 & 1.07 & -1.07 & 2.53 \\
\hline \multirow{2}{*}{ Vocational school } & -68.22 & 6.03 & -41.95 & -82.20 & -64.17 & -64.33 & -60.35 & 133.34 & -16.86 & -27.71 \\
\hline & -2.56 & 0.27 & -0.62 & -0.90 & -0.96 & -1.05 & -0.48 & 1.30 & -0.81 & -1.41 \\
\hline \multirow{2}{*}{ Change in hukou } & 49.48 & 90.66 & 102.41 & 118.24 & 168.87 & 104.17 & -138.86 & 343.96 & 32.29 & 6.76 \\
\hline & 1.08 & 2.67 & 1.07 & 1.24 & 1.96 & 1.19 & -0.70 & 1.32 & 1.06 & 0.29 \\
\hline \multirow[t]{2}{*}{ Big city } & -16.38 & -10.46 & -122.68 & -64.23 & -23.11 & -109.65 & -130.13 & -108.69 & 48.57 & 15.15 \\
\hline & -0.74 & -0.54 & -2.35 & -1.01 & -0.40 & -2.12 & -0.85 & -1.11 & 2.13 & 0.67 \\
\hline \multirow[t]{2}{*}{ Coastal Province } & -124.08 & -6.923 & 70.339 & -23.539 & -119.96 & -117.79 & 169.409 & -120.25 & -79.970 & 14.648 \\
\hline & -4.29 & -0.26 & 0.97 & -0.23 & -1.81 & -1.94 & 0.77 & -0.66 & -3.14 & 0.51 \\
\hline \multirow[t]{2}{*}{ Central Province } & -13.107 & 10.842 & 155.477 & -22.931 & 27.400 & 65.043 & 99.163 & -255.05 & 19.988 & 16.797 \\
\hline & -0.48 & 0.49 & 2.48 & -0.26 & 0.42 & 1.06 & 0.50 & -1.55 & 0.84 & 0.79 \\
\hline \multirow[t]{2}{*}{ Constant term } & 2094.7 & 1561.8 & 1899.7 & 2493.8 & 3984.6 & 5691.7 & 5808.3 & 2661.1 & 2058.0 & 2167.1 \\
\hline & 3.68 & 3.01 & 1.77 & 1.64 & 3.02 & 4.66 & 2.25 & 0.97 & 5.11 & 4.18 \\
\hline \# obs. & 1315 & 2056 & 383 & 295 & 781 & 986 & 86 & 125 & 1368 & 1686 \\
\hline $\mathbf{R}^{2}$ & 0.05 & 0.01 & 0.07 & 0.04 & 0.06 & 0.08 & 0.29 & 0.22 & 0.02 & 0.01 \\
\hline
\end{tabular}


Appendix B3 - Hours worked functions by economic sector, Year: 1995

\begin{tabular}{|c|c|c|c|c|c|c|c|c|}
\hline & \multicolumn{2}{|c|}{ Competitive } & \multicolumn{2}{|c|}{ Oligopolistic } & \multicolumn{2}{|c|}{ Public Services } & \multicolumn{2}{|c|}{ Government } \\
\hline & Women & Men & Women & Men & Women & Men & Women & Men \\
\hline \multirow[t]{2}{*}{ Education } & -3.304 & 0.331 & 3.612 & -38.315 & -3.807 & 2.302 & 11.438 & 10.413 \\
\hline & -0.51 & 0.06 & 0.26 & -1.50 & -0.52 & 0.28 & 1.66 & 1.09 \\
\hline \multirow[t]{2}{*}{ Age } & -11.48 & -3.88 & -29.77 & -10.85 & 14.21 & 19.11 & 3.28 & -14.77 \\
\hline & -1.07 & -0.47 & -1.30 & -0.40 & 1.05 & 1.14 & 0.22 & -1.00 \\
\hline \multirow[t]{2}{*}{$(\text { Age })^{2}$} & 0.137 & 0.029 & 0.464 & 0.205 & -0.198 & -0.219 & -0.026 & 0.074 \\
\hline & 0.94 & 0.29 & 1.55 & 0.61 & -1.13 & -1.14 & -0.12 & 0.43 \\
\hline \multirow[t]{2}{*}{ Communist } & -17.45 & 19.14 & 3.37 & 14.31 & 11.33 & 38.76 & 17.16 & 67.69 \\
\hline & -0.82 & 1.18 & 0.04 & 0.30 & 0.44 & 1.22 & 0.58 & 2.32 \\
\hline \multirow[t]{2}{*}{ Married } & -65.51 & 76.88 & -105.26 & -325.50 & -30.87 & -78.56 & 20.32 & 225.64 \\
\hline & -1.93 & 1.91 & -1.30 & -1.94 & -0.50 & -0.92 & 0.42 & 1.46 \\
\hline \multirow[t]{2}{*}{ Square root of household size } & 336.5 & -591.5 & -1334.6 & -519.1 & -137.5 & -644.0 & -105.1 & 913.7 \\
\hline & 1.00 & -1.66 & -1.22 & -0.77 & -0.28 & -1.05 & -0.18 & 1.16 \\
\hline \multirow[t]{2}{*}{ Dependent elderly in the household } & 3.79 & 14.27 & 83.33 & 34.58 & -31.20 & 36.01 & -71.99 & -92.81 \\
\hline & 0.13 & 0.53 & 1.82 & 0.51 & -0.63 & 0.72 & -1.79 & -1.49 \\
\hline \multirow[t]{2}{*}{ Household size } & -57.3 & 177.4 & 397.3 & 136.5 & 74.5 & 201.4 & 20.9 & -229.2 \\
\hline & -0.64 & 1.87 & 1.34 & 0.80 & 0.58 & 1.23 & 0.13 & -1.14 \\
\hline \multirow[t]{2}{*}{ Average education of adult hh members } & -5.57 & -10.22 & -10.27 & 3.90 & 1.92 & 15.82 & -8.99 & -2.01 \\
\hline & -1.00 & -2.01 & -0.79 & 0.21 & 0.25 & 1.42 & -1.01 & -0.19 \\
\hline \multirow[t]{2}{*}{ Average age of adult hh members } & -1.065 & -1.728 & -9.993 & -7.324 & 2.816 & 0.062 & -0.033 & 6.875 \\
\hline & -0.68 & -1.13 & -2.69 & -1.66 & 1.34 & 0.02 & -0.01 & 1.87 \\
\hline \multirow[t]{2}{*}{ Child of hh head } & -72.49 & 64.99 & -15.21 & -149.58 & 2.53 & -16.50 & 61.38 & 28.96 \\
\hline & -1.66 & 1.41 & -0.16 & -1.14 & 0.04 & -0.18 & 0.94 & 0.18 \\
\hline \multirow[t]{2}{*}{ Vocational school } & 17.95 & 12.59 & 37.77 & -83.85 & -1.83 & 166.32 & 47.46 & 85.32 \\
\hline & 0.75 & 0.60 & 0.62 & -0.90 & -0.05 & 2.50 & 0.99 & 1.58 \\
\hline \multirow[t]{2}{*}{ Change in hukou } & 1.91 & 32.19 & 93.33 & 43.52 & -48.79 & -1.20 & 17.12 & -11.46 \\
\hline & 0.07 & 1.40 & 1.30 & 0.62 & -1.38 & -0.03 & 0.47 & -0.33 \\
\hline \multirow[t]{2}{*}{ Big city } & -31.47 & -59.26 & -49.41 & 108.56 & -38.72 & 13.83 & 20.12 & 27.52 \\
\hline & -2.32 & -3.99 & -1.01 & 1.93 & -1.77 & 0.47 & 0.67 & 0.84 \\
\hline \multirow[t]{2}{*}{ Coastal Province } & 32.838 & 29.734 & 58.594 & -2.980 & -37.314 & -84.781 & -9.381 & -39.783 \\
\hline & 1.94 & 1.96 & 1.08 & -0.05 & -1.42 & -2.64 & -0.29 & -1.18 \\
\hline \multirow[t]{2}{*}{ Constant term } & 2217.1 & 2921.8 & 4225.6 & 3748.1 & 1927.7 & 2142.5 & 2138.6 & 1197.0 \\
\hline & 5.68 & 8.07 & 3.79 & 5.05 & 3.59 & 3.46 & 4.00 & 1.55 \\
\hline \# obs. & 3019 & 3324 & 312 & 295 & 791 & 675 & 477 & 772 \\
\hline $\mathbf{R}^{2}$ & 0.02 & 0.03 & 0.08 & 0.08 & 0.02 & 0.03 & 0.01 & 0.03 \\
\hline
\end{tabular}

Note: T-statistics in italics. 
Appendix B4 - Hours worked functions by economic sector, Year: 2002

\begin{tabular}{|c|c|c|c|c|c|c|c|c|}
\hline & \multicolumn{2}{|c|}{ Competitive } & \multicolumn{2}{|c|}{ Oligopolistic } & \multicolumn{2}{|c|}{ Public Services } & \multicolumn{2}{|c|}{ Government } \\
\hline & Women & Men & Women & Men & Women & Men & Women & Men \\
\hline \multirow[t]{2}{*}{ Education } & -18.246 & -19.778 & 10.465 & -4.982 & 12.067 & 3.859 & -6.475 & -10.598 \\
\hline & -2.17 & -2.71 & 0.79 & -0.42 & 1.17 & 0.36 & -0.82 & -1.42 \\
\hline \multirow{2}{*}{ Age } & -24.89 & -22.42 & 9.52 & 17.11 & -12.38 & -9.83 & -54.07 & 2.19 \\
\hline & -1.63 & -1.55 & 0.39 & 0.82 & -0.66 & -0.45 & -2.03 & 0.15 \\
\hline \multirow{2}{*}{$(\text { Age })^{2}$} & 0.316 & 0.225 & -0.222 & -0.192 & 0.141 & 0.154 & 0.654 & -0.069 \\
\hline & 1.57 & 1.34 & -0.71 & -0.78 & 0.56 & 0.58 & 1.86 & -0.41 \\
\hline \multirow[t]{2}{*}{ Communist } & -37.99 & -102.61 & -27.80 & -50.79 & -57.21 & -36.28 & 53.95 & -7.25 \\
\hline & -1.25 & -3.97 & -0.72 & -1.06 & -1.79 & -1.15 & 1.45 & -0.23 \\
\hline \multirow{2}{*}{ Married } & -74.71 & 10.93 & 132.44 & 78.83 & 24.66 & 10.40 & 9.74 & 68.10 \\
\hline & -1.46 & 0.16 & 1.23 & 0.65 & 0.34 & 0.13 & 0.12 & 1.34 \\
\hline \multirow[t]{2}{*}{ Square root of household size } & -687.2 & -1640.7 & 1453.9 & 2061.1 & 1027.8 & -605.5 & -227.0 & 976.3 \\
\hline & -1.08 & -2.23 & 1.95 & 1.92 & 1.78 & -0.62 & -0.32 & 2.05 \\
\hline \multirow[t]{2}{*}{ Dependent elderly in the household } & -65.03 & -45.31 & -91.37 & -8.25 & 78.14 & -7.88 & -21.70 & -34.08 \\
\hline & -1.65 & -1.05 & -1.20 & -0.10 & 1.04 & -0.13 & -0.39 & -0.80 \\
\hline \multirow[t]{2}{*}{ Household size } & 241.2 & 478.7 & -366.0 & -501.1 & -326.6 & 124.4 & 122.7 & -269.6 \\
\hline & 1.34 & 2.36 & -1.89 & -1.73 & -2.05 & 0.46 & 0.65 & -2.25 \\
\hline \multirow[t]{2}{*}{ Average education of adult hh members } & -12.06 & -8.60 & -2.25 & 18.66 & -16.46 & -10.66 & 4.33 & -2.51 \\
\hline & -1.38 & -0.99 & -0.17 & 1.31 & -1.28 & -0.86 & 0.38 & -0.27 \\
\hline \multirow[t]{2}{*}{ Average age of adult hh members } & -5.105 & -5.044 & 6.682 & 1.035 & 0.912 & -5.934 & 3.568 & 1.217 \\
\hline & -1.89 & -1.97 & 1.53 & 0.22 & 0.24 & -1.79 & 0.83 & 0.46 \\
\hline \multirow{2}{*}{ Child of hh head } & 75.25 & -21.98 & 89.46 & 107.29 & -80.34 & 98.08 & -137.99 & 20.41 \\
\hline & 1.18 & -0.28 & 0.71 & 0.93 & -0.87 & 1.01 & -1.24 & 0.28 \\
\hline \multirow[t]{2}{*}{ Vocational school } & -50.17 & 10.25 & -41.33 & -66.01 & -57.01 & -63.16 & 56.49 & 15.47 \\
\hline & -1.70 & 0.33 & -0.85 & -1.55 & -1.96 & -2.12 & 1.40 & 0.54 \\
\hline \multirow[t]{2}{*}{ Change in hukou } & 100.93 & 86.65 & 5.47 & 66.39 & 73.87 & 45.76 & 14.87 & -9.52 \\
\hline & 2.11 & 2.08 & 0.07 & 1.10 & 1.61 & 1.16 & 0.38 & -0.30 \\
\hline \multirow[t]{2}{*}{ Big city } & -46.82 & -134.44 & -17.01 & 62.16 & 14.50 & -21.55 & -23.12 & 47.72 \\
\hline & -1.76 & -5.50 & -0.37 & 1.23 & 0.49 & -0.65 & -0.57 & 1.41 \\
\hline \multirow[t]{2}{*}{ Coastal Province } & -130.508 & -39.563 & -81.650 & -87.988 & -82.749 & 43.092 & -10.280 & -10.137 \\
\hline & -5.14 & -1.57 & -1.90 & -1.89 & -2.49 & 1.00 & -0.22 & -0.27 \\
\hline \multirow[t]{2}{*}{ Constant term } & 3830.3 & 4837.8 & 227.9 & -503.7 & 1625.9 & 3249.3 & 2991.9 & 1344.0 \\
\hline & 6.01 & 6.72 & 0.25 & -0.46 & 2.44 & 3.15 & 4.46 & 2.38 \\
\hline \# obs. & 2252 & 2500 & 293 & 413 & 775 & 785 & 424 & 753 \\
\hline $\mathbf{R}^{2}$ & 0.06 & 0.06 & 0.07 & 0.05 & 0.03 & 0.02 & 0.04 & 0.02 \\
\hline
\end{tabular}

Note: T-statistics in italics. 
Appendix B5 - Hours worked functions by region, Year: 1995

\begin{tabular}{|c|c|c|c|c|c|c|c|c|c|c|}
\hline & \multicolumn{2}{|c|}{ Coast } & \multicolumn{2}{|c|}{ Centre } & \multicolumn{2}{|c|}{ West } & \multicolumn{2}{|c|}{ Municipality } & \multicolumn{2}{|c|}{ North-East } \\
\hline & Women & Men & Women & Men & Women & Men & Women & Men & Women & Men \\
\hline \multirow[t]{2}{*}{ Education } & -6.264 & -23.347 & 7.369 & 6.381 & 5.667 & 7.753 & 9.641 & 0.575 & -18.242 & 8.579 \\
\hline & -0.57 & -2.69 & 1.00 & 1.08 & 0.76 & 1.02 & 0.94 & 0.04 & -1.64 & 0.80 \\
\hline \multirow{2}{*}{ Age } & -11.534 & 6.296 & -19.792 & -19.536 & 6.024 & 8.235 & -20.964 & 39.445 & 2.323 & -11.361 \\
\hline & -0.72 & 0.49 & -1.77 & -1.89 & 0.48 & 0.77 & -1.72 & 1.43 & 0.10 & -0.53 \\
\hline \multirow[t]{2}{*}{$(\text { Age })^{2}$} & 0.174 & -0.081 & 0.249 & 0.238 & -0.089 & -0.125 & 0.231 & -0.481 & -0.025 & 0.143 \\
\hline & 0.79 & -0.55 & 1.69 & 1.89 & -0.51 & -0.98 & 1.41 & -1.65 & -0.09 & 0.54 \\
\hline \multirow{2}{*}{ Communist } & -69.536 & -36.777 & -20.465 & 35.000 & 0.357 & 56.788 & 92.100 & 82.706 & 22.086 & -5.994 \\
\hline & -1.75 & -1.36 & -0.84 & 1.79 & 0.02 & 2.81 & 2.11 & 1.67 & 0.50 & -0.15 \\
\hline \multirow[t]{2}{*}{ Married } & -31.415 & -23.390 & -51.422 & 93.395 & -50.179 & 66.056 & 10.205 & -34.288 & -14.583 & 62.072 \\
\hline & -0.50 & -0.32 & -1.08 & 1.57 & -1.01 & 1.16 & 0.26 & -0.20 & -0.19 & 0.84 \\
\hline \multirow[t]{2}{*}{ Square root of household size } & -892.9 & -821.5 & 869.8 & -252.3 & 816.7 & 231.8 & 440.8 & -1325.6 & -773.4 & -1775.1 \\
\hline & -1.97 & -1.54 & 1.64 & -0.55 & 2.01 & 0.56 & 0.74 & -0.95 & -1.03 & -1.69 \\
\hline \multirow[t]{2}{*}{ Dependent elderly in the household } & -50.132 & -6.811 & -10.238 & 7.812 & 61.673 & 21.094 & 50.098 & 24.713 & 15.994 & -9.675 \\
\hline & -1.30 & -0.15 & -0.29 & 0.24 & 1.54 & 0.56 & 1.73 & 0.43 & 0.15 & -0.19 \\
\hline \multirow[t]{2}{*}{ Household size } & 291.4 & 236.6 & -213.7 & 60.9 & -195.6 & -44.2 & -138.1 & 341.1 & 266.3 & 492.1 \\
\hline & 2.39 & 1.66 & -1.56 & 0.51 & -1.81 & -0.41 & -0.87 & 0.93 & 1.26 & 1.79 \\
\hline \multirow{2}{*}{ Average education of adult hh members } & -10.829 & 1.177 & -5.540 & -8.647 & -9.496 & -14.536 & -13.949 & 8.784 & 7.141 & -6.209 \\
\hline & -1.22 & 0.13 & -0.76 & -1.35 & -1.51 & -2.25 & -1.55 & 0.50 & 0.52 & -0.50 \\
\hline \multirow[t]{2}{*}{ Average age of adult hh members } & 0.477 & -1.544 & -1.936 & -3.920 & 0.313 & -0.090 & -2.366 & 0.689 & -0.421 & -0.083 \\
\hline & 0.19 & -0.71 & -0.91 & -1.82 & 0.16 & -0.04 & -1.12 & 0.14 & -0.14 & -0.02 \\
\hline \multirow[t]{2}{*}{ Child of hh head } & 75.484 & 148.396 & -87.927 & 130.582 & -38.511 & 43.248 & -80.981 & 33.353 & 0.554 & -26.255 \\
\hline & 1.23 & 1.85 & -1.52 & 2.00 & -0.61 & 0.58 & -2.03 & 0.26 & 0.01 & -0.30 \\
\hline \multirow[t]{2}{*}{ Vocational school } & 58.201 & -44.194 & 51.005 & 78.304 & 21.001 & 37.609 & -28.868 & -29.766 & 5.420 & 52.365 \\
\hline & 1.17 & -1.18 & 1.75 & 2.77 & 0.77 & 1.02 & -0.64 & -0.52 & 0.16 & 1.19 \\
\hline \multirow[t]{2}{*}{ Change in hukou } & 30.322 & 44.688 & 31.066 & 23.456 & -38.681 & -9.469 & -109.763 & 101.950 & 22.055 & -3.420 \\
\hline & 0.73 & 1.38 & 0.98 & 0.93 & -1.30 & -0.35 & -1.85 & 1.06 & 0.57 & -0.05 \\
\hline \multirow[t]{2}{*}{ Big city } & -49.381 & -42.404 & -26.139 & -13.340 & -29.187 & -17.176 & - & - & -60.718 & -99.489 \\
\hline & -1.91 & -1.67 & -1.29 & -0.72 & -1.56 & -0.76 & - & - & -2.19 & -2.25 \\
\hline \multirow[t]{2}{*}{ Constant term } & 3227.2 & 3156.1 & 1788.4 & 2880.1 & 1371.2 & 1843.8 & 2418.4 & 2631.6 & 2857.8 & 3993.7 \\
\hline & 6.16 & 5.55 & 3.29 & 6.55 & 3.01 & 4.04 & 4.27 & 2.17 & 3.51 & 3.82 \\
\hline \# obs. & 1017 & 1153 & 1745 & 2033 & 1438 & 1553 & 356 & 423 & 546 & 634 \\
\hline $\mathbf{R}^{2}$ & 0.07 & 0.07 & 0.01 & 0.02 & 0.02 & 0.02 & 0.06 & 0.03 & 0.05 & 0.03 \\
\hline
\end{tabular}


Appendix B6 - Hours worked functions by region, Year: 2002

\begin{tabular}{|c|c|c|c|c|c|c|c|c|c|c|}
\hline & \multicolumn{2}{|c|}{ Coast } & \multicolumn{2}{|c|}{ Centre } & \multicolumn{2}{|c|}{ West } & \multicolumn{2}{|c|}{ Municipality } & \multicolumn{2}{|c|}{ North-East } \\
\hline & Women & Men & Women & Men & Women & Men & Women & Men & Women & Men \\
\hline Education & $\begin{array}{c}-24.680 \\
-1.76\end{array}$ & $\begin{array}{c}-15.043 \\
-1.27\end{array}$ & $\begin{array}{r}-29.159 \\
-3.02\end{array}$ & $\begin{array}{c}-16.376 \\
-1.96\end{array}$ & $\begin{array}{c}-1.805 \\
-0.20\end{array}$ & $\begin{array}{c}-22.933 \\
-3.03\end{array}$ & $\begin{array}{c}12.724 \\
0.96\end{array}$ & $\begin{array}{c}-32.527 \\
-2.51\end{array}$ & $\begin{array}{c}-27.263 \\
-2.00\end{array}$ & $\begin{array}{l}-7.632 \\
-0.71\end{array}$ \\
\hline Age & $\begin{array}{c}-32.931 \\
-1.39\end{array}$ & $\begin{array}{c}-8.793 \\
-0.37\end{array}$ & $\begin{array}{r}-30.722 \\
-1.47\end{array}$ & $\begin{array}{c}15.195 \\
0.93\end{array}$ & $\begin{array}{c}-28.039 \\
-1.41\end{array}$ & $\begin{array}{c}-40.128 \\
-2.11\end{array}$ & $\begin{array}{c}-27.231 \\
-1.04\end{array}$ & $\begin{array}{c}1.933 \\
0.10\end{array}$ & $\begin{array}{c}-15.592 \\
-0.57\end{array}$ & $\begin{array}{c}4.233 \\
0.16\end{array}$ \\
\hline$(\text { Age })^{2}$ & $\begin{array}{c}0.385 \\
1.25\end{array}$ & $\begin{array}{c}0.045 \\
0.16\end{array}$ & $\begin{array}{r}0.377 \\
1.31\end{array}$ & $\begin{array}{l}-0.175 \\
-0.89\end{array}$ & $\begin{array}{c}0.373 \\
1.45\end{array}$ & $\begin{array}{c}0.429 \\
1.99\end{array}$ & $\begin{array}{c}0.129 \\
0.41\end{array}$ & $\begin{array}{l}-0.072 \\
-0.32\end{array}$ & $\begin{array}{c}0.237 \\
0.71\end{array}$ & $\begin{array}{l}-0.104 \\
-0.36\end{array}$ \\
\hline Communist & $\begin{array}{c}-28.556 \\
-0.72\end{array}$ & $\begin{array}{c}-86.791 \\
-2.11\end{array}$ & $\begin{array}{r}-27.940 \\
-0.87\end{array}$ & $\begin{array}{c}-122.885 \\
-4.67\end{array}$ & $\begin{array}{c}-58.873 \\
-1.88\end{array}$ & $\begin{array}{c}-123.171 \\
-4.36\end{array}$ & $\begin{array}{c}20.700 \\
0.39\end{array}$ & $\begin{array}{c}30.892 \\
0.59\end{array}$ & $\begin{array}{c}-107.644 \\
-2.08\end{array}$ & $\begin{array}{c}-79.280 \\
-1.93\end{array}$ \\
\hline Married & $\begin{array}{c}32.192 \\
0.36\end{array}$ & $\begin{array}{c}47.179 \\
0.50\end{array}$ & $\begin{array}{r}-36.532 \\
-0.52\end{array}$ & $\begin{array}{c}33.559 \\
0.45\end{array}$ & $\begin{array}{c}-47.063 \\
-0.68\end{array}$ & $\begin{array}{c}19.562 \\
0.19\end{array}$ & $\begin{array}{c}171.904 \\
1.39\end{array}$ & $\begin{array}{c}-94.527 \\
-0.87\end{array}$ & $\begin{array}{c}11.022 \\
0.11\end{array}$ & $\begin{array}{c}-73.636 \\
-0.43\end{array}$ \\
\hline Square root of household size & $\begin{array}{l}-559.1 \\
-0.70\end{array}$ & $\begin{array}{c}513.4 \\
0.63\end{array}$ & $\begin{array}{r}-154.5 \\
-0.18\end{array}$ & $\begin{array}{l}-490.2 \\
-0.64\end{array}$ & $\begin{array}{c}850.9 \\
1.20\end{array}$ & $\begin{array}{l}-975.2 \\
-0.92\end{array}$ & $\begin{array}{c}-1008.2 \\
-0.66\end{array}$ & $\begin{array}{c}390.0 \\
0.43\end{array}$ & $\begin{array}{c}-1777.0 \\
-1.39\end{array}$ & $\begin{array}{c}-1902.1 \\
-1.33\end{array}$ \\
\hline Dependent elderly in the household & $\begin{array}{c}-84.368 \\
-1.39\end{array}$ & $\begin{array}{c}-93.597 \\
-1.64\end{array}$ & $\begin{array}{r}-11.294 \\
-0.22\end{array}$ & $\begin{array}{c}-64.155 \\
-1.44\end{array}$ & $\begin{array}{c}-62.999 \\
-1.10\end{array}$ & $\begin{array}{c}20.735 \\
0.28\end{array}$ & $\begin{array}{c}-38.608 \\
-0.62\end{array}$ & $\begin{array}{c}146.980 \\
1.52\end{array}$ & $\begin{array}{c}51.046 \\
0.78\end{array}$ & $\begin{array}{c}26.550 \\
0.44\end{array}$ \\
\hline Household size & $\begin{array}{c}176.2 \\
0.84\end{array}$ & $\begin{array}{c}-105.7 \\
-0.48\end{array}$ & $\begin{array}{l}83.4 \\
0.35\end{array}$ & $\begin{array}{c}148.4 \\
0.71\end{array}$ & $\begin{array}{c}-191.9 \\
-0.89\end{array}$ & $\begin{array}{c}286.9 \\
0.98\end{array}$ & $\begin{array}{c}221.3 \\
0.60\end{array}$ & $\begin{array}{c}-110.7 \\
-0.45\end{array}$ & $\begin{array}{c}479.5 \\
1.40\end{array}$ & $\begin{array}{c}521.5 \\
1.32\end{array}$ \\
\hline Average education of adult hh members & $\begin{array}{c}0.906 \\
0.07\end{array}$ & $\begin{array}{c}-17.912 \\
-1.41\end{array}$ & $\begin{array}{r}2.403 \\
0.25\end{array}$ & $\begin{array}{l}-9.288 \\
-1.00\end{array}$ & $\begin{array}{c}-27.228 \\
-2.50\end{array}$ & $\begin{array}{c}-11.040 \\
-1.20\end{array}$ & $\begin{array}{l}-4.438 \\
-0.31\end{array}$ & $\begin{array}{c}27.861 \\
1.50\end{array}$ & $\begin{array}{c}-13.005 \\
-0.90\end{array}$ & $\begin{array}{c}-11.400 \\
-0.84\end{array}$ \\
\hline Average age of adult hh members & $\begin{array}{c}0.379 \\
0.11\end{array}$ & $\begin{array}{c}-0.467 \\
-0.13\end{array}$ & $\begin{array}{r}0.376 \\
0.11\end{array}$ & $\begin{array}{l}-3.966 \\
-1.24\end{array}$ & $\begin{array}{c}-6.141 \\
-1.62\end{array}$ & $\begin{array}{l}-6.354 \\
-2.02\end{array}$ & $\begin{array}{c}8.063 \\
1.63\end{array}$ & $\begin{array}{c}-3.504 \\
-0.84\end{array}$ & $\begin{array}{c}-10.772 \\
-2.64\end{array}$ & $\begin{array}{c}-2.938 \\
-0.61\end{array}$ \\
\hline Child of hh head & $\begin{array}{c}95.840 \\
0.87\end{array}$ & $\begin{array}{c}-42.404 \\
-0.51\end{array}$ & $\begin{array}{r}-10.068 \\
-0.14\end{array}$ & $\begin{array}{c}89.408 \\
1.02\end{array}$ & $\begin{array}{c}23.018 \\
0.23\end{array}$ & $\begin{array}{c}-51.560 \\
-0.44\end{array}$ & $\begin{array}{c}-92.786 \\
-0.62\end{array}$ & $\begin{array}{c}-45.695 \\
-0.49\end{array}$ & $\begin{array}{c}111.619 \\
0.98\end{array}$ & $\begin{array}{c}-168.735 \\
-1.24\end{array}$ \\
\hline Vocational school & $\begin{array}{c}-47.683 \\
-1.07\end{array}$ & $\begin{array}{l}-3.256 \\
-0.08\end{array}$ & $\begin{array}{r}-108.498 \\
-3.92\end{array}$ & $\begin{array}{c}-67.207 \\
-2.49\end{array}$ & $\begin{array}{c}-76.243 \\
-2.40\end{array}$ & $\begin{array}{c}-45.343 \\
-1.58\end{array}$ & $\begin{array}{c}34.987 \\
0.74\end{array}$ & $\begin{array}{c}88.532 \\
1.72\end{array}$ & $\begin{array}{c}15.963 \\
0.38\end{array}$ & $\begin{array}{c}-35.430 \\
-0.89\end{array}$ \\
\hline Change in hukou & $\begin{array}{c}112.556 \\
1.90\end{array}$ & $\begin{array}{c}-65.124 \\
-1.40\end{array}$ & $\begin{array}{r}85.118 \\
1.97\end{array}$ & $\begin{array}{c}45.600 \\
1.40\end{array}$ & $\begin{array}{c}-15.019 \\
-0.26\end{array}$ & $\begin{array}{c}51.905 \\
1.23\end{array}$ & $\begin{array}{c}25.631 \\
0.28\end{array}$ & $\begin{array}{c}247.411 \\
1.50\end{array}$ & $\begin{array}{c}-72.604 \\
-0.56\end{array}$ & $\begin{array}{c}201.230 \\
1.83\end{array}$ \\
\hline Big city & $\begin{array}{c}-40.351 \\
-1.16\end{array}$ & $\begin{array}{c}-99.741 \\
-2.90\end{array}$ & $\begin{array}{r}11.917 \\
0.37\end{array}$ & $\begin{array}{l}-8.247 \\
-0.29\end{array}$ & $\begin{array}{c}-10.235 \\
-0.31\end{array}$ & $\begin{array}{c}-65.638 \\
-2.17\end{array}$ & $\begin{array}{c}0.000 \\
.\end{array}$ & $\begin{array}{c}0.000 \\
.\end{array}$ & $\begin{array}{c}91.759 \\
1.57\end{array}$ & $\begin{array}{c}19.450 \\
0.37\end{array}$ \\
\hline Constant term & $\begin{array}{c}3499.4 \\
3.71\end{array}$ & $\begin{array}{c}2413.3 \\
2.57\end{array}$ & $\begin{array}{r}3188.2 \\
3.99\end{array}$ & $\begin{array}{c}2823.1 \\
3.71\end{array}$ & $\begin{array}{c}2452.1 \\
3.59\end{array}$ & $\begin{array}{c}4654.7 \\
4.53\end{array}$ & $\begin{array}{c}3452.4 \\
2.32\end{array}$ & $\begin{array}{c}2123.9 \\
2.26\end{array}$ & $\begin{array}{c}4842.9 \\
3.65\end{array}$ & $\begin{array}{c}4400.7 \\
3.39\end{array}$ \\
\hline $\begin{array}{l}\text { \# obs. } \\
\mathbf{R}^{2}\end{array}$ & $\begin{array}{l}818 \\
0.05\end{array}$ & $\begin{array}{l}994 \\
0.06\end{array}$ & $\begin{array}{l}1417 \\
0.05\end{array}$ & $\begin{array}{l}1883 \\
0.05\end{array}$ & $\begin{array}{l}1155 \\
0.04\end{array}$ & $\begin{array}{l}1421 \\
0.07\end{array}$ & $\begin{array}{l}367 \\
0.07\end{array}$ & $\begin{array}{l}432 \\
0.05\end{array}$ & $\begin{array}{l}431 \\
0.08\end{array}$ & $\begin{array}{l}619 \\
0.04\end{array}$ \\
\hline
\end{tabular}

